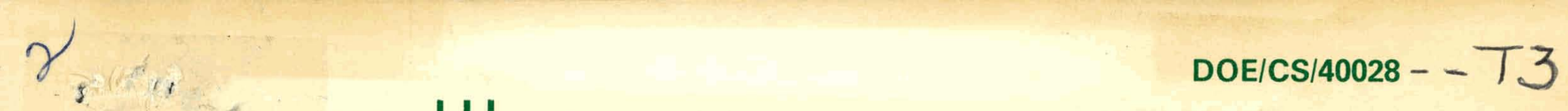

\title{
ENERGY
}

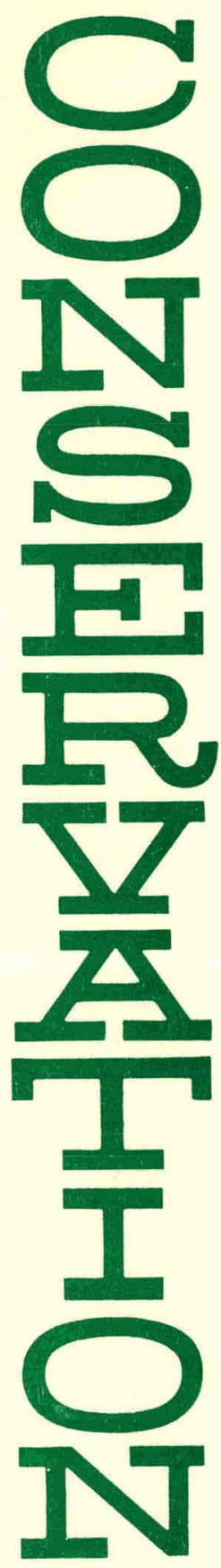

\section{LEVEL 1 ENVIRONMENTAL ASSESSMENT OF CUPOLA EMISSIONS AT THE TIOGA FOUNDRY}

K. T. Menzies

J. W. Adams

K. E. Thrun

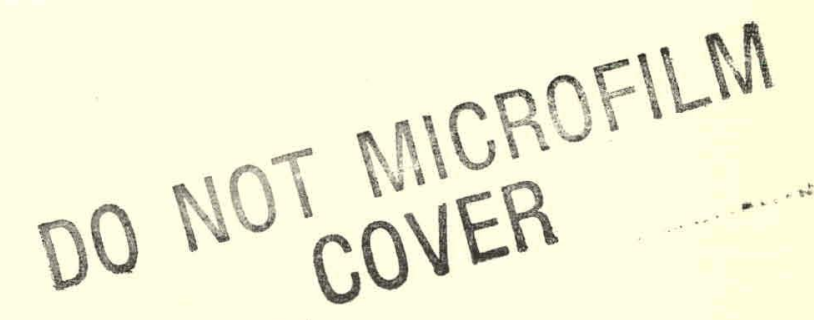

January 1984

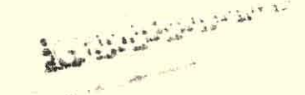

Arthur D. Little, Inc.

Cambridge, MA 02140

Prepared for

Pennsylvania State University

University Park, PA 16801

And the

U.S. Department of Energy

Under DOE Contract No. DE-AS02-76CS40028

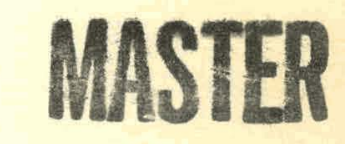

U. S. DEPARTMENT OF ENERGY IDAHO OPERATIONS OFFICE 


\section{DISCLAIMER}

This report was prepared as an account of work sponsored by an agency of the United States Government. Neither the United States Government nor any agency Thereof, nor any of their employees, makes any warranty, express or implied, or assumes any legal liability or responsibility for the accuracy, completeness, or usefulness of any information, apparatus, product, or process disclosed, or represents that its use would not infringe privately owned rights. Reference herein to any specific commercial product, process, or service by trade name, trademark, manufacturer, or otherwise does not necessarily constitute or imply its endorsement, recommendation, or favoring by the United States Government or any agency thereof. The views and opinions of authors expressed herein do not necessarily state or reflect those of the United States Government or any agency thereof. 


\section{DISCLAIMER}

Portions of this document may be illegible in electronic image products. Images are produced from the best available original document. 


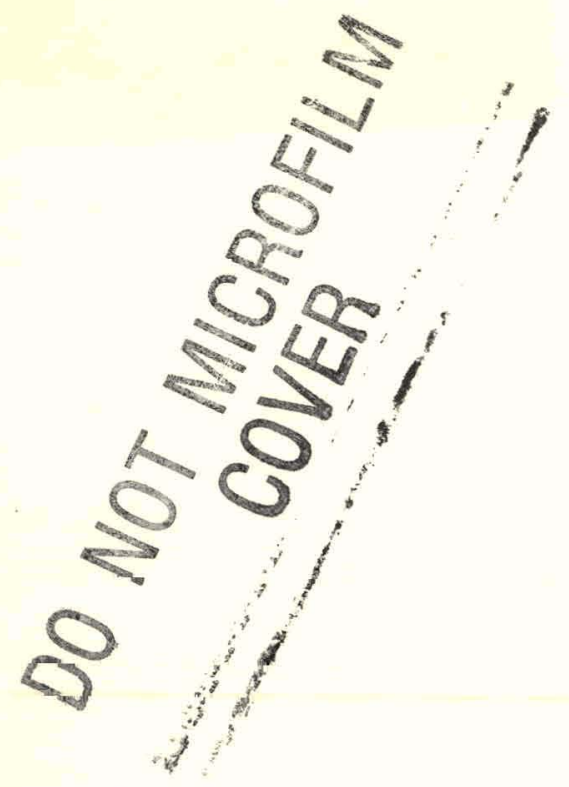

Printed in the United States of America

Available from

National Technical Information Service

U.S. Department of Commerce

5285 Port Royal Road

Springfield, VA 22161

NTIS Price Codes: Printed Copy A07

Microfiche A01

\section{DISCLAIMER}

This book was prepared as an account of work sponsored by an agency of the United States Government. Neither the United States Government nor any agency thereof, nor any of their employees, makes any warranty, express or implied, or assumes any legal liability or responsibility for the accuracy, completeness, or usefulness of any information, apparatus, product or process disclosed, or represents that its use would not infringe privately owned rights. Referercess lieieiii to any specific commorcial product, process, or service by trade name, trademark, manufacturer, or ultierwise, does not necessarily constitute or imply its endorsement, recommendation, or favoring by the United States Gnvernment or any agency thereof. The views and opinions of authors expressed herein do not necessarily state or reflect those of the United States Government ul dily ayericy thereof. 


\section{MeT!CE}

Thy

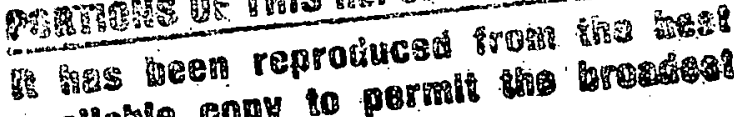

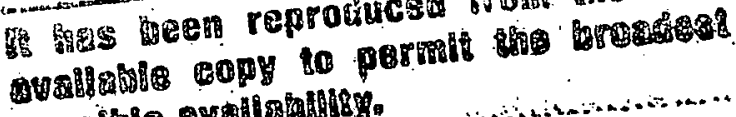

LEVEL I ENVIRONMENTAL ASSESSMENT OF CUPOLA EMISSIONS

AT THE TIOGA FOUNDRY
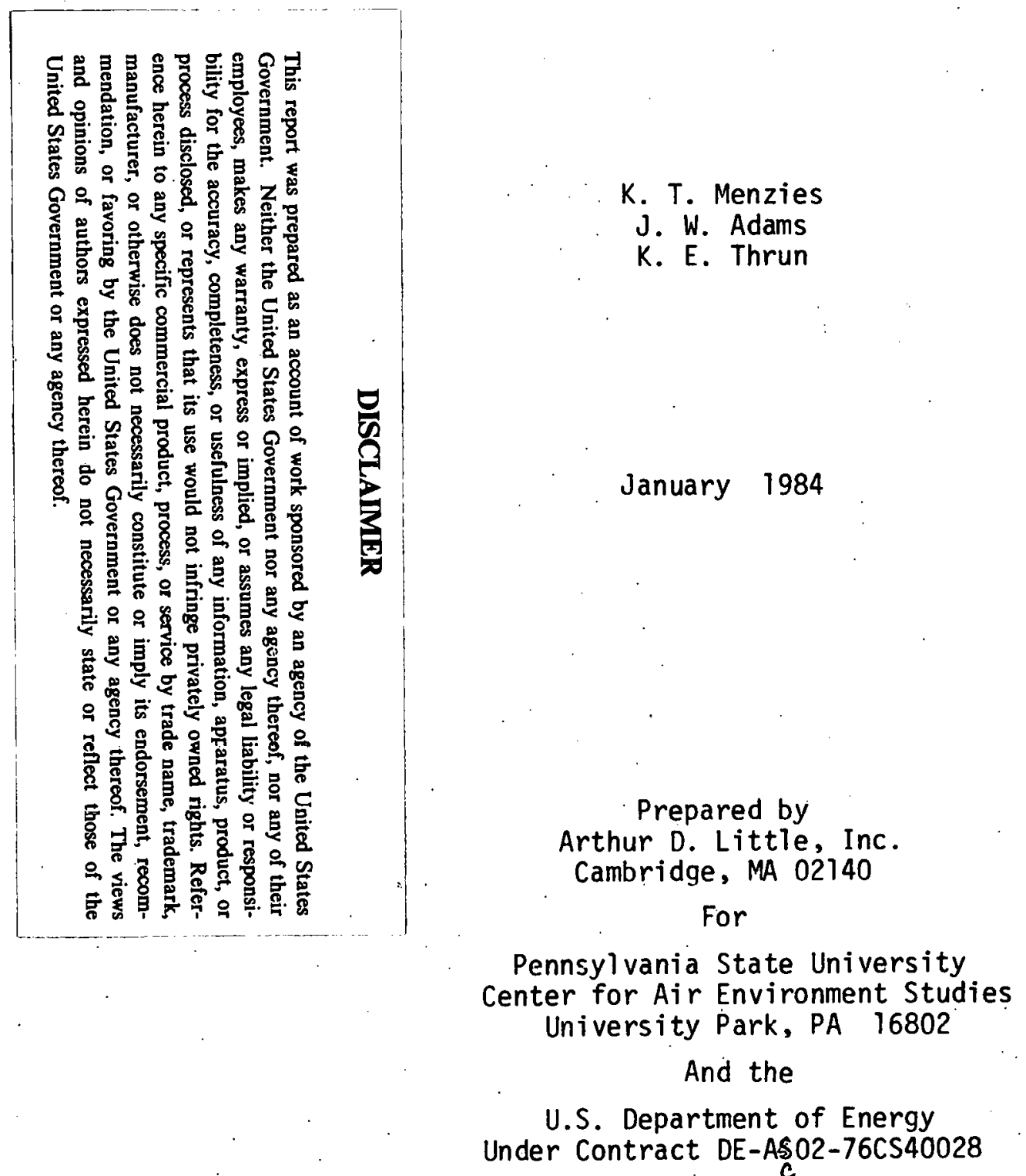

K. T. Menzies

J. W. Adams

K. E. Thrun

January 1984

Arthur D. Little, Inc.

Cambridge, MA 02140

For

Pennsylvania State University

enter for Air Environment Studies

University Park, PA 16802

And the

Under Contract DE-AS02-76CS40028

DISTRIBUTION OF THIS DOCUMENT IS UNLIMITED

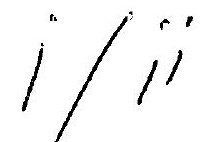


THIS PAGE

\section{WAS INTENTIONALLY \\ LEFT BLANK}


TABLE OF CONTENTS

$\underline{\text { Page }}$

List of Tables $v$

List of Figures vil

I. SUMMARY AND CONCLUSIONS $\cdot 1$

II. INTRODUCTION

III. EXPERIMENTAL PROCEDURES

A. Sampling for Comprehensive Analysis 11

B. On-Site Gas Analysis 14

C. Bag-House Samples 15

D. Analysis Procedures 15

IV. TEST RESULTS 25

A. On-Site Analysis 25

B. Results of Comprehensive Analysis 28

V. LITERATURE CITED 53

APPENDICES .

A. Level 1.-Organic Analysis Data 55

B. Spark Source Mass Spectrometry Analysis Data 107 
Table No.

Page

1

Summary of Sampling Data

26

2

Results of On-Site Gas Analyses.

27

3

Mass and Concentration of Particulates

29

4

Total Extractable Organics

32

5

Major Organic Compound Categories

38

6

Mercury in Sample Fractions

40

7

Selected Elements in Particulace Fraction

41

8

Selected Elements in Sorbent

42

9

Selected Elements in Condensate

43

10

Particle Size Distribution by Optical Microscopy 


\section{LIST OF FIGURES}

Figure No.

$\underline{\text { Page }}$

1

2

3

4

5

6

i1

12

13

14

15

Schematic Diagram of the SAA Air Flow System

Schematic Diagram of the SAA Port Locations

Level 1 Sampling and Analytical Scheme for Particulates and Gas

Method 5 Train Modified for Collection of Organic Vapors

Heat Exchanger

Procedural Steps Involved in the Level 1. Analysis of a Single Modified Method 5 Sample

Analytical Scheme for Particulate Catch

Analytical Scheme for Organic Vapors

Analytical Scheme for Volatile Metals

and Sulfur Oxides

Distribution of Low Boiling (TCO)

Organics

Distribution of High Bolling. (GRAV)

organics

Comparison of Total Organic Extractable Mass Concentrations

Particulate from Stack Ait Addition System

Particulates from Afterburner

SEM Photomicrograph of Aggregate Particulates 50 


\section{THIS PAGE}

WAS INTENTIONALLY

LEFT BLANK 
I. SUMMARY AND CONCLUSIONS

Sampling and analysis was undertaken to characterize and quantify particulate, organic and inorganic chemical concentrations in gaseous effluents downstream of an afterburner (AFB) or stack air addition (SAA) system in a cupola at the Tloga Casting Company in Owego, New York. The U.S. Environmental Protection Agency/Industrial Environmental Research Laboratory (EPA/IERL) Level 1 environmental assessment procedures (1) were used to determine if the level of pollutants present differed when using the AFB versus the SAA control device for reduction of carbon monoxide $(\mathrm{CO})$ concentrations.

Triplicate measurements made for the two control systems indicate total particulate loadings of 4.8 and $3.7 \mathrm{~g} / \mathrm{m}^{3}$ for the afterburner and stack air addition system, respectively. The difference between these values is not significant at the $95 \%$ confidence level (Student's t-test). The total organic loading was observed to be 10 and $18 \mathrm{mg} / \mathrm{m}^{3}$ for the AFB and SAA, respectively. Again, the difference is not statistically significant. However, there are some differences in the distribution of organic material among fractions, such as compounds with bolling points between $100^{\circ}-300^{\circ} \mathrm{C}$, that do appear to be significant based on the t-test. Also, the bag-house particulate samples collected downstream of the SAA were black, while those collected from the AFB effluent were gray. These findings tend to indicate a slightly greater organic loading in the effluent from the SAA, but the difference is similar in magnitude to the factor of two uncertainty assoclated with the Level 1 sampling and analysis protocols used in this ștudy.

Microscopic examination revealed that the particulate matter present in the cupola effluent consists malnly of silicates. The mass concentration of trace metals in the particulate, as measured by spark source mass spectrometry, is not significantly different during operation of the afterburner and stack air addition system. The concentration of elements 
designated as hazardous air pollutants (2), i.e., beryllium and mercury, is not significantly different during operation of the two control systems.

Major organic compound classes present during operation of both the afterburner and stack air addition control systems include: (1) aliphatic hydrocarbons of molecular weight up to and exceeding 450, (2) polycyclic aromatic hydrocarbons ( $\mathrm{PAH}$ ) of molecular weight less than 216, and (3) carboxylic acids such as benzolc acid. Of these, the polycyclic aromatic hydrocarbons might seem to be of most interest in terms of potential implications for health, since some compounds of this type are suspect cancer agents. However, most of the polycyclic aromatic hydrocarbons present have fewer than five fused rings and are not suspected carcinogens. Higher molecular weight polycyclic aromatic hydrocarbon specles, including some of those suspected of carcinogenic activity, might also be present at lower concentrations. The low resolution mass spectrometric (LRMS) data indicate that the total PAH content is somewhat lower for the stack air addition system than for the afterburner.

For both control systems, the LRMS data indicate that aliphatic hydrocarbons are relatively more abundant than polycyclic aromatic hydrocarbons. The same data indicate a higher relative concentration of aliphatic hydrocarbons with the stack air addition system. Although aliphatic hydrocarbons of high molecular welght, e.g., MW $>360$, are not suspect carcinogens, they may be promoters. Their relative abundance may, therefore, be important.

During operation of the stack ait addition system, a higher mass concentration of organic compounds, in the bolling range of $100^{\circ}-300^{\circ} \mathrm{C}$, was observed than during operation of the afterburner. The possible health implications of these observations are uncertain, especially since the difference in concentrations is small compared to the variance expected from the sampling and analysis procedures. 
Thus, the differences in organtc mass concentration and chemical character observed between the afterburner and stack air addition system may or may not be significant from a health aspect. The magnitude of the quantitative differences in mass concentrations of organic matter is not large (i.e., less than a factor of two) and is near the magnitude of precision associated with the analytical procedures used in this work. Qualitative differences, 1.e., lower abundance of polycyclic aromatic hydrocarbons and higher abundance of aliphatic hydrocarbons, are not large on a subjective basis and any synergistic impact is uncertain. The small differences between organic compound concentrations and character during operations of the two control systems would indicate that they are also likely to be comparable in terms of potential health impact. It is possible that compound-specific analysis of the cupola effluent might indicate some exceptions to this general statement by revealing more substantial differences in levels of emissions of individual organic species.

Combustion gases are present in statistically simflar concentration levels ( $95 \%$ confidence) during operation of the AFB and SAA. Carbon monoxide appears to be oxidized to carbon dioxide with comparable efficiency by either control system.

In summary, the concentration of partial combustion gases, e.g., carbon monoxide, nitrogen oxides, and hydrocarbons, are equivalent during operation of the afterburner and stack alr addition system. Inorganic particulates account for about $95 \%$ of the total mass of material collected from the cupola effluent under both conditions. The mass concentration of total particulates and selected elements, e.g., trace metals, is equivalent during the use of elther control device.

The mass concentration of total organic extractable matter is not significantly different during operation of the stack air addition system or the afterburner. However, for organic compounds with bolling points between $100^{\circ}$ and $300^{\circ} \mathrm{C}$, the mean mass concentration is about a factor of two greater for the SAA than the AFB. This is a significant 
difference at the $95 \%$ confidence level, but not at the $99 \% 1$ level. The health impact of these differences is uncertain but on the basis of the prectsion of the experimental data and current understaiding of risk assessment for complex effluents, the two systems appear to be comparable in emissions and probable 1mpact on health and the environment. 


\section{II.' INTRODUCTION}

In the spring of 1981, a stack air addition system (SAA) was installed on the 40-inch divided blast cupola at the Tioga Foundry in Owego, New York. The stack air addition system consists of two rings, seven and nine feet below the charge door sill, with four equally spaced ports in each ring offset from one another; air is provided to the ports by a Roots blower capable of an $850 \mathrm{scfm}$ flow rate. The lower ring is 10'6". above the lower tuyeres. Flow rates are monitored using annubars and water manometers. A schematic diagram of the system is shown in Figure 1 and the locations of the ports in the cupola shell in Figure 2.

The SAA was installed in partial fulfillment of the terms of a research contract ("kDE-AS02-76CS40028), conducted by the Pennsylvanla State Unfversity, which has as its goals to:

1. Develop methods for eliminating afterburners from production cupolas;

2. Improve cupola operating efficiency;

3. Transfer this technology to the foundry industry.

Field and laboratory studies indicated that, by Introducing air at the proper point in the cupola shell, carbon monoxide can be ignited and burned to carbon dioxide in the stack. Thus, the afterburner may be eliminated and a reduction in the amount of energy required for melting a unit of 1ron achieved.

A necessary input to this program is a demonstration that the change in technology does not have an adverse effect on air quality. To achieve this goal, Arthur D. Ifttle, Inc. conducted an environmental assessment of the stack emissions from the cupola. For these tests, EPA/IERL Level 1 environmental test procedures (1) were used. 


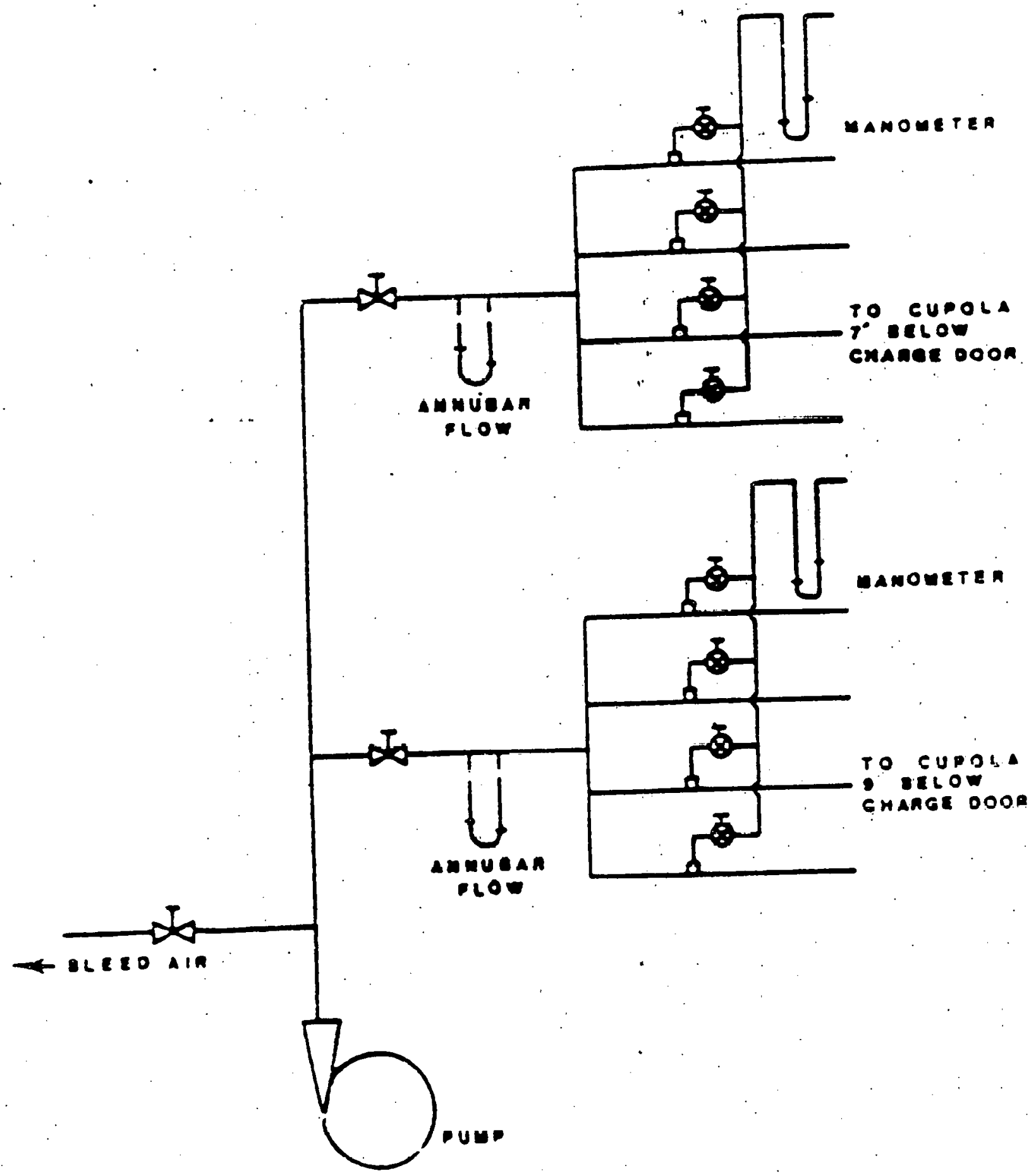

FIGURE 1. SCHEMATIC DIAGRAM OF THE SAA AIR FLOW SYSTEM

Source: Reference 12 

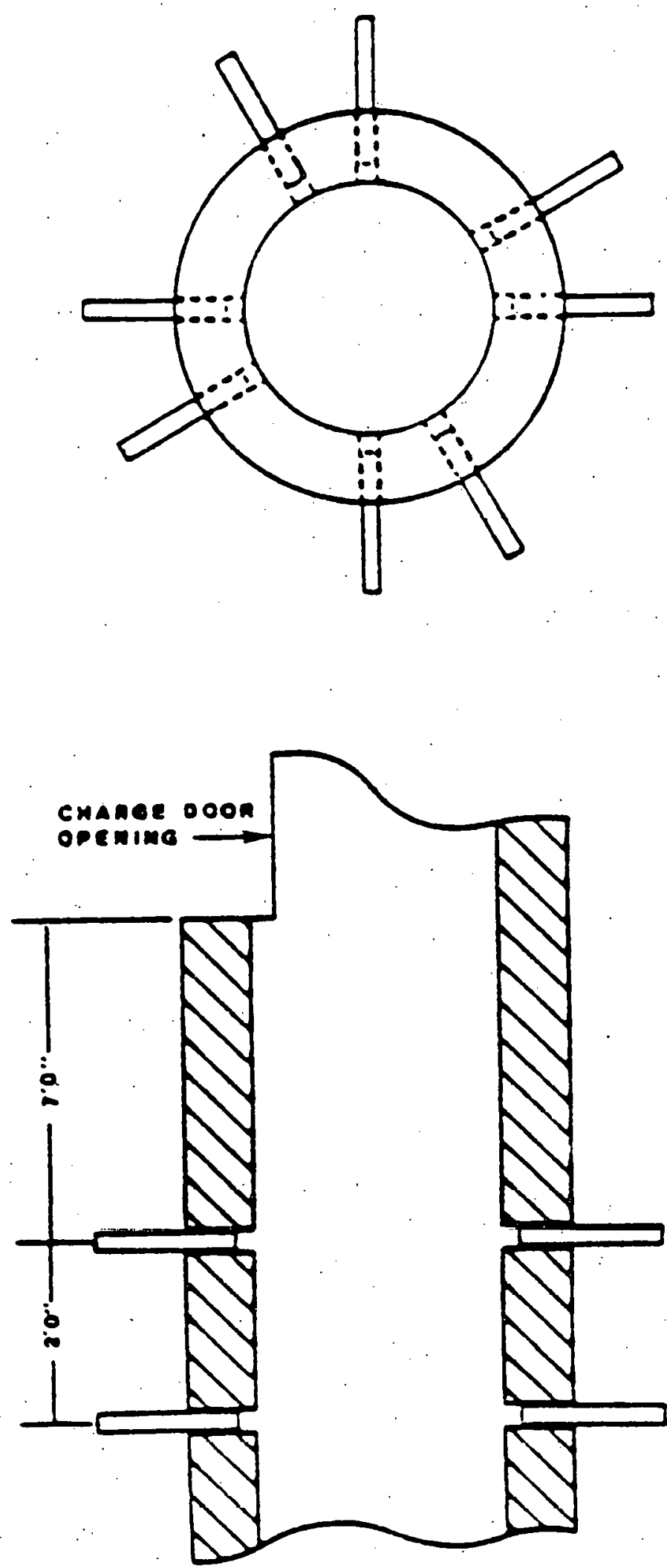

FIGURE 2. SCHEMATIC DIAGRAM OF THE SAA PORT LOCATIONS

Source: Reference 12 
Samples of gaseous effluent from the cupola were collected downstream of the afterburner or the stack air addition system depending upon the test conditions being sampled, and upstream of emission control devices. The test consisted of triplicate collections of:

1. The gaseous effluent during cupola operation with the af terburner, and

2. The gaseous effluent during cupola operation with the stack air addition system.

The samples collected with a Modified Method 5 (MMS) train were analyzed by EPA/IERL Level 1 procedures. Figure 3 shows a schematic diagram of the Level 1 analytical scheme. For the purposes of this program, all of the particulate catches were combined prior to analysis. Both organic and inorganic species were analyzed via the appropriate Level 1 procedures. Spark source mass spectrometry was used to survey the inorganic species from lithlum (LI) to uranium (U) except for volatile inorganics, mercury $(\mathrm{Hg})$, antimony $(\mathrm{Sb})$, and arsenic (As), which were determined by atomic absorption spectrometry. Infrared spectrometry and low resolution mass spectrometry were used to identify and characterize the organic components of the collected samples. In addition to the Modified Method 5 samples, concentrations of combustion gases, 1.e., carbon dioxide $\left(\mathrm{CO}_{2}\right)$, carbon monoxide $(\mathrm{CO})$, nftrogen oxides $\left(\mathrm{NO}_{x}\right)$, oxygen $\left(\mathrm{O}_{2}\right)$ and hydrocarbons (HC) were measured during sample collection.

The actual tests were conducted during the weeks of September 14 and 21 , 1981. On September 15, 16, 17, and 21, the foundry operated with a natural gas-fired af terburner; on September 22, 23, and 24 only the stack alr addition system was in operation. 


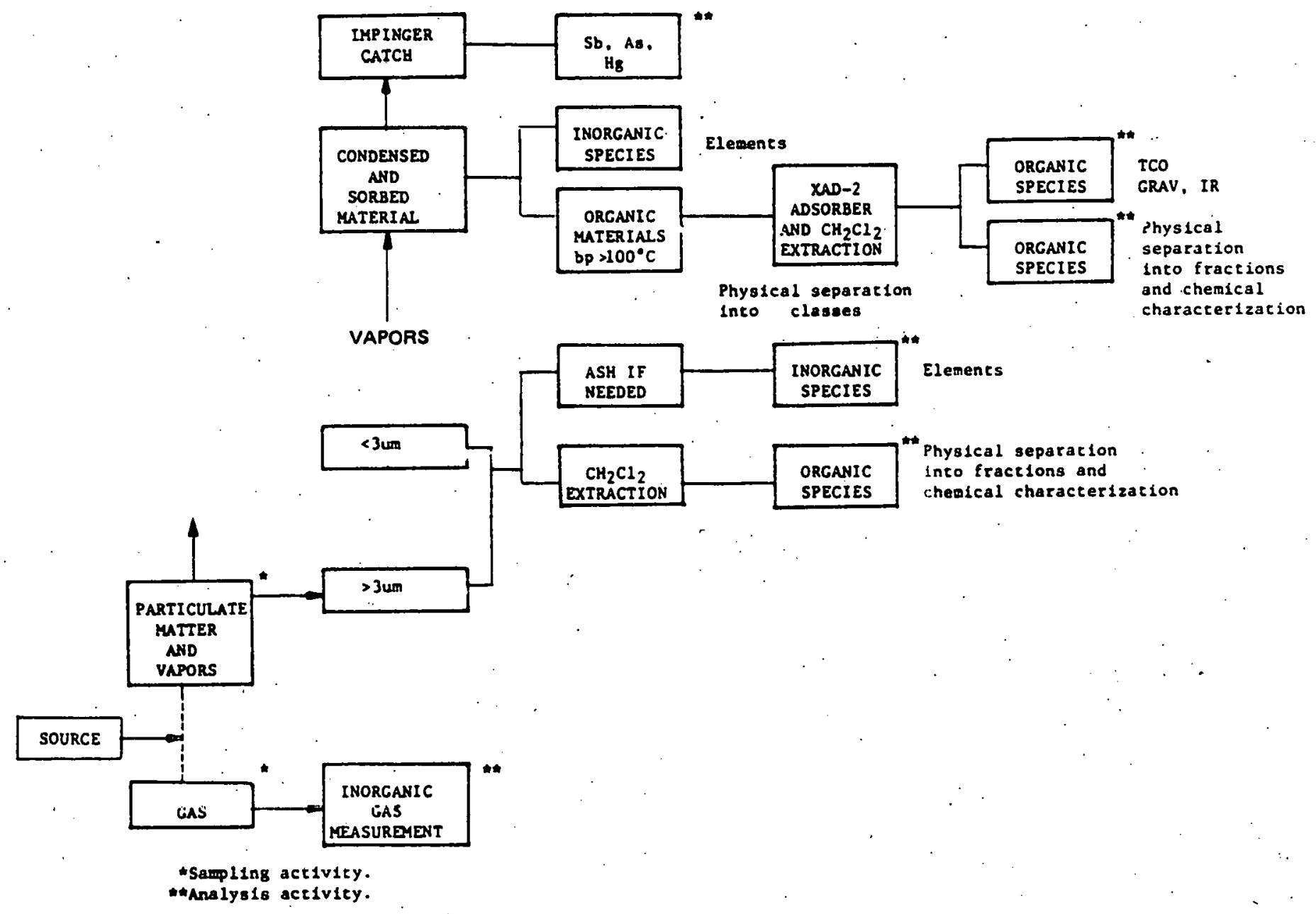

FIGURE 3. LEVEL I SANPIING AND ANALYTICAL SCHEME FOR PARTICULATES AND GASES

Source: Reference $\underline{1}$

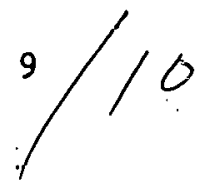


THIS PAGE

WAS INTENTIONALLY

LEFT BLANK 


\section{EXPERIMENTAL PROCEDURES}

\section{A. SAMPLING FOR COMPREHENSIVE ANALYSIS}

The objectives of this test program include quantitative estimation of total particulate matter concentrations and comprehensive characterization of organic and inorganic materials present. To accomplish this task, samples were collected using a Modified Method 5 train (MM5), shown schematically in Figure 4. This sampling train incorporated a water-cooled, quartz-lined, stainless steel probe; a heated cyclone and filter; a heat exchanger; sorbent trap; condensate trap and impinger train. The probe was water-cooled so as to reduce the temperature of the stack gas $\left(800^{\circ}-1100^{\circ} \mathrm{C}\right)$ to about $120^{\circ} \mathrm{C}$ prior to passage into the cyclone and filter oven. The cyclone was used upstream of the filter to limit potential overloading of the filter. In order to cool the gas stream to a temperature (i.e., $20^{\circ} \mathrm{C}$ ) consistent with efficient collection of organic vapors on the XAD-2® sorbent trap, a heat exchanger (Figure 5) was installed upstream of the solid sorbent trap. The heat exchanger was fabricated from a glass condenser and cold finger through which water from the 1mpinger ice bath was circulated with a peristaltic pump. A thermocouple was installed in a glass tip in the gas stream to monitor the temperature of the gas entering the sorbent trap.

An impinger train containing six 500 milliliter Impingers was installed downstream of the sorbent trap. An empty impinger was used for collection of condensate from the sorbent trap. Two oxidizing impingers containing hydrogen peroxide for removal of acid gases were followed by two oxidizing impingers containing ammonium persulfate and silver nitrate to collect volatile metals, 1.e., mercury, antimony and arsenic. A sixth impinger containing silica gel was used to dry the air prior to volume measurement in a dry gas meter. 


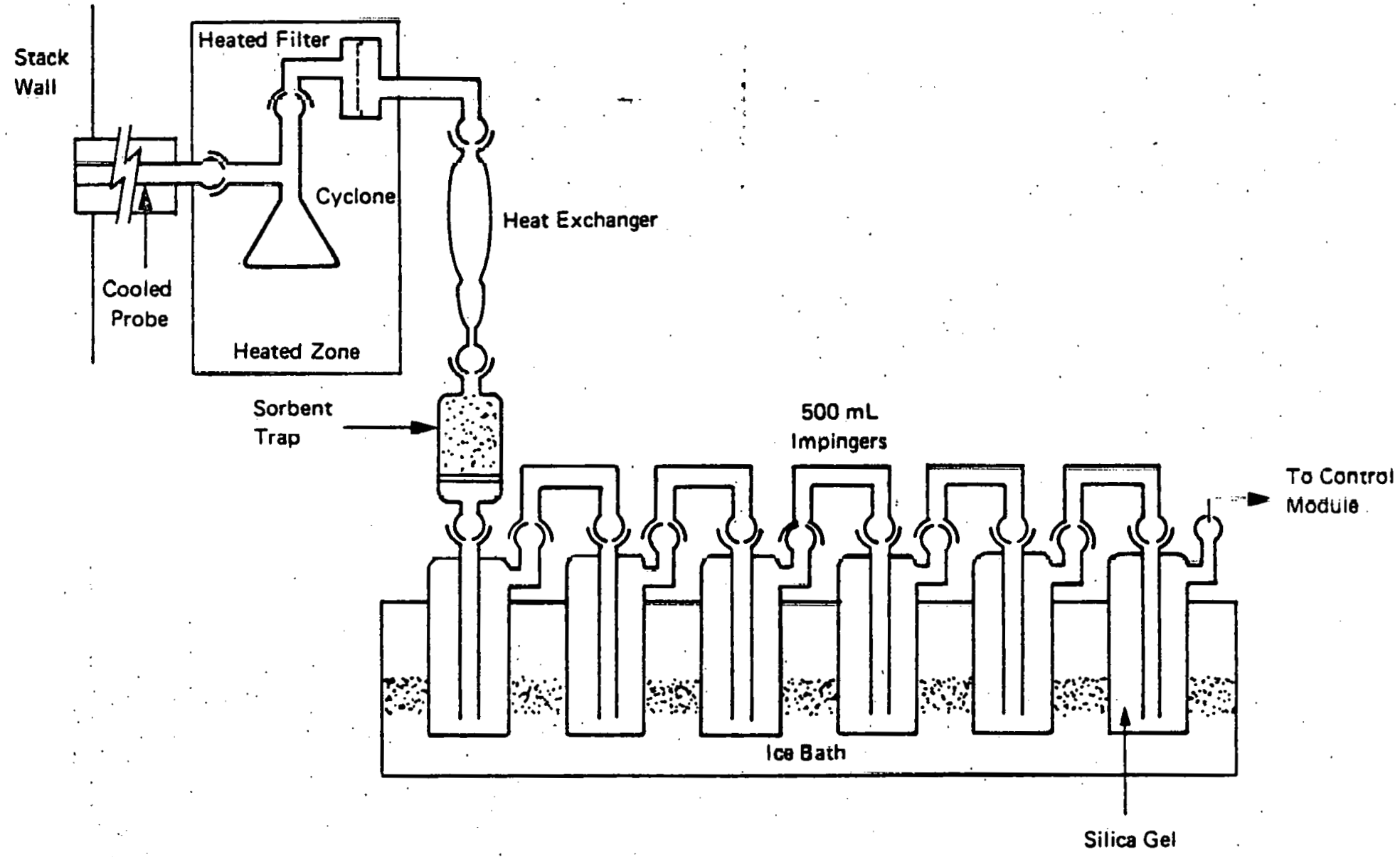

FIGURE 4 METHOD 5 TRAIN MODIFIED FOR COLLECTION OF ORGANIC VAPOAS 


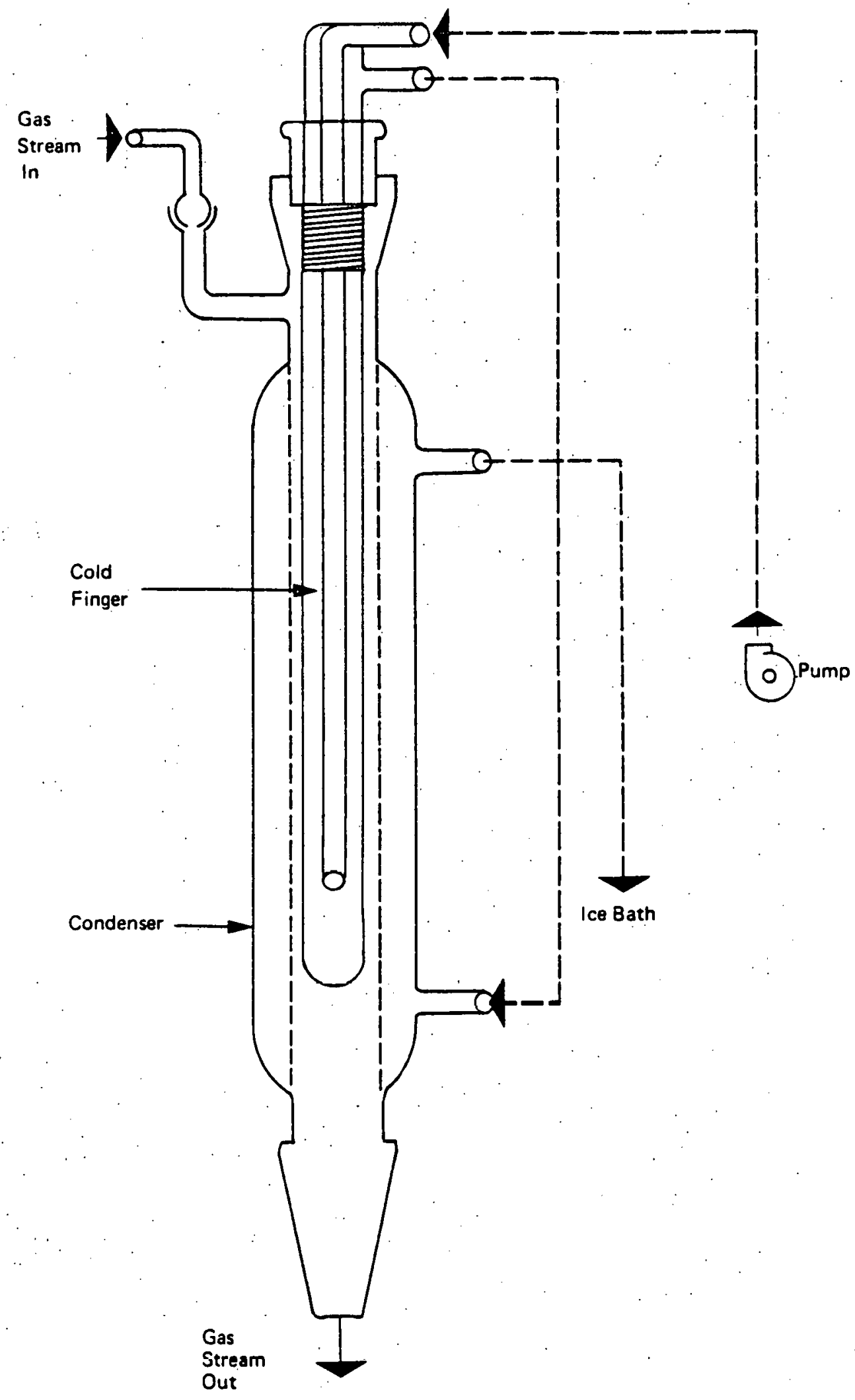

FIGURE 5 HEAT EXCHANGER 
During sampling, the probe nozzle was positioned in the stack at a fixed point of average velocity, determined by a preliminary traverse with a pitot tube according to EPA Method 2 (3). The sampling system was operated as close to isokinetic conditions as was possible within the constraints of avallable nozzle sizes and operating parameters. Approximately $3-5 \mathrm{~m}^{3}$ of gas (STP) were collected during each test at a flow rate ranging from 15-30 ifters per minute.

At the completion of each sampling run the train was disassembled and samples recovered according to Level 1 procedures (1). The residue from the probe was recovered with a nylon brush and flushed with equal volumes of HPLC-grade methanol and dichloromethane. The residue in the cyclone and front half of the filter holder was rinsed with the same solvent into the glass bottle containing the probe rinse. Individual filter samples were placed in petri dishes for transport. The solvent rinse from the back half of the filter holder, heat exchanger and condensate trap were collected in a separate glass bottle. The sorbent trap was sealed with Teflon film for transportation. The two $\mathrm{H}_{2} \mathrm{O}_{2}$ impinger samples and rinses were placed in a common glass bottle. The ammonium persulfate/silver nitrate impinger samples and rinses were also comblned in a separate glass bottle. The silica gel was transferred to a tared nalgene bottle for subsequent analysis of percent moisture according to EPA Method 4 (3).

\section{B. ON-SITE GAS ANALYSIS}

1. Carbon Monoxide (CO), Nitrogen Oxide (NO $x$ and Total Hydrocarbons (HC)

The gas sampling train consisted of a $3 / 8^{i \prime-O D ~ p o r c e l a i n ~ p r o b e ~ i n s e r t e d ~}$ into the stack; a $75-\mathrm{ft}$ long, heat-traced $\left(100^{\circ} \mathrm{C}\right)$ Teflon line; a heated $\left(175^{\circ} \mathrm{C}\right)$ oven containing a metal bellows pump and glass fiber filter; and instrumental analyzers for measurement of $\mathrm{CO}$, $\mathrm{NO}_{\mathrm{x}}$ and $\mathrm{HC}$, 1.e., Beckman 864, Beckman 955 and Beckman 402, respectively.

After exfting the oven, the gas stream entered a heat-traced manifold which split the flow to the $\mathrm{NO}_{x}$ and HC analyzers. Excess gas was 
collected in a Tedlar ${ }^{\oplus}$ bag over a period of 10 minutes and, after cooling, was pumped through sillca gel and into the $C O$ analyzer for measurement of concentration.

\section{Orsat Device}

An Orsat device was used to collect and analyze stack gas for $\mathrm{O}_{2}, \mathrm{CO}_{2}$ and $\mathrm{CO}$ on an infrequent basis. Samples were also collected from the stack (through the pitot tube on the probe) and at the continuous analyzer manifold to check for leaks, confirm the accuracy of the gaseous analyzers, and to compare with concentrations measured independently by a Pennsylvania. State University fleld team.

\section{BAG-HOUSE SAMPLES}

Grab samples of the particulate removed from the cupola stack in the bag-house were collected during operation of the cupola with the afterburner and with the stack air addition system. These two samples were stored in glass bottles for possible future analysis.

\section{ANAIYSIS PROCEDURES}

The MS train samples collected in the fleld were stored in ice and returned on a weekly basis to the laboratories of Arthur D. Little, Inc. fur analysis. The samples réceived for analysis included six components from each sampling run and two solvent blanks corresponding to the solvents used for extraction of the sorbent, condensate, and for probe and cyclone rinses. Each sample was subjected to the Level 1 analytical program, including Inorganic and organic analysis. Figures 6-9 show the actual step-by-step analysis scheme used for each sample. All samples were carried through the entire Level 1 program except in those cases where the sample size and concentration was below that required for further analysis. Only two sorbent samples contained sufficlent material to warrant fractionation by liquid chromatography. 


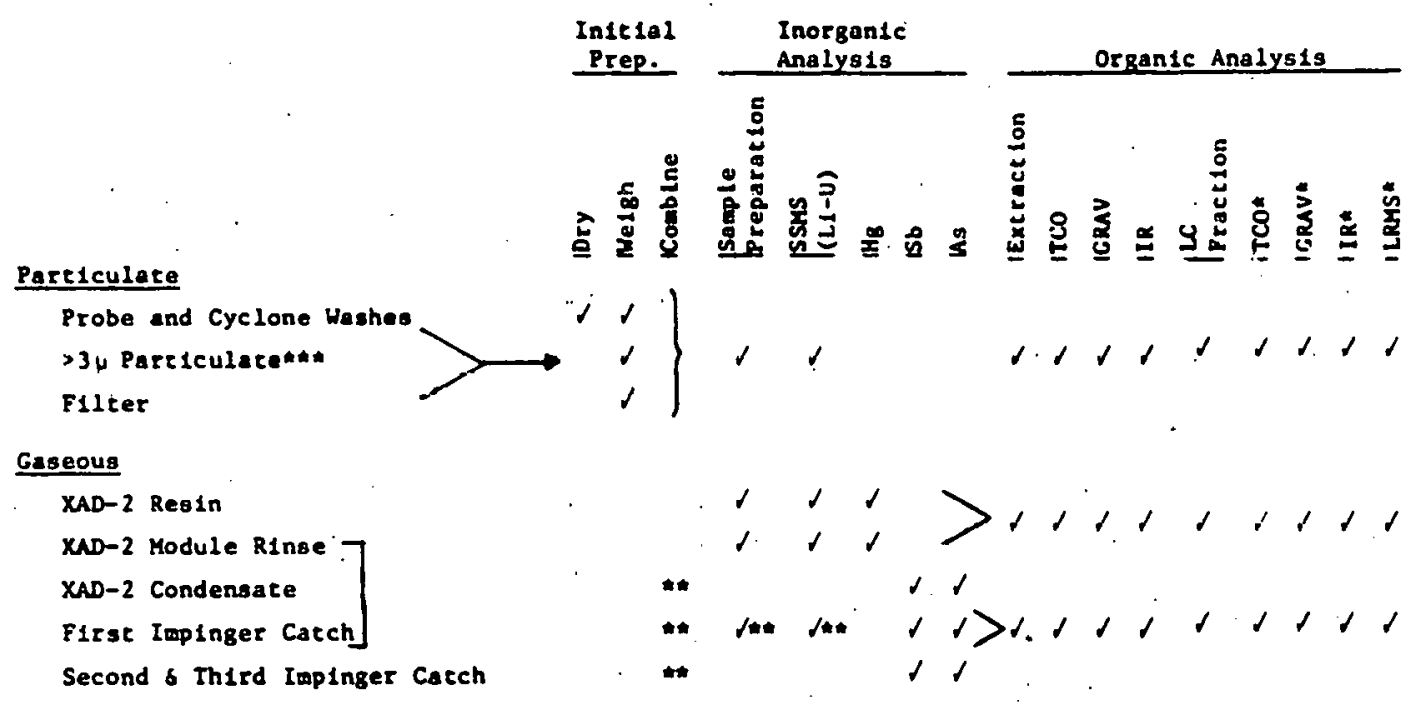

Step performed on each of the LC fractions.

* Combined allquors for Inorganic analysis by SSHS.

*HWDe to the large awount of particulace present in cupola gaseous effiuent. a knockdoun stage with an approximacely 3 c cutoff w11l be added to the modified Method 5 train prior to the filter.

Brackets Indicate combined fractions.

FIGURE - 6. PROCEDURAI STEPS INVOLVED IN THE LEVEI 1 ANALYSIS OF A SINGLE MODIFIED METHOD 5 SANIPLE 


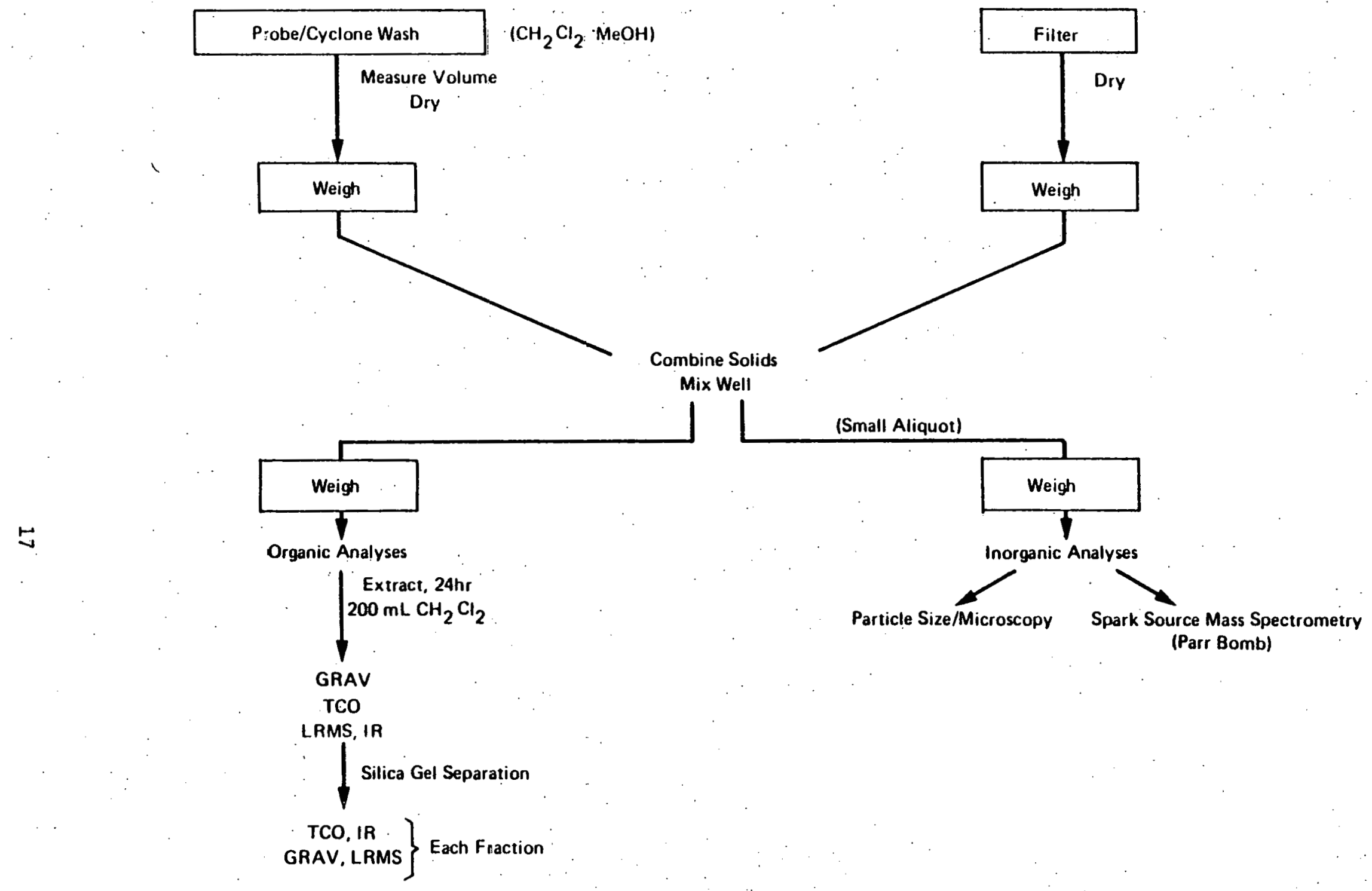




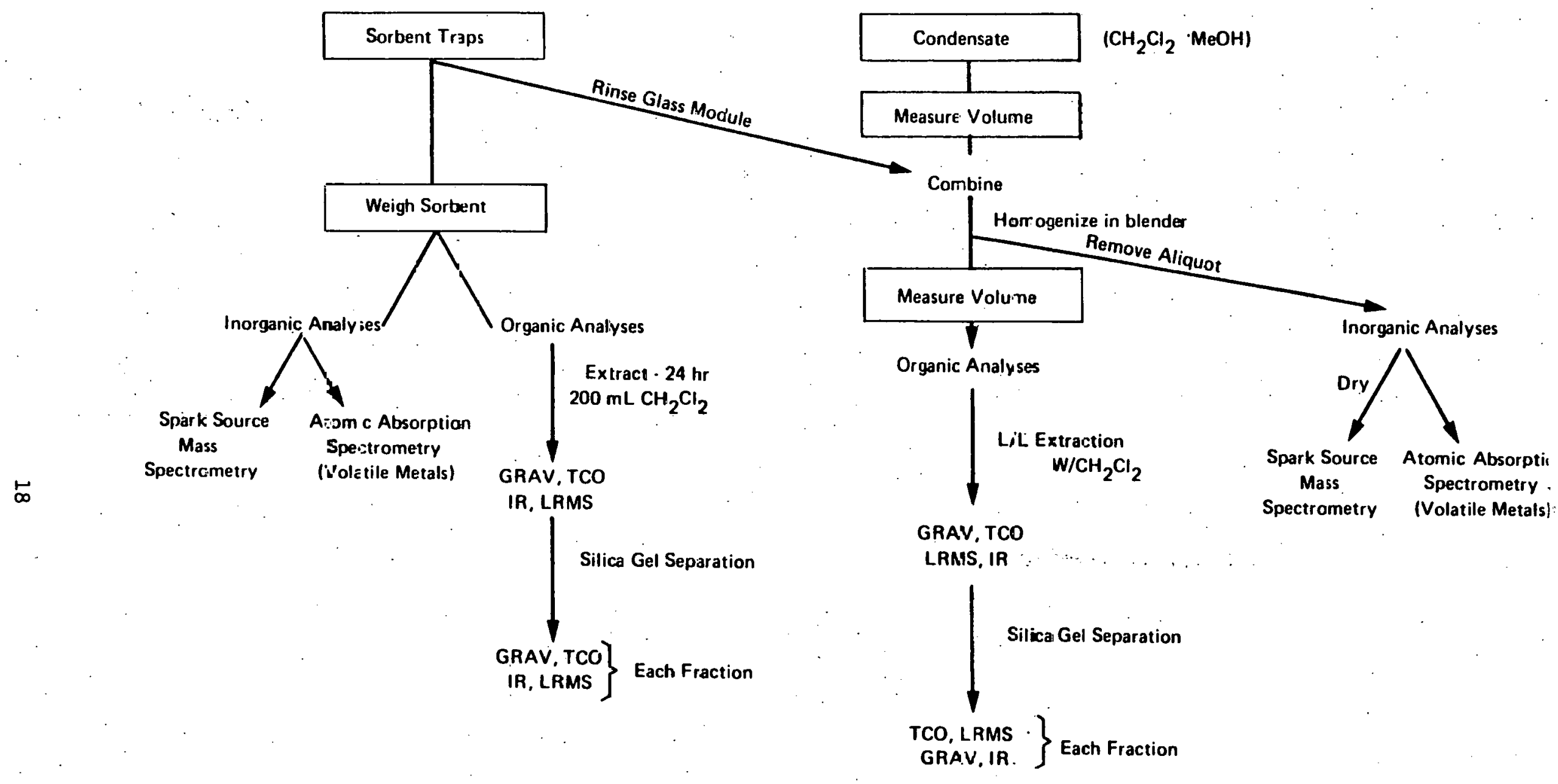

FIGURE 8 ANALYTICAL SCHEME FOR ORGANIC VAPORS 


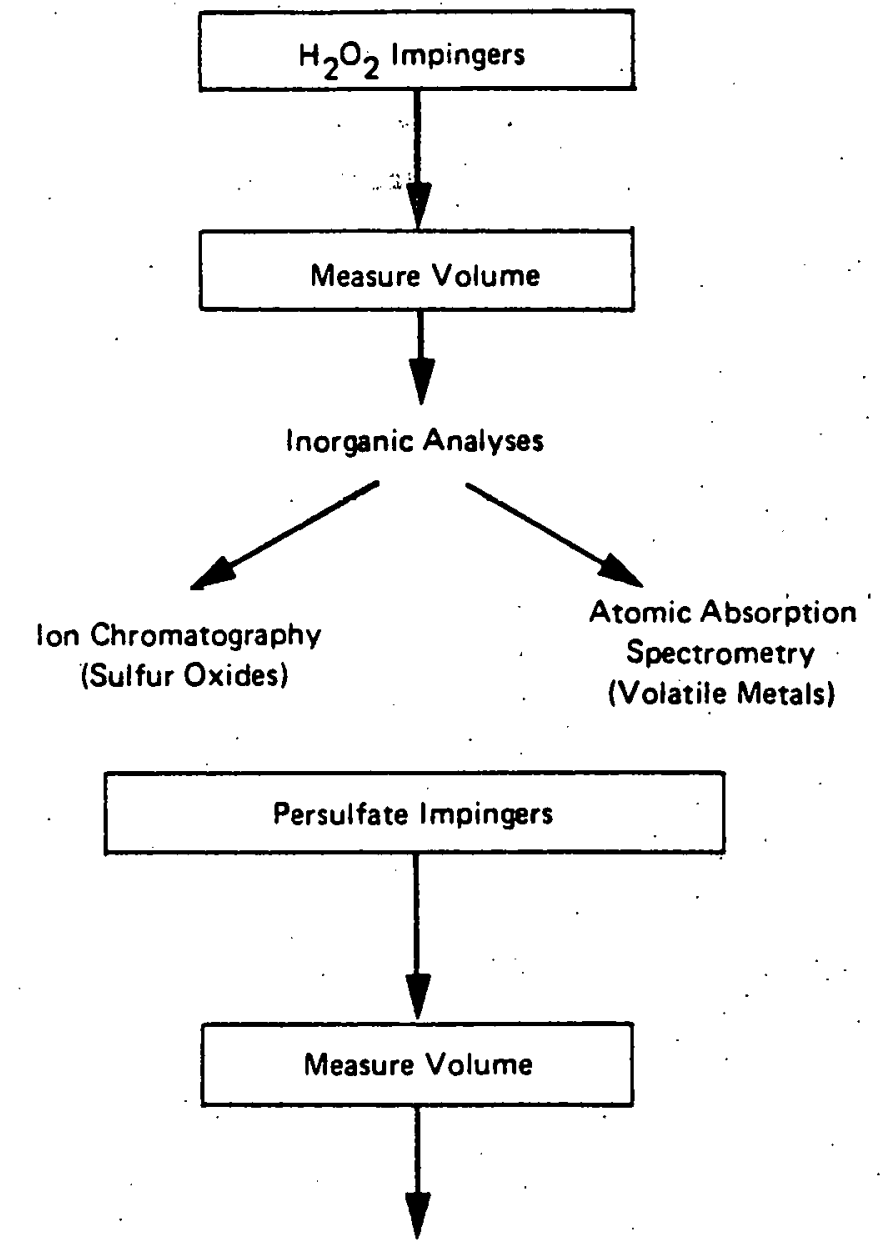

Atomic Absorption Spectrometry

(Volatile Metals)

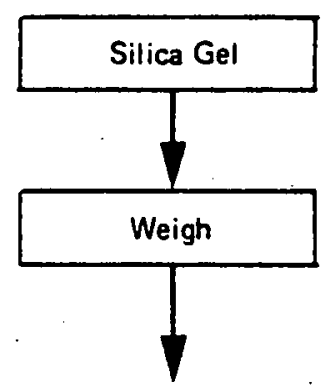

Moistu. e Content

FIGURE 9 ANALYTICAL SCHEME FOR VOLATILE METALS AND SULFUR OXIDES 


\section{Level I Organic Analysis}

Level 1 organic analysis procedures as described in the EPA procedures manuals (1) were followed. A brief summary of the various steps is given below.

\section{(a) Particulate Masses}

The masses of the particulate samples (filter and cyclone catches; probe; cyclone rinses) were obtained by drying the samples to constant weight $( \pm 0.1 \mathrm{mg})$ in tared evaporating dishes at $50^{\circ} \mathrm{C}$ and cooling to room temperature lin a desiccator.

\section{(b) Soxhlet Extraction}

All extractions were carried out for a 24-hour period using high-purity methylene chloride (Fisher Scientific, Inc., HPLC-grade). The following procedures were used:

- XAD-2 ${ }^{\circledR}$ Resins - Extracted with 200 mL of methylene chloride.

- Probe, cyclone catches and filter sample - Weighed individually and then combined. Portions of the nombined particulates were repuved for microscopy and inorganic analysis and the remainder extracted with $200 \mathrm{~mL}$ of methylene chloride.

\section{(c) Total Chromatographable Organics Analysis (TCO)}

The quantity of the total organic material with bolling point in the range of $100-300^{\circ} \mathrm{C}$. was determined by gas chromatography "sing a flamo ionization detector. The concentration of each sample was calculated from the ratio of the peak areas of the sample to that of the known 
standards. The following instrument conditions were used:

$\begin{array}{ll}\text { Column: } & 10 \% \text { oV-101 on } 100 / 120 \text { mesh Supelcoport } \\ \text { Injector Temperature: } & 270^{\circ} \\ \text { Detector Temperature: } & 305^{\circ} \mathrm{C} \\ \text { Temperature Program: } & \text { Room temperature for } 5 \text { minutes, then pro- } \\ & \text { gramed at } 20^{\circ} \mathrm{C} / \mathrm{min} \text { up to } 250^{\circ} \mathrm{C} \\ \text { Carrler Gas Flow: } & \text { Helium at } 30 \mathrm{~mL} / \mathrm{min}\end{array}$

(d) Gravimetric Analysis (GRAV)

The quantity of organic materlal with a bolling point higher than $300^{\circ} \mathrm{C}$ was determined by the gravimetric analysis method (GRAV). One to five ml aliquots were pipetted into precleaned, dried and weighed aluminum dishes, and were dried at room temperature in a desiccator to constant weight $( \pm 0.1 \mathrm{mg})$.

\section{(e) Infrared (IR)}

The IR spectra of all samples were obtalned on a Digilab 15C FTIR spectrometer, using potassium bromide plates. Spectra were interpreted with the aid of References $4-\underline{7}$.

\section{(f) Lizuid Chromatographic (LC) Separation}

Samples for liquid chromatography were initially concentrated to $10 \mathrm{~mL}$ using a Kuderna-Danish apparatus followed by concentration to $1 \mathrm{~mL}$ under a nitrogen stream and then subjected to three consecutive solvent exchanges with cyclopentane. The resultant cyclopentane solutions were introduced onto a silica gel column, and seven fractions were collected by elution with solvent mixtures of increasing polarity. Fractions 2 and 3 were combined, as were Fractions 4 through 7. 


\section{(g) Low Resolution Mass Spectrometry (LRMS)}

LRMS analysis was carried out on a Dupont 21-110B mass spectrometer. Both batch inlet and direct insertion probe techniques were used depending on the TCO content of the samples. Sample sizes varied from $20^{\circ} \mu \mathrm{L}$ to $50 \mu \mathrm{L}$. Typically, a sample was run at $15 \mathrm{eV}$ and $70 \mathrm{eV}$ Ionization potentials over a temperature of $70-350^{\circ} \mathrm{C}$. Interpretation of the mass spectra was based on References $\underline{8}-\underline{11}$.

\section{Level 1 Inorganic Analys1s}

Elemental analysis was performed on each sample after the appropriate sample preparation (described below), using a JOEL Spark Source Mass Spectrometer and photographic detection system. These analyses were conducted by GCA Corporation; Technology Division.

\section{Sample Preparation}

Particulates: Mixed with carbon to form an electrode $\mathrm{XAD}-2^{\circledR}$ resin: Parr Bomb combustion over nitric acid

Arsenic, mercury and antimony in impingers were determined by atomic absorption spectroscopy. A Perk1n-Elmer 503 Spectrophotometer was used.

\section{Microscopic Analysis}

A particulate sample from one MMS train sample from each control system was examined under a standard polarizing microscope. Photomicrographs were made on Ektachrome High Speed film, with samples immersed in a medium of 1.44. index to provide good contrast. Additional samples were examined by scanning electron microscopy. 


\section{Sulfur Oxides Analysis}

Aliquots of impinger samples were analyzed by 1on chromatography using a Dionex Mode1 14. Samples were analyzed using the following conditions:

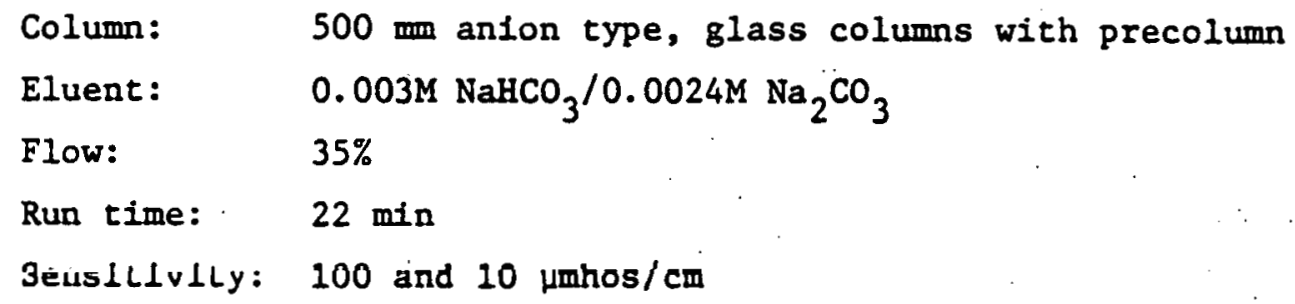

All samples were diluted by a factor of ten prior to analysis so that solutions injected on the column contained a maximum of $3 \%$ hydrogen. peroxide. 


\section{THIS PAGE \\ WAS INTENTIONALLY \\ LEFT BLANK}




\section{TEST RESULTS}

\section{A. ON-SITE ANALYSES}

As noted previously, individual Modified Method 5 (MM5) samples were collected on each of seven days during the weeks of September 15 and September 22, 1981. Four samples were collected from the stack (on September 15, 16,17, and 21, 1981) when the cupola was operating with the afterburner (AFB). Three samples were collected on September 22-24, 1981 when the cupola was operating with the stack air addition system (SAA).

Table I summarizes the sampling data acquired during the seven runs. Run 1 was the first collection conducted on the cupola. Due to minor system malfunctions, e.g.; leaks, and the realization that future runs would benefit from this experience and familiarity with the interaction of the sampling train and the high temperature environment, this run was discarded. Samples from other runs were analyzed in accordance with Level 1 procedures (1). The low volume of gas collected during Run 5 is due to a significant leak which occurred during sampling. This problem was noted in the field, resolved, and the fleld data satisfactorily corrected by careful analysis of temperature and pressure drop data. Run 5 samples were, therefore, analyzed and the data included in this Lepuil.

Table 2 summarizes the results of the on-site analyses of stack gases. Due to the large variability in concentrations observed for the three gases which were monitored with instrumental analyzers (i.e., carbon monoxide, nitrogen oxides, and hydrocarbons), the observed differences in concentration for these gases with the afterburner or stack air addition system are not statistically significant. Observation of operation of the cupola during daily sampling and analysis indicates that short-term variation in scrap metal charging rate and blower operation dramatically influenced the concentration of these partial combustion gases. This variation is 1llustrated by the range of temperature observed during a run. 
TABLE 1

SUMMARY OF SAMPLING DATA

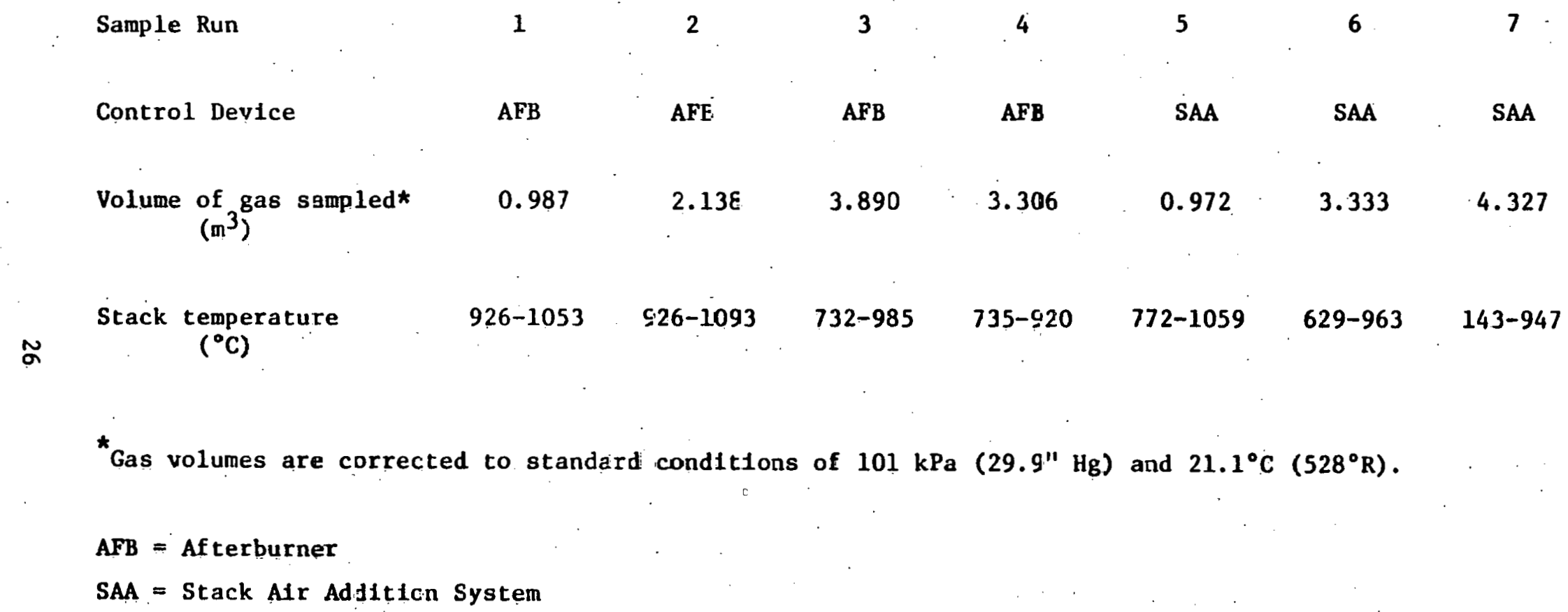


TABLE 2

RESULTS OF ON-SITE GAS ANALYSES

(Concentration, ppmv)

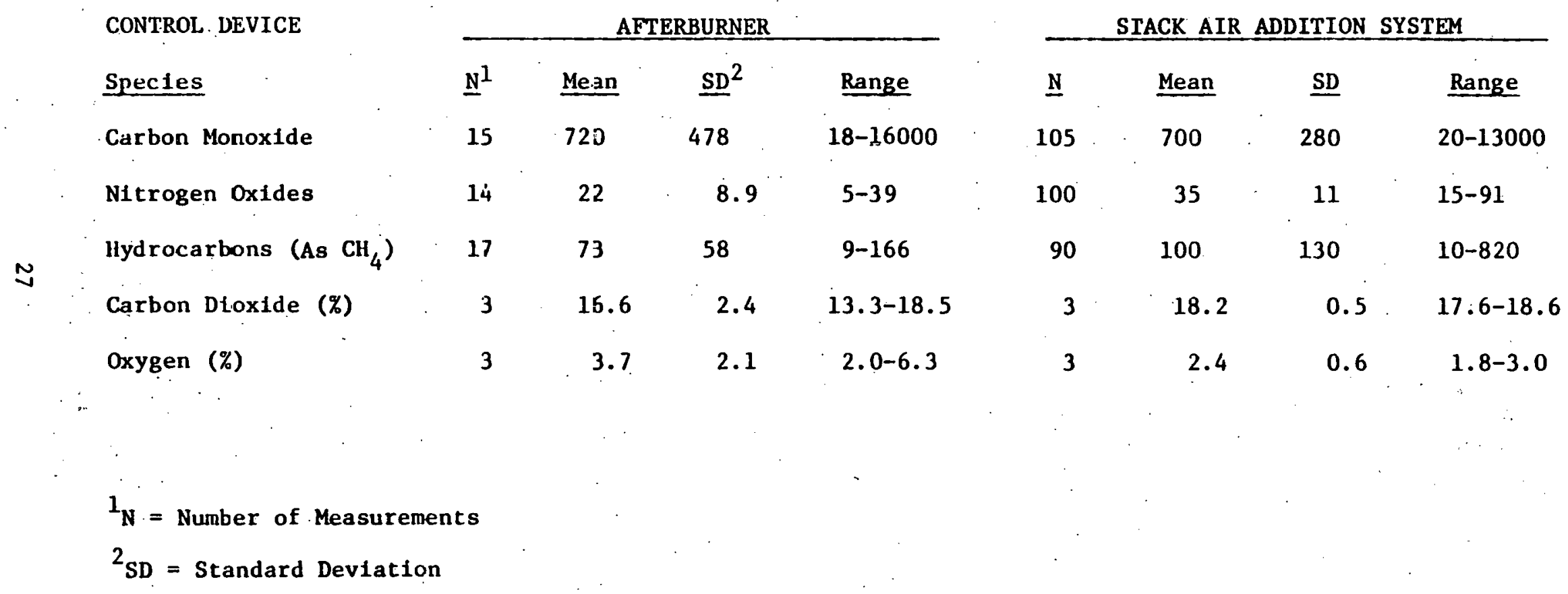


As a quality assurance step, the proper operation of the gas sampling train was checked prior to routine collection of gas concentration data. The major polnt of concern was whether the sampling line/manifold was leak tight. Duplicate ORSAT samples (EPA Method 3 ) were taken at the stack through the pitot tube on the probe and subsequently at the exhaust point of the heated gas sampling manifold. The data which are shown below, Indicate that no appreclable leak was present.

COMPARATIVE ORSAT DATA

(Concentration, $\mathrm{v} / \mathrm{v}$ )

$\begin{array}{lrc}\text { Species } & \text { Stack } & \text { Gas Sample Manifold } \\ \text { Carbon Dioxide }\left(\mathrm{CO}_{2}\right) & 18.5 \% & 16.7 \% \\ \text { Oxygen }\left(\mathrm{O}_{2}\right) & 2.1 \% & 2.1 \% \\ \text { Carbon Monoxide }(\mathrm{CO}) & 0.2 \% & 0.2 \%\end{array}$

The difference in $\mathrm{CO}_{2}$ levels is typical of fluctuations in the stack concentrations over time. Although the lower $\mathrm{CO}_{2}$ concentration in the manifold could have resulted from a small leak of ambient air, the identical concentrations for $\mathrm{O}_{2}$ and $\mathrm{CO}$ Indicate that the system is in fact leakfree. Following this QA check, the ORSAT method was used once daily (duplicate measurement) to measure the concentration of $\mathrm{CO}_{2}$ and $\mathrm{O}_{2}$ in the stack. These data are also reported in Table 2.

\section{B. RESULTS OF COMPREHENSIVE ANALYSIS}

\section{Total Particulate Loading}

The total mass of collected particulates as well as the concentration of particulätes in the source for six (Runs 2-7) MS samples are given in Table 3. The mean concentration of particulates in the stack is slightiy lower when operating the stack air addition system rather than the afterburner. Specifically, the mean concentrations for the stack air addition system and afterburner are $3.7 \mathrm{~g} / \mathrm{m}^{3}$ and $4.8 \mathrm{~g} / \mathrm{m}^{3}$; respectively. However, the difference is not statistically significant. That is, the means are not different at the $95 \%$ confidence level as determined by the Student's t-test. 
TABLE 3

MASS AND CONCENTRATION OF PARTICULATES

Run

Control Device

Volume of gas sampled $\mathrm{m}^{3}$ (STP)
2

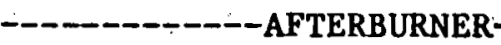

2.14

3.89

3.30

Collected mass of particulates ( $g$ )

$\begin{array}{lrrr}\text { Probe; cyclone } & 5.7699 & 11.8304 & 8.5459 \\ \text { F1lter } & 4.8137 & 7.4849 & 6.2617 \\ \text { Total } & 10.5836 & 19.3153 & 14.8076\end{array}$

Concentration $\left(\mathrm{g} / \mathrm{m}^{3}\right)$

Probe; cyclone

Pilter

Total

$\begin{array}{lll}2.70 & 3.04 & 2.59 \\ 2.25 & 1.92 & 1.90 \\ 4.94 & 4.96 & 4.49\end{array}$

Mean Total Concentration $\left(\mathrm{g} / \mathrm{m}^{3}\right)-4.8$

Standard Deviation - 0.26 
TABLE 3 (continued)

MASS AND CONCENTRATION OF PARTICULATES

Run

Control Derice

Volume of gas sampled $\mathrm{m}^{3}$ (STP)

Collected nass of particulates (g)

Probe; cyclone

Filter

Total

Concentration $\left(3 / \mathrm{m}^{3}\right)$

Probe; cyclone

Fil.ter

Total
5

6

7

----STACK AIR ADDITION-
0.97
3.33
4.33

$\begin{array}{lll}2.37 & 2.29 & 1.44 \\ 0.89 & 2.71 & 1.36 \\ 3.26 & 5.00 & 2.80\end{array}$

Mean Total Ccncentration $\left(\mathrm{g} / \mathrm{m}^{3}\right)-3.7$

standand Deviation - 1.2 
In wuch of the data discussed in following sections, it is apparent that the agreement within stack afr addition (SAA) data is poorer than within afterburner (AFB) data. It is not known whether this greater varlability in SAA data 19 due to operation of the SAA system or operation of the foundry itself. That is, was variation due to differences in charging production rates during the week that the SAA was tested? Varlability in operation of the MS train 18 not a probable cause of the observed data varfance, except in case of malfunction; no unusual situations were noted.

The variation in concentrations calculated for the probe/cyclone and filter sections of the MMS train is great enough that it is difficult to confirm the shift in particle size distribution reported for the SAA control device by Davis and Draper, 1981 (12). However, the data generated in the present study do not contradict this earlier observation.

\section{Leve1 1 Organic Analysis}

Mass concentrations of total extractable organic material collected in the various MS train components (1.e., filter, sorbent, condensate) from both afterburner and stack air addition runs are reported in Table 4 and sumarized in Figure 10 and 11 . In comparison to the total particulate mass coricentration observed (Table 3 ), very little organic matter was extracted from the samples. Only about $0.1 \%$ of the total particulate mass collected in the probe, filter, and cyclone was extractable wh1le about $1 \%$ of the total mass of material collected in. the entre sampling train (i.e., including sorbent and condensate) was extractable in dichloromethane. All dichloromethane-extractable mass has been identified as organic matter.

The organic extractable matter was experimentally divided into a low bollIng point fraction defined as total chromatographable organics (TCO) and a high bolling point fraction defined as gravimetric analysis (GRAV) organics. 
TABLE - 4

TOTAL EXTRACTABLE ORGANICS ( $\mathrm{mg} / \mathrm{m}^{3}$;

(Corrected for blanks)

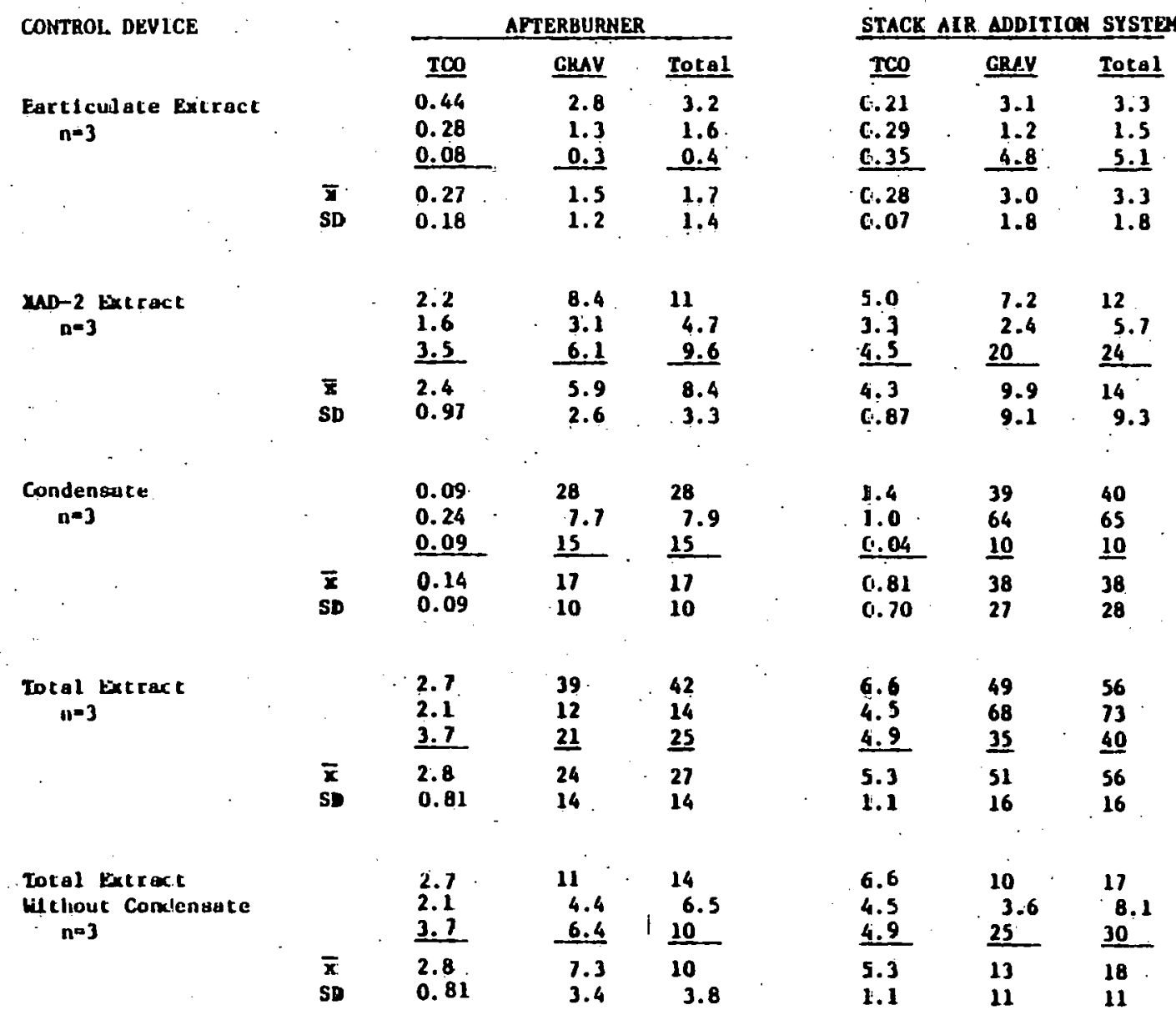




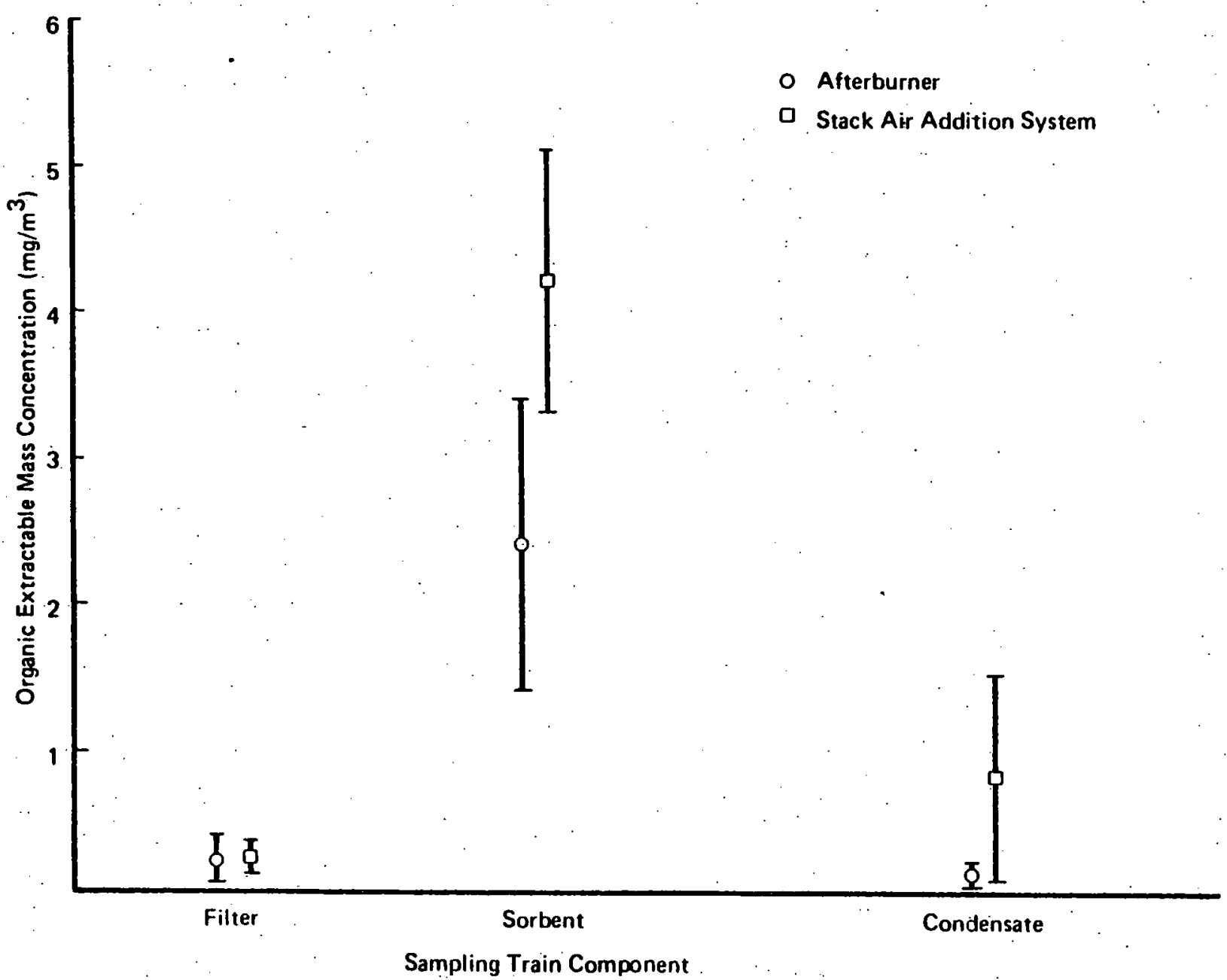

FIGURE 10 DISTRIBUTION OF LOW BOILING ITCOI ORGANICS 


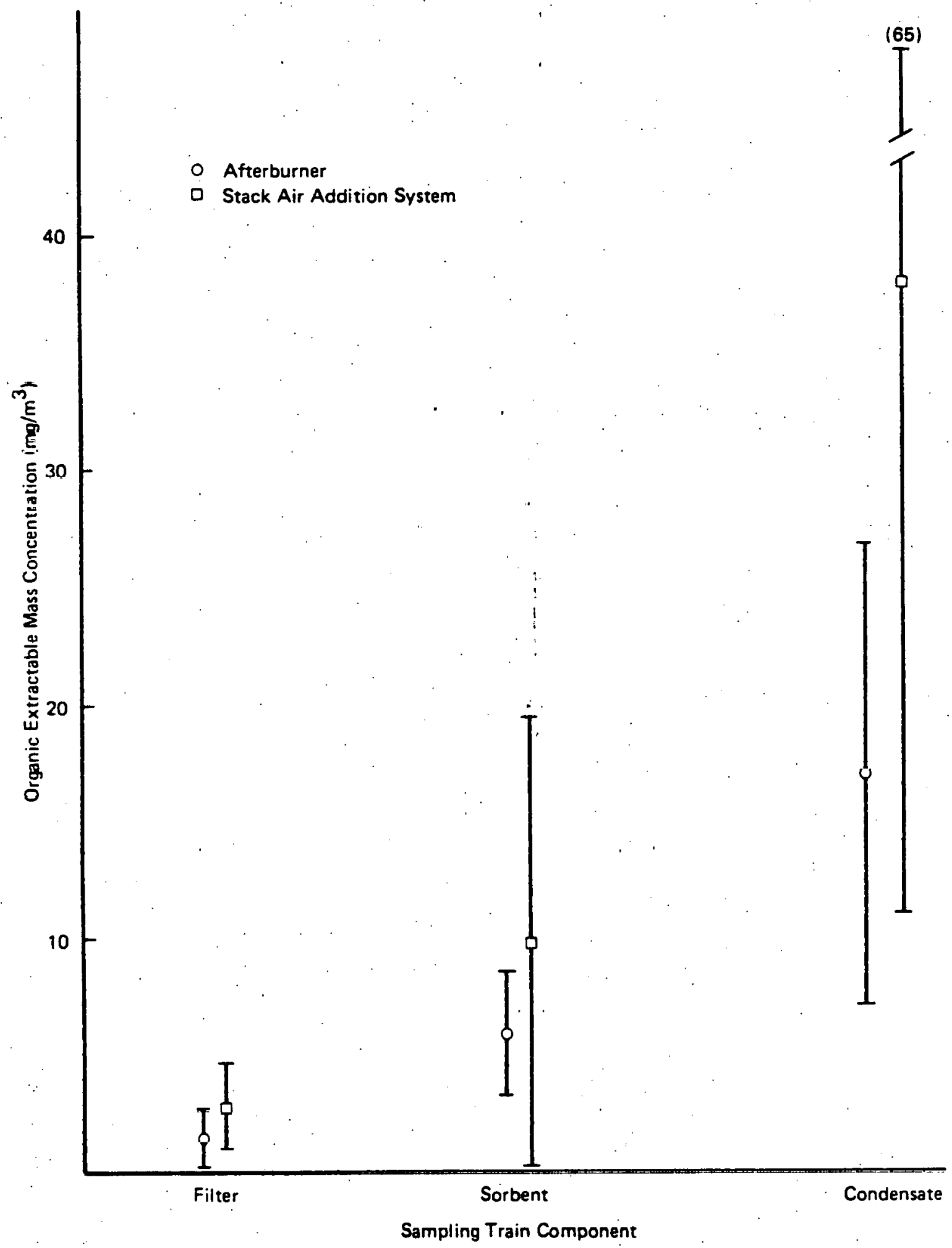

FIGURE 11 DISTRIBUTION OF HIGH BOILING (GRAV) ORGANICS 
The distribution of extractable organic matter in the sampling train components Indicates that about $80-86 \%$ of the organics which fall into the TCO range (boiling point between $100^{\circ}$ and $300^{\circ} \mathrm{C}$ ). are found in the XAD-2 extract. About $71-75 \%$ of the organics which fall into the GRAV range (bolling point greater than $300^{\circ} \mathrm{C}$ ) are found in the condensate. Organic materfal with bolling points greater than $300^{\circ} \mathrm{C}$ accounts for about $89-91 \%$ of the total organic mass. These observations are not completely consistent with findings of other ferroalloy process emission measurements (13). The presence of most of the organic mass in the condensate trap is unexpected. In fact, a careful revlew of the low resolution mass spectroscopy (LRMS) data (Append1x A) indicates that most of the organic material present in the condensate extract consists of dioctylphthalate (DOP) and related esters. This compound is probably due to contamination of the condensate samples in the fleld, although it is not obvious why the contamination appears only in these samples; other train components show minimal DOP contamination. In any case, it seems inappropriate to include the DOP-material in estimates of source-related organic emission. Therefore, the estimated total extractable organic mass concentration is calculated excluding the condensate sample data (Table 4 ) and is summarized in Figure 12.

A comparison of organic concentration data for the afterburner and stack air addition runs indicates that the low bolling $\left(100^{\circ}-300^{\circ} \mathrm{C}\right)$ organic material is present at significantly (1.e., $95 \%$ confidence level by Student's t-test) higher levels in the stack air addition samples. Although the trend is the same for the high boiling $\left(>300^{\circ} \mathrm{C}\right)$ organic material, and thus total organic material, the latter differences are not statistically significant as determined by the Student's t-test.

In order to obtain additional information related to health implications of the observed differences between the organic emission concentrations from the afterburner and stack alr addition system, various EPA/IERL Level 1 chemical analyses were conducted. Individual extracts were analyzed by infrared spectrometry (IR) and low resolution mass spectrometry (LRMS). 


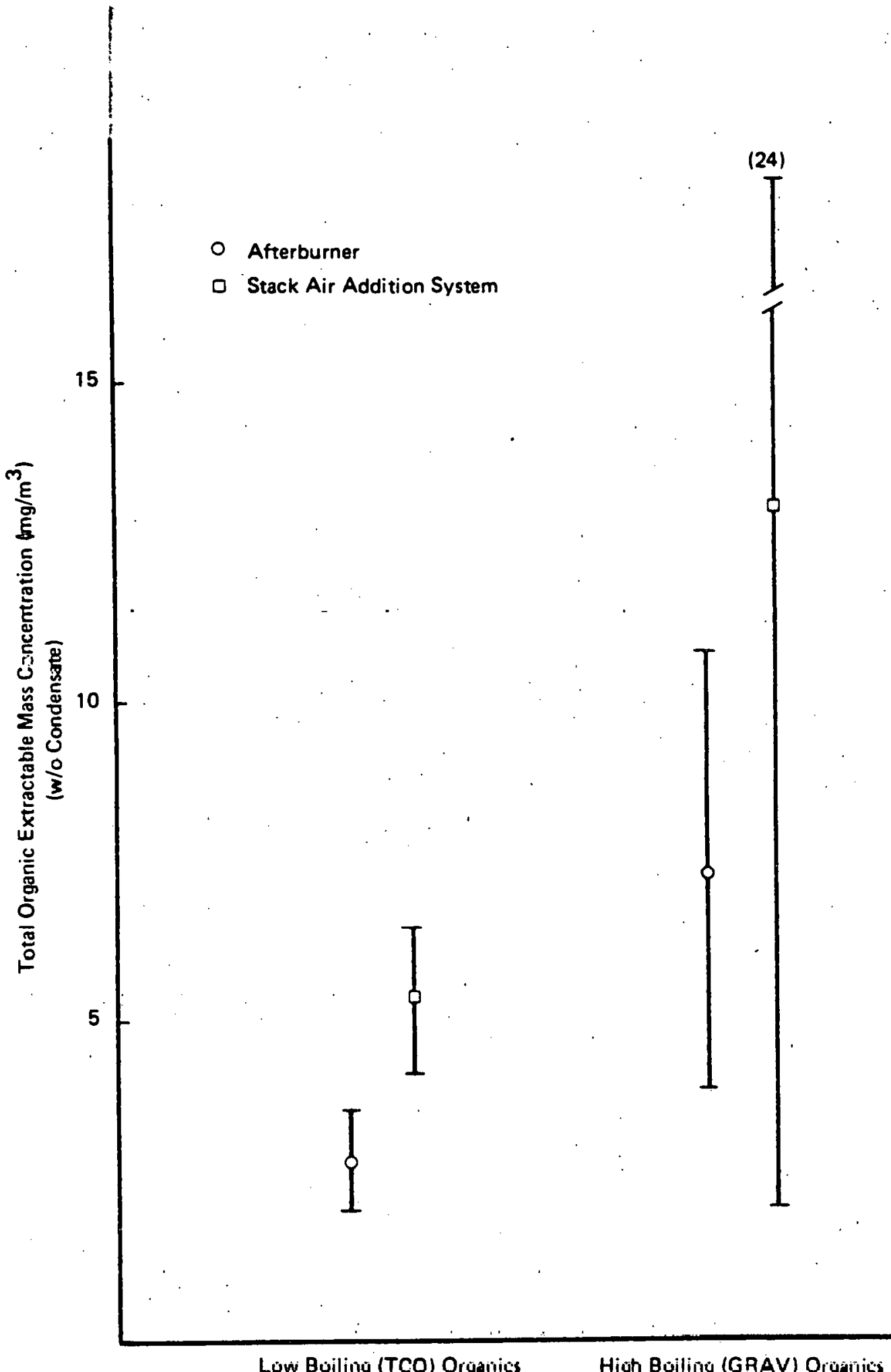

Luw Builing (TCO) Organics

High Boiling (GRAV) Oiganiics

FIGURE 12 COMPARISON OF TOTAL ORGANIC EXTRACTABLE MASS CONCENTRATIONS 
The chemical classification data obtained from these analyses are reported in Appendix A. Due to the low mass of organic extractable material in most samples (excluding condensate samples), only two (sorbent) extracts were of sufficiently high concentration (1.e., greater than $8 \mathrm{mg} / \mathrm{m}^{3}$ ) to warrant a ifquid chromatographic separation on silica gel prior to LRMS analysis. Three composite fractions representative of aliphatic hydrocarbons such as dodecane (Fraction 1) and aromatic hydrocarbons, such as benzene and benzo(a)pyrene (Fractions 2-4), and polar compounds, such as benzoic acid (Fractions 5-7) were collected from each of these two extracts.

On the basis of analysis of unfractionated and fractionated extracts, the organic species in each extract were classified into compound categories and the intensity (relative amount) of each category was estimated using a method developed by Arthur D. Little, Inc. (14). The major components (Intensity $=100$ ) of each fraction of the sampling train are shown in Table 5. Note that a comparison of filter and condensate extracts from the afterburner and stack air addition samples shows identical major components, that 1s, aliphatic hydrocarbons and esters (contamination). The LRMS data for the sorbent extracts from the afterburner and stack air addition samples show marked similarity but indicate that allphatic hydrocarbons may be somewhat more abundant than fused alternate, non-alternate hydrocarbons (i.e., polycyclic aromatic hydrocarbons) in the stack alr addition samples. This may indicate that the larger organic mass concentration observed on the sorbent sample for the stack air addition system may be due to increased amounts of aliphatic hydrocarbons rather than polycyclic aromatic hydrocarbons. In any case, the most abundant polycyclic aromatic hydrocarbons in all samples from both control devices are of less than five rings (molecular weight $<216$ ), most of which are considered to be non-carcinogenic (15). Less abundant amounts of a class of potentially. strongly carcinogenic fused hydrocarbons of five or greater rings (molecular weight $>216$ ) were observed in a few samples from both control systems. It is difficult to state unequivocally that the lower concentration of polycyclic aromatic hydrocarbons in the stack alr addition system will mean less health hazard since it is 1mposstble to preclude possible synergistic 
TABLE 5

MAJOR ORGANIC COMPOUND CATEGJRIES

(Intensity $=100$ or as stat $\equiv d$ )

Control Device

\section{Afterburner}

Filter

Sorbent

(Tota1)

$\underset{\infty}{\omega}$

(Fraction 1)

(Eractions 2-4)

(Fractions 5-7)
Aliphatic hydrocarbons

Fused alternate, non-alteznate hy.dr ocarbons

Carboxylic acids

Allphatic hydrocarbons (10)

Aliphatic hydrocarbons

Alfpatic hydrocarbons

Aromat1c hydrocarbons (10:

Carboxylic ac1ds, aliphat $=c$ alcohols or ketones

Esters
Stack Air Addition System

Aliphatic hydrocarbons

Aliphat1c hydrocarbons

Fused alternate, non-alternate hydrocarbons (10)

Aliphatic hydrocarbons

Aliphatic hydrocarbons Aromatic hydrocarbons (10)

Carboxylic ac1ds, aliphatic alcohols or ketones

Esters 
effects of high molecular weight aliphatic hydrocarbons, which have been implicated as promoters of the indirect carcinogenesis of polycyclic aromatic hydrocarbons in some studies (16).

\section{Inorganic Analysis}

The results of mercury determination (cold vapor atomic absorption method) in sorbent, condensate, $\mathrm{H}_{2} \mathrm{O}_{2}$ impinger, and persulfate impinger fractions are sumarized in Table 6. Mercury is distributed quite equally over these fractions and is present at low loadings corresponding to about $1 \mu \mathrm{g} / \mathrm{m}^{3}$. There is no significant difference between the afterburner (AFB) and stack air addition system (SAA) samples. No arsenic or antimony were detected in these fractions at levels above the detection limit (1.e., $0.4 \mu \mathrm{g} / \mathrm{m}^{3}$ ).

The total inorganics detected by spark source mass spectrometry (Appendix B) are summarized in Tables 7 to 9. Concentrations on a mass emission basis $\left(\mu \mathrm{g} / \mathrm{m}^{3}\right)$ for 10-16 selected elements present at high concentrations are included. Elements with atomic number of less than twelve (Iithium to magnesium) are excluded from the sumary. The results are grouped accordIng to sampling train component. Speciflcally, the metal concentration in the particular fraction, probe/cyclone wash and filter catch, sorbent resin and condensate catch are reported separately. As expected, most of the inorganic material present in the cupola stack is collected on the probe, cyclone and filter. Only a small percent of most elements appear to be distributed in the sorbent or condensate. The obvious exception is sulfur; for this element about $10 \%$ of the mass is found on the sorbent and $10 \%$ in the condensate. This observation is not unexpected due to the potential for the existence of various sulfur compounds in the vapor state.

More importantly, the difference in mass concentration of the elements measured in the samples collected when the afterburner or stack air addition system was in use is not statistically significant. This is consistent with the equivalence of the total particulate mass concentrations for both control devices. 
TABLE 6

MERCURY IN SAMPLE FRACTIONS

(Mean Concentration, $\left.\mathrm{jg} / \mathrm{m}^{3}\right)^{1}$

Matrix

Sorbent

Condensate

$\mathrm{H}_{2} \mathrm{O}_{2}$ Impinger

Persulfate Impinger
Control Device

\begin{tabular}{|c|c|c|c|}
\hline \multicolumn{2}{|c|}{ Afterburner } & \multicolumn{2}{|c|}{ Stack Afr Addit1or } \\
\hline $\bar{x}$ & S.D. & $\bar{x}$ & S.D. \\
\hline 0.77 & 1.0 & $<0.41$ & - \\
\hline 3.2 & 1.4 & 12 & 16 \\
\hline 0.60 & 0.30 & 0.63 & 0.31 \\
\hline 0.41 & 0.14 & 0.67 & 0.37 \\
\hline
\end{tabular}

1 corrected for blank levels 
TABLE 7

SELECTED ELEMENTS IN PARTICULATE FRACTION

(Mean Concentration, $\left.\mu \mathrm{g} / \mathrm{m}^{3}\right)^{1}$

Element
Silicon (SI)
Sulfur (S)
Potassium (K)
Calcium (Ca)
Titanium (TI)
Chromium (Cr)
Manganese (Mn)
Iron (Fe)
Nickel (Ni)
Copper (Cu)
Zinc ( $\mathrm{Cn}$ )
Bromine (Br)
Iin ( $\mathrm{Sn}$ )
Antinony ( $\mathrm{Sb}$ )
Lead (Pb)

Afterburner

\begin{tabular}{rrr}
\hline \multicolumn{1}{c}{$\bar{x}$} & & \multicolumn{1}{c}{ S.D. } \\
MC & \multicolumn{1}{c}{-} \\
150,000 & & 8,900 \\
53,000 & & 12,000 \\
42,000 & 12,000 \\
2,900 & 820 \\
730 & & 380 \\
90,000 & 5,700 \\
120,000 & 8,000 \\
830 & 1,100 \\
1,600 & 830 \\
44,000 & 17,000 \\
7,100 & 2,600 \\
13,000 & 6,900 \\
1,800 & 920 \\
220,000 & 40,000
\end{tabular}

Stack Alr Addtition $\bar{x} \quad$ S.D. MC

$23,000 \quad 22,000$ $99,000 \quad 110,000$ $73,000 \quad 43,000$ $4,900 \quad 5,300$ $420 \quad 174$ $130,000.130,000$ $180,000 . \quad 170,000$ $420 \quad 600$ $600 \quad 240$ $62,000 \quad 46,000$ $22,000 \quad 26,000$ $4,400 \quad 470$ $670 \quad 260$ $140,000 \quad 110,000$

MC $\equiv$ Greater than about 500,000

$I_{\text {corrected for blank levels }}$ 
TABLE 8

SELECTED ELEMENTS IN SORBENT

(Mean Concentration, $\left.\mu g / \mathrm{m}^{3}\right)^{1}$

\begin{tabular}{|c|c|c|c|c|c|}
\hline \multirow[b]{2}{*}{ Element } & \multicolumn{2}{|c|}{ Afterburner } & \multicolumn{2}{|c|}{ Stack Air Addition } & \multirow[b]{2}{*}{ B1ank. } \\
\hline & $\bar{x}$ & S.D. & $\bar{x}$ & S.D. & \\
\hline Sulfur (S) & 15,000 & 12,000 & 4,900 & 3,000 & 5,700 \\
\hline Calcịm (Ca) & 380 & 240 & 78 & 86 & 59 \\
\hline Titanium (Ti) & 51 & 20 & 3.2 & 1.5 & 9.7 \\
\hline Chromium (Cr) & 190 & 160 & 32 & 32 & 40 \\
\hline Iron (Fe) & 1,300 & 970 & 400 & 70 & 160 \\
\hline Nickel (Ni) & 14,000 & 23,000 & 140 & 35 & 49 \\
\hline Copper (Cu) & 230 & 270 & 78 & 86 & 59. \\
\hline Zine $(2 n)$ & 110 & 12 & 320 & 540 & $<180$ \\
\hline Germanium (Ge) & 86 & 100 & $<6.8$ & -- & $<1.2$ \\
\hline Selenium (Se) & 86 & 140 & $<9.4$ & - & 24. \\
\hline
\end{tabular}

1 corrected for blank levels 
TABLE 9

SELECTED ELEMENTS IN CONDENSATE

(Mean Concentration, $\left.\mu g / \mathrm{m}^{3}\right)^{1}$

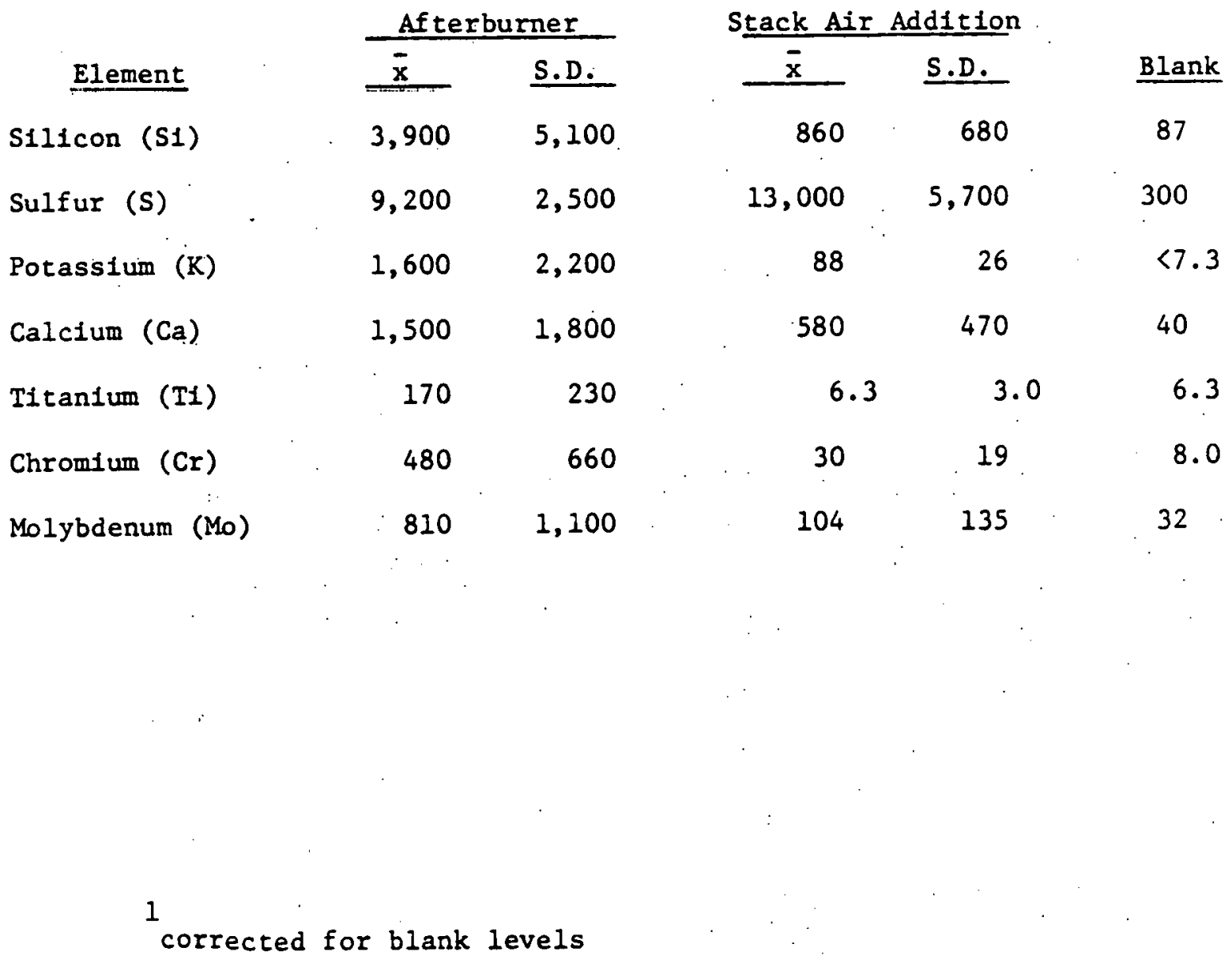


In an attempt to quaptify the levels of sulfur oxides $\left(\mathrm{SO}_{\mathrm{x}}\right)$ in the stack gas, the $\mathrm{SO}_{x}$ collected in the pair of $\mathrm{H}_{2} \mathrm{O}_{2}$ impingers in the MS train were analyzed by ion chromatography as sulfate. The mean concentrations for the samples collected during the operation of the afterburner (AFB) and stack ait addition system (SAA) are as follows:

$\begin{array}{ccr}\text { Control Device } & \frac{\begin{array}{c}\text { Mean Concentration as Sulfate } \\ \left(\mathrm{mg} / \mathrm{m}^{3}\right)\end{array}}{5} \cdot \frac{\text { S.D. }}{821} \\ \text { AFB } & 488 & 150\end{array}$




\section{Microscopic Analys is}

Two particulate samples were examined microscopically to characterize appearance and composition and to measure particle size distribution. A representative aliquot of the particulates (probe, cyclone and filter catches) collected during operation of the afterburner (Run 3) and stack air addition (Run 6) system were examined by optical microscopy at $1,500 x$ and by scanning electron microscopy (SEM) at 5,000-10,000x.

Observations of these samples are as follows:

1. Although a small amount of crystalline materlal is observed to be present in both samples, X-ray diffraction was not able to resolve the identity of this phase.

2. In the polarizing microscope, both particulate samples are observed to consist principally of an amorphous phase; transparent and light tan in color. There are a few black opaque particles, some of which are subject to movement in a magnetic field, i.e., ferromagnetic. There are a few very small crystalline particles attached to or contained within the larger amorphous particles.

3. Observations on the scanning electron microscope and the associated energy dispersive analyzer indicate that the composition of the principal phase includes silicon as major element with manganese, iron, potassium, calcium and zinc also present and decreasing in the order given. Lead appears as an additional element in small amounts.

4. The elemental composition and the observations in the optical microscope indicate that the light tan amorphous phase is a glassy silicate. 
5. Two sets of photomlcrographs were taken of each sample. Views at 80x magnification and under partially polarized light 1llustrate the variety and appearance of both samples (Figures 13 and 14 ).

6. Photographs taken at $20 \mathrm{x}$ were used to obtain the particle size distribution (Table 10). This magnification range was chosen because a number of particles in both samples are relatively large and thus represent a large welght or volume percent. A large number of particles which are smaller than $100 \mu \mathrm{m}$ are present and are not well resolved at chls magnificatiou.

7. Due to the fact that the particle size distribution peaked near the ilmit of resolution of the optical microscope at $20 \mathrm{x}$ to $100 x$, the samples were reexamined with the optical microscope using an oil immersion $1500 x$ objective. This shows the individual large particles to be aggregaces of many smaller particles, some of which are distinctly spherical. Some of these small spheres are colored: red, brown and also black opaque. There are also a few crystalline particles dispersed In the aggregatc. It was also noted that a very large percent (on a number basis) of the particulates were of a size range near the limit of resolution.

8. Therefore, additional observations with the scanning electron microscope (SEM) were made. These confirm that these larger particles are, in fact, aggregates of small spherical beads below one micrometer in diamater (Figure 15). These small particles are indicative of condensation and aggregation prucesses in the cupola. 
TABLE 10

PARTICLE SIZE DISTRIBUTION BY OPTICAL MICROSCOPY

Control Device

Afterburner

Stack Air Addition

Size Range:

$$
\begin{aligned}
& 0-0.2 \\
& 0.2-0.4 \\
& 0.4-0.6 \\
& 0.6-0.8 \\
& 0.8-1.0
\end{aligned}
$$

Number Counted

Mean Particle Size (mm)

Standard Deviation
91

19

1

1

0

112

0.14

0.10
0.09

120

40

2

0

162

0.15 

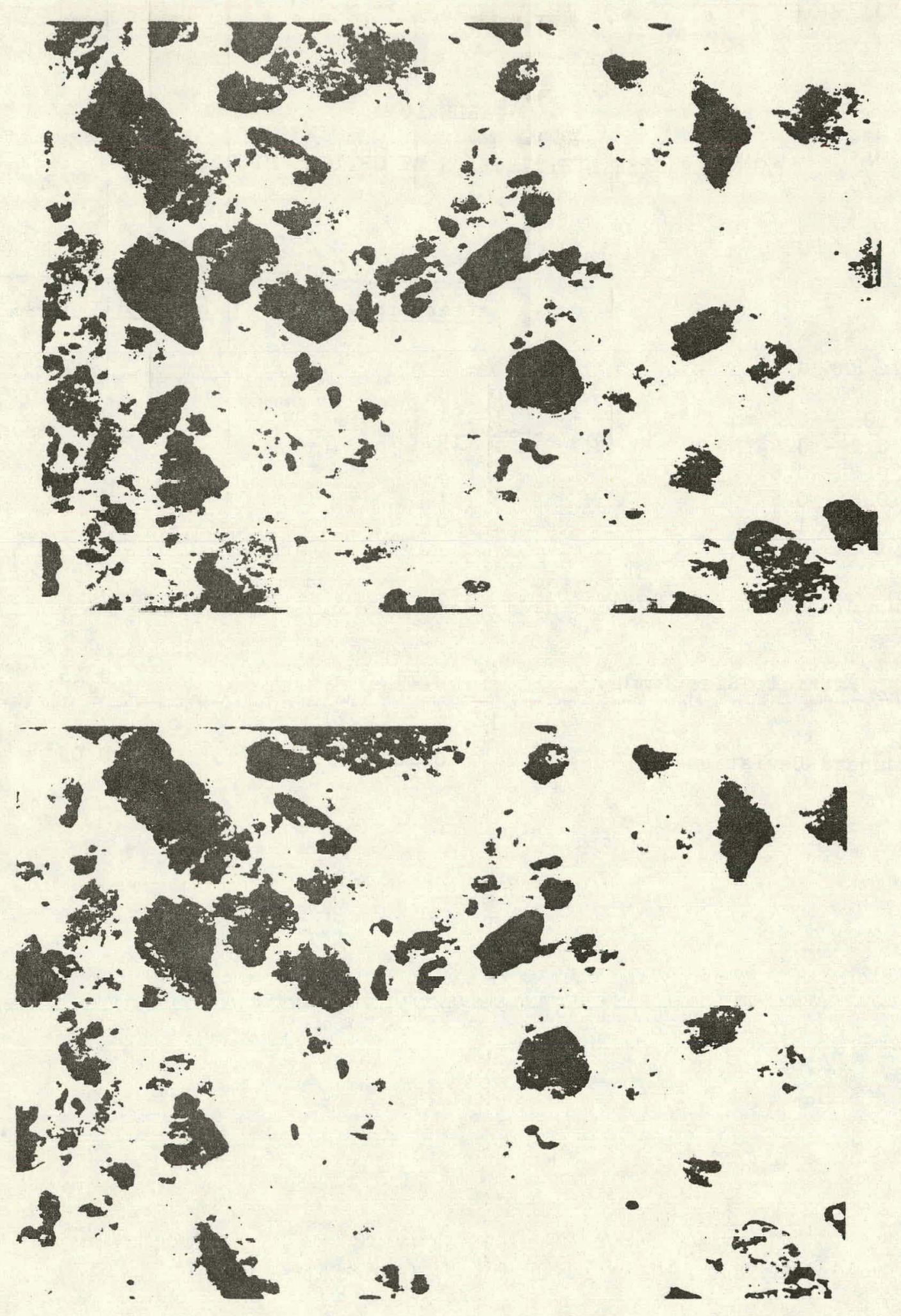

FIGURE 13. PARTICULATE FROM STACK AIR ADDITION SYSTEM Bright Field Illumination, Top Partially Polarized Light, Bottom 

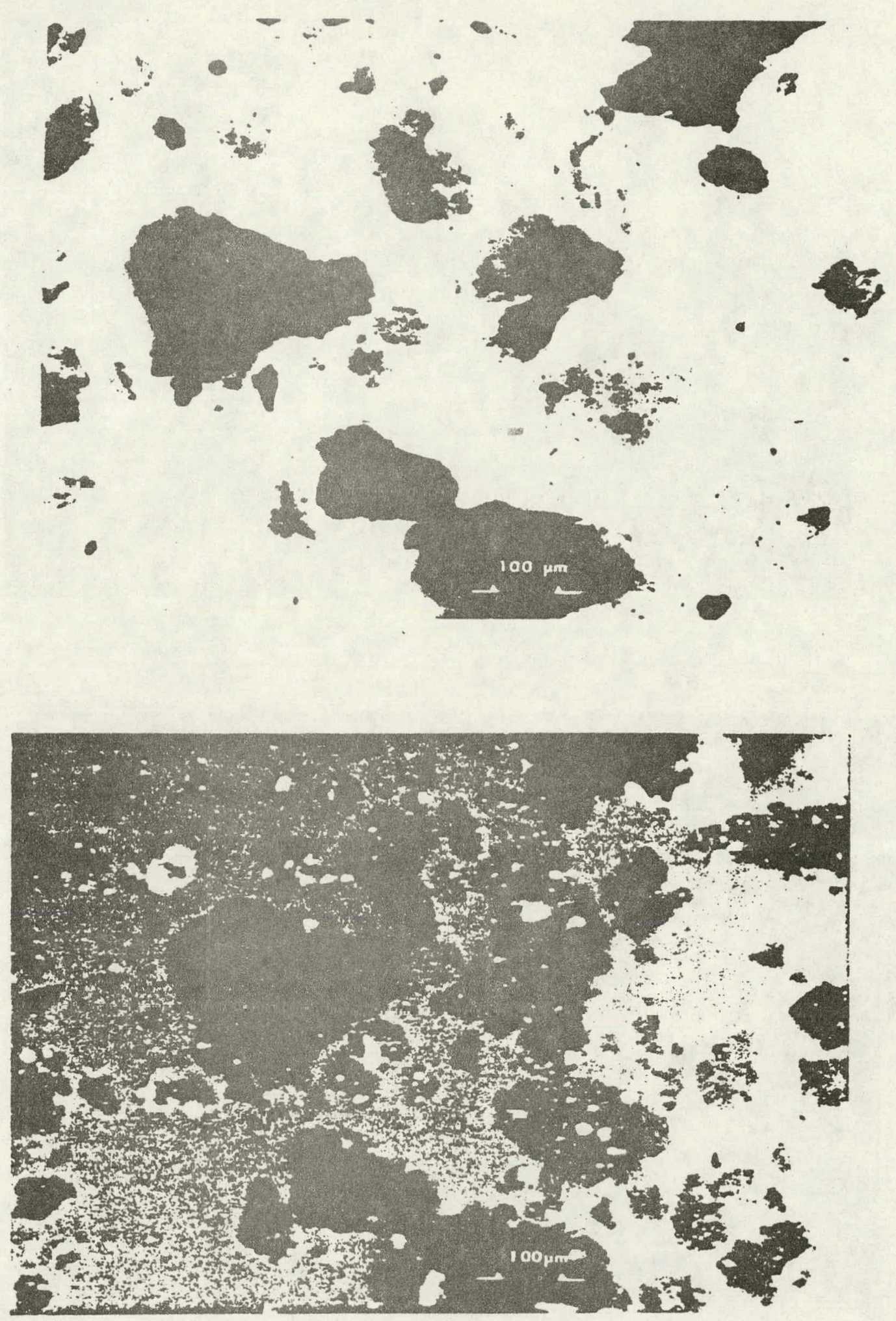

FIGURE 14. PARTICULATES FROM AFTERBURNER Bright Field Illumination, Top Partially Polazarized Light, Bottom 

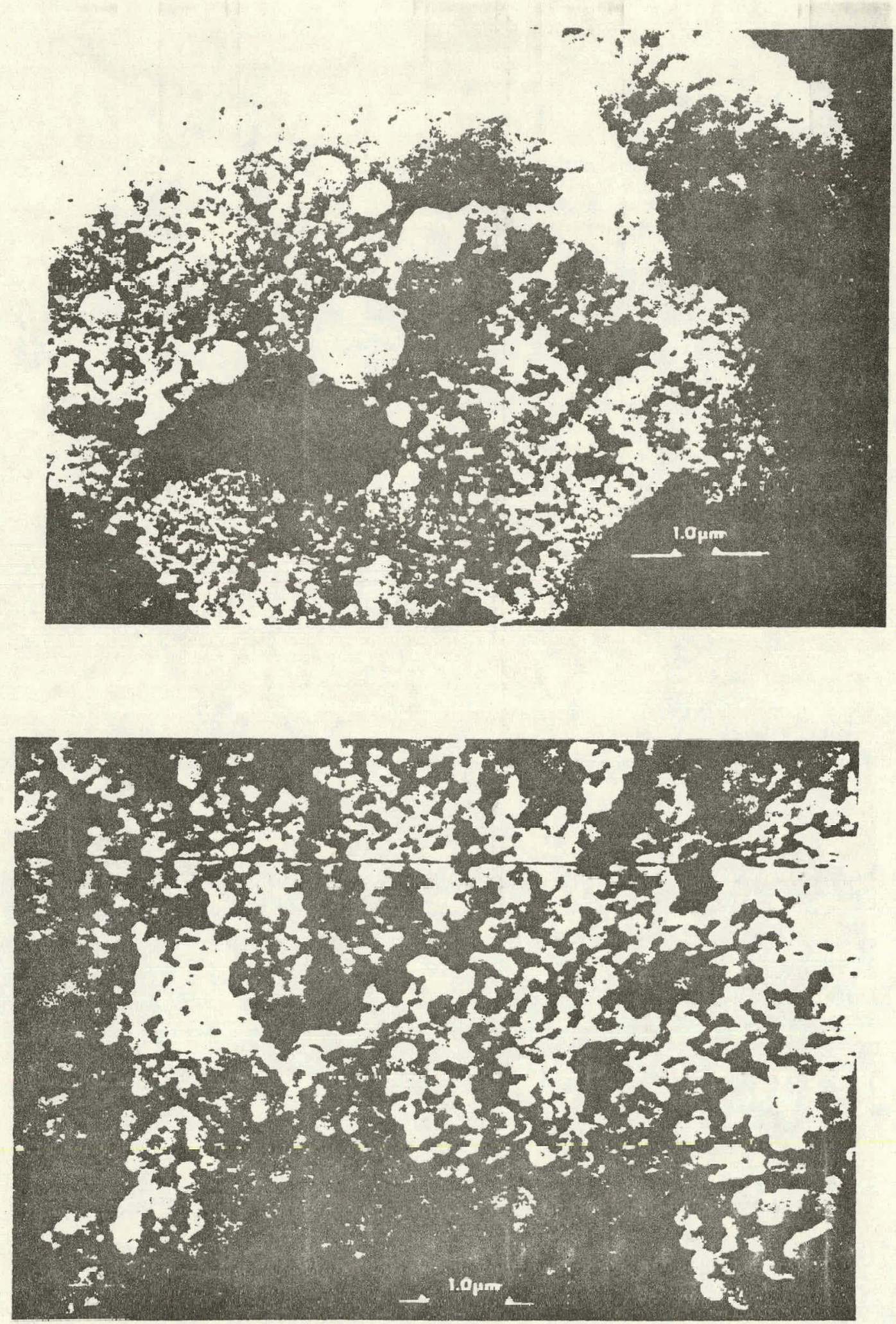

FIGURE 15. SEM PHOTOMICROGRAPH OF AGGREGATE PARTICULATES $(12,000 x)$ 
9. The SEM observation that a large fraction of particles are less than $10 \mu \mathrm{m}$ in diameter and the optical microscopic observation of a mean particle size of about. 150 min tends to confirm the bimodal size distribution reported by Davis and Draper, 1981 (12). 
THIS PAGE

\section{WAS INTENTIONALLY LEFT BLANK}




\section{LITERATURE CITED}

1. Lentzen, D.E., Wagoner, D.E., Estes, E.D., and Gutknecht, W.F., IERL-RTP Procedures Manual: Level I Environmental Assessment (Second Edition) NTIS No. PB293795.

2. 40 CFR, 61, July 1, 1981.

3. 40 CFR, 60, July 1, 1981.

4. Rao, C.N.R., "Chemical Applications of Infrared and Raman Spectroscopy," Firșt Edition, Academic Press, London, England, 1963, 683 PP.

5. Colthop, N.B., Lawrence, H.D., and Wiberley, S.E., "Introduction to Infrared and Raman Spectroscopy," First Edition, Academic Press, London, England, 511 pp.

6. Cross, A.D., "An Introduction to Practical Infrared Spectroscopy," First Edition, Butterworth, Inc., Washington, D.C., 1964, 86 pp.

7. Kendall, D.N., "Applied Infrared Spectroscopy," First Edition, Reinhold Publishing Corporation, New York, N.Y., 1966, 560 pp.

8. Reed, R.I., "Applications of Mass Spectrometry to Organic Chemistry," Academic Press, New York, 1966.

9. Budzikiewicz, H., Djerassi, C., and William, D., "Mass Spectrometry of Organic Compounds," Holden Day, Inc., San Francisco, California, 1976.

10. "Eight Peak Index of Mass Spectra," Mass Spectrometry Data Centre, AWRE, Aldermaston, Reading RG74PR, U.K., 1970, First Edition.

11. API Research Project 44, "Selected Mass Spectral Data," Thermodynamics Research Center, Texas A\&M University, College Station, Texas, 1975.

12. Davis, J.W. and Draper, A.B., "Part1cle Site Distribution and Carbon Monoxide Measurements Conducted In Conjunction with a Level 1 Test at NOCA Foundry," Report for DOE under Contract. No. DE-ASO2-76C540028, December, 1981.

13. Rudolph, J.L., Harris, J.C., Grosser, Z.A., and Levins, P.L., "Ferroalloy Process Omissions Measurement," EPA-600/2-79-045, February 1979. 
14. Stauffer, J.L., "Interpretation of Low Resolution Mass Spectra for Level 1 Analysis of Environmental Mixtures," Final Report to EPA under Contract No. 68-02-3111, September 1980.

15. Public Health Service Survey of Compounds Which Have Been Tested for Carcinogenic Activity, Publication No. 149.

16. Slaga, T.J., Sivak, A., and Boutwell, R.K., Editors, "Carcinogenesis: A Comprehenstve Survey, " Volume 2, Mechanisms of Tumor Production and Cocarcinogenesis," Raven Press, New York, 1978. 
APPENDIX A

LEVEL 1 - ORGANIC ANALYSIS DATA

- INFRARED (IR) REPORTS

- LOW RESOLUTION MASS SPECTROMETRY (LRMS) REPORTS 


\section{THIS PAGE WAS INTENTIONALLY LEFT BLANK}




\section{IEVEL 1 - ORGANIC ANALYSIS DATA}

TABLE OF CONTENTS

Run 2 - IR Report $\quad 59$ LRMS Report 61

Run 3 - IR Report $\quad 64$ LRMS Report $\quad 66$

Run 4 - IR Report

LRMS Report $\quad 72$

Stack Air Addition System Runs $\quad 78$

Run 5 - IR Report 78 LRMS Report $\quad . \quad 80$

Run 6 - IR Report $\quad \ldots \quad 83$

LRMS Report 85

Run 7 - IR Report $\quad 88$

T.RMS Report 91

Matrix Blanks $\quad 97$

$\begin{array}{ll}\text { IR Report } & 97\end{array}$

LRMS Report 101

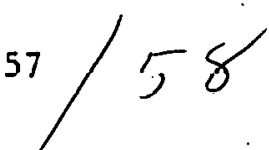


THIS PAGE

\section{WAS INTENTIONALLY}

LEFT BLANK 
IR REPORT

SAMPLE: RUN 2 - AFE - FILTER

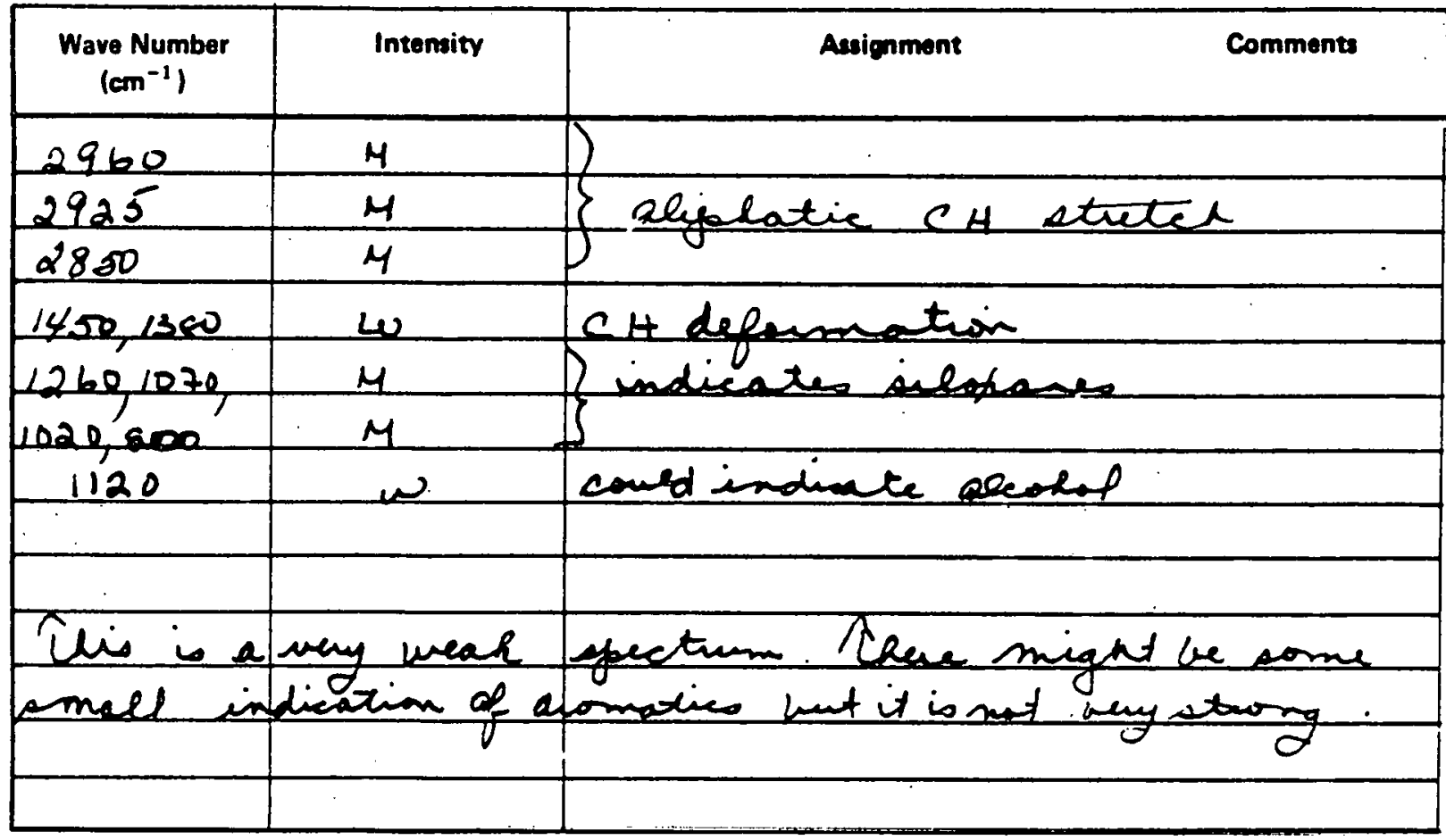

IR REPORT

SAMPLE: RUN 2 - AFB - SORBENT

\begin{tabular}{|c|c|c|}
\hline $\begin{array}{l}\text { Wave Number } \\
\left(\mathrm{cm}^{-1}\right)\end{array}$ & Intensity & Acsignment \\
\hline 3050,3025 & $M$ & aromatic $\mathrm{CH}$ \\
\hline $2960^{\circ}$ & 3 & 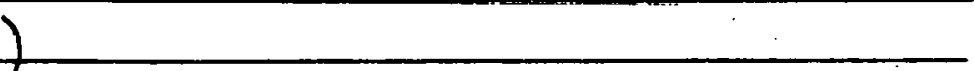 \\
\hline 2920 & s & Geybatia CH etrued \\
\hline 2850 & $M$ & J \\
\hline 1705 & $M$ & $c=0$ of anomatie aldulyde \\
\hline 1600,1500 & $\omega$ & eromatic sing mode \\
\hline 1450,1380 & $M$ & eliphetic $C H$ defomation \\
\hline 1260 & $s$ & 0 \\
\hline 1090 & $S$ & \\
\hline 1040 & $\underline{s}$ & $y$ \\
\hline 800 & $s$ & \\
\hline $900 \cdot 300$ & $M$ & confales aromatic sulustitutiox \\
\hline & & \\
\hline
\end{tabular}


IA REPORT

SAMPLE:_RLN 2-AFB - CONDENSATE

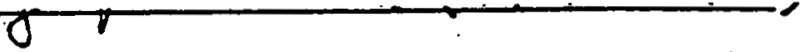

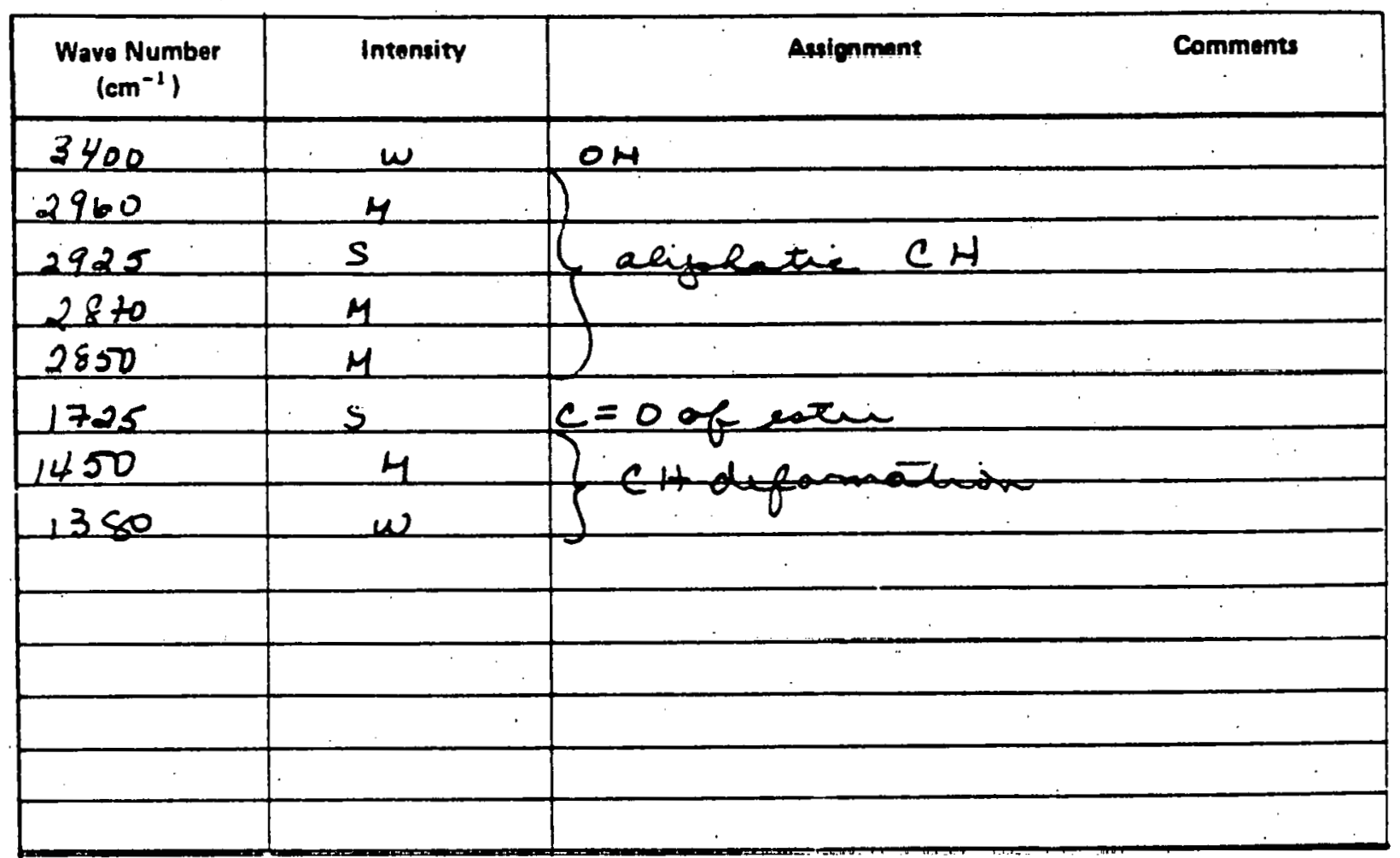


LRMS REPORT

SAMPLE:_ RIJN 2 - AFB - FILTER

Major Categories

\begin{tabular}{|c|c|c|}
\hline Intensity & Category & MW Range \\
\hline $1 \varnothing \varnothing$ & ALIPHATIC HYDRDCARBONS & $T_{0}>35 \phi$ \\
\hline $1 \phi \phi$ & SILICNES & $F_{0}>5 \phi \phi$ \\
\hline 10 & FUSED ALTERNATE, NON ALTERNATE HYDROCARGSUIS & $<216$ \\
\hline $1 \varnothing$ & ESTERS & $=$ \\
\hline 10 & UNCLASSIFIED & $100-350$ \\
\hline
\end{tabular}

Sub-Categorles, Speciflc Cumpuuids

\begin{tabular}{|c|c|c|c|}
\hline Intensity & Category & $m / \theta$ & Composition \\
\hline $1 \phi \phi$ & SILANE-NAATTHLLNEDIOXY-BIS/TRIMETHAL- & 304 & $\mathrm{C}_{16} \mathrm{H}_{24} \mathrm{O}_{2} \mathrm{~S}_{2}$ \\
\hline $1 \varnothing$ & \multicolumn{3}{|c|}{ PAtrhalates nOT SPECIFICALY IDENTIFAabLe } \\
\hline 10 & 4 RING PAH (FUDRGattiane PYRENE) & 202 & $\mathrm{C}_{16} \mathrm{H}_{16}$ \\
\hline & & & \\
\hline & & & \\
\hline & & & \\
\hline & & & \\
\hline & & & \\
\hline & & & \\
\hline & & & \\
\hline & & & \\
\hline & . & & \\
\hline & & & \\
\hline & & & \\
\hline & & & \\
\hline & & & \\
\hline & & & \\
\hline & & & \\
\hline
\end{tabular}

Other

$1 \phi$ SilCONES TO $\mathrm{m} / \mathrm{z} \sim 5 \phi \phi$

$1 \phi$ AlKYL PHendL LiKe material as Part of unclassified 


\section{LRMS REPORT}

SAMPLE: RUN 2 - AFB - SORBENT

\section{Major Categories}

\begin{tabular}{|c|c|c|}
\hline Intensity & Category & MW Range \\
\hline $1 \phi \phi$ & FUSED ALTERNATE, NONALTEANATE HYDRUCARB BOUS & $<216$ \\
\hline $1 \phi$ & ESTERS & - \\
\hline $1 \phi$ & SILICONES & T0 \\
\hline $1 \phi$ & AROMATIC HYDROCARBONS & $23 \phi$ \\
\hline & & \\
\hline & & \\
\hline
\end{tabular}

Sub-Categories, Specific Compounds

\begin{tabular}{|c|c|c|c|}
\hline imtersity & Category & $\overline{m / e}$ & Compusitiun \\
\hline $10 \phi$ & 3 RING PAH ANTHECACENE Pitentanthede & 178 & $C_{14} A_{10}$ \\
\hline 18 & PHENYL XAPATHALENE! & 204 & $\mathrm{C}_{16} \mathrm{H} / 2$ \\
\hline 10 & 4 RING PAH (FLuORanthene/PYRENE) & $2 \phi_{2}$ & $\mathrm{C}_{16} \mathrm{H}_{10}$ \\
\hline 10 & METHYL 3 RING PAXI & 192 & $\mathrm{C}_{15} \mathrm{H}_{12}$ \\
\hline 10 & METHEL PHENYL NAPHTHALLENE & $2 / 8$ & $\mathrm{C}_{7} \mathrm{~A}_{14}$ \\
\hline 10 & TEREPHENYS & 230 & $\mathrm{C}_{18} \mathrm{H}_{14}$ \\
\hline 10 & PHTHALATES, NoT SPECIFICALLY & & \\
\hline & IDENTIFIAGLE & & \\
\hline & & & \\
\hline & & & \\
\hline & & & \\
\hline & & & \\
\hline & & & \\
\hline & & & \\
\hline & & & \\
\hline & & & \\
\hline & & & \\
\hline & & & \\
\hline
\end{tabular}

Other 


\section{LRMS REPORT}

SAMPLE: RUN 2 - AFB - CONDENSATE

\section{Major Categories}

\begin{tabular}{|c|c|c|}
\hline Intensity & Category & MW Range \\
\hline $1 \phi \phi$ & ESTEKS & 390 \\
\hline $1 \varnothing$ & FUSED ALTERNATE, NOU ALTERNATE HYDRocarboUS & $\angle 216$ \\
\hline 1 & Aromatic AYDRDCARBONS & 230 \\
\hline 1 & FUSED aLTERNATE, Nol alternate Hydrocaresons & $>216$ \\
\hline & & \\
\hline
\end{tabular}

Sub-Categuries, Specific Cornipounds

\begin{tabular}{|c|c|c|c|}
\hline Intensity & Category & $\mathrm{m} / \mathrm{e}$ & Composition \\
\hline $1 \phi \varnothing$ & PHTHALATE, DOP TYPE & 390 & $\mathrm{C}_{24} \mathrm{H}_{38} \mathrm{O}_{4}$ \\
\hline $1 \phi$ & 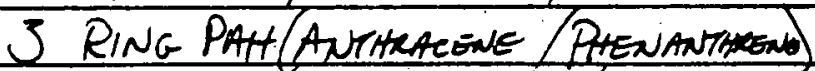 & 178 & CAHAD \\
\hline 10 & 4 RING PAH (Fuorantáne/PYRENe) & $2 \varnothing 2$ & $C_{16} H_{1 \varnothing}$ \\
\hline $7 \varnothing$ & PHenYl Naphtithene & 204 & $C_{16} / t_{12}$ \\
\hline 1 & METIHL 3 RING PAHA & 192 & $C_{15} H_{12}$ \\
\hline 1 & 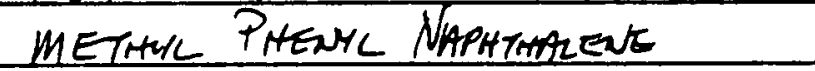 & 218 & $\mathrm{C}_{17} \mathrm{H}_{14}$ \\
\hline 1 & TEREPHENYL & 230 & $\mathrm{C}_{18} \mathrm{H}_{14}$ \\
\hline & & & \\
\hline & & & \\
\hline & & & \\
\hline & & & \\
\hline & & & \\
\hline & & & \\
\hline & & & \\
\hline & & & \\
\hline & & & \\
\hline & & & \\
\hline & & & \\
\hline
\end{tabular}

\section{Other}


IR REPORT

SAMPLE: RUN 3 - AFB - FILTER

\begin{tabular}{|c|c|c|}
\hline $\begin{array}{c}\text { Wave Number } \\
\left(\mathrm{cm}^{-1}\right)\end{array}$ & Intensity & Alaignment \\
\hline 2960 & $M$ & 1 \\
\hline 2920 & $M$ & Gailatic CH statel \\
\hline 2850 & $M$ & S \\
\hline 3050 & $\sqrt{1} 2$ & arometie CH \\
\hline 1450,1380 & $M$ & cH duformation \\
\hline 1260 & $\mathbf{s}$ & 1 \\
\hline 1090 & 9 & Alopene \\
\hline 1020 & $\underline{s}$ & 0 \\
\hline 800 & $s$ & $L$ \\
\hline 700,760 & $\omega$ & Qumatic subctintion \\
\hline & & cossed be anons subatituted \\
\hline & & \\
\hline & & \\
\hline
\end{tabular}

IR REPORT

SAMPLE: RUN 3 - AFB - SORBENT

U

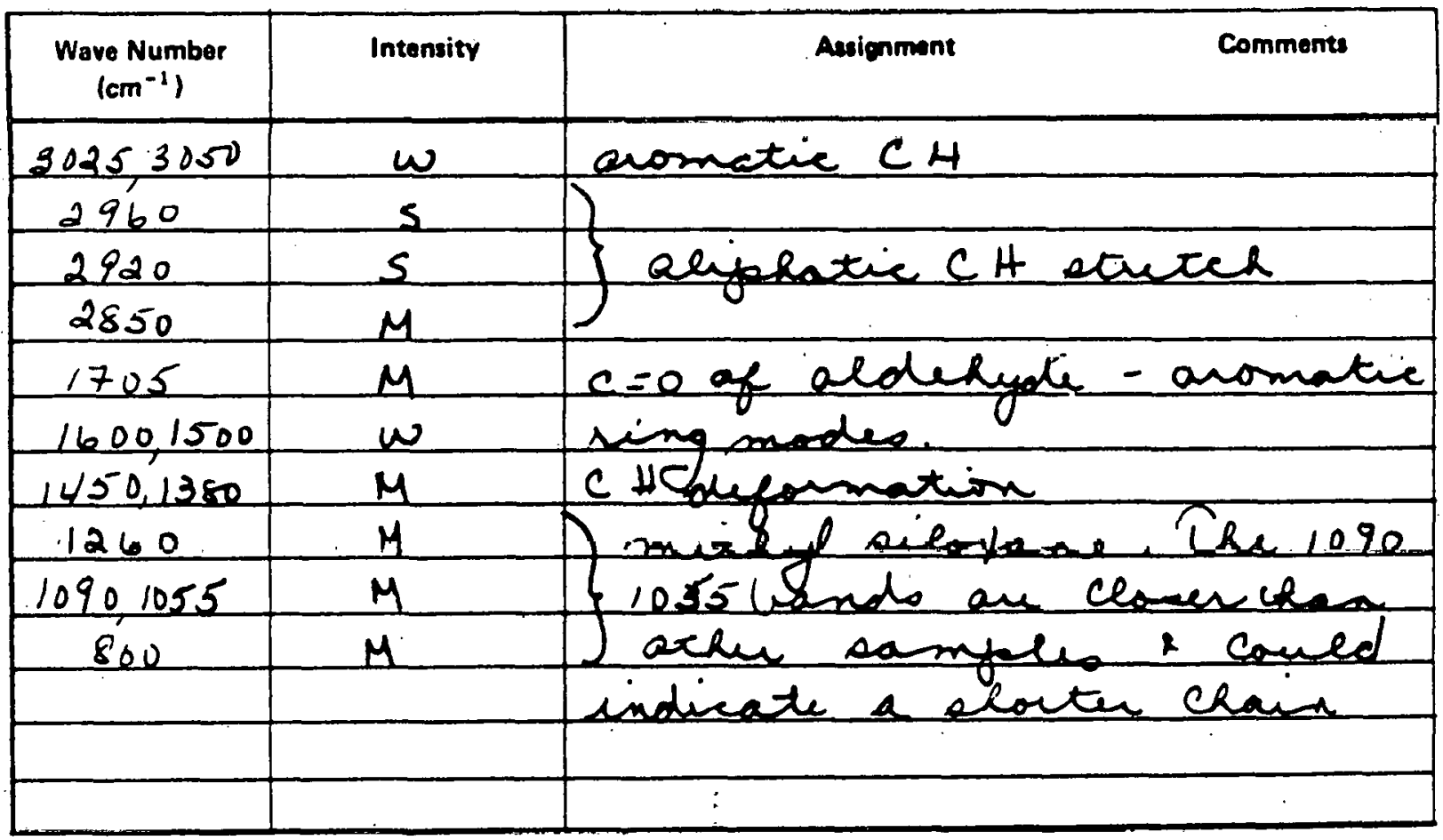


IR REPORT

SAMPLE: RUN 3 - AFB - CONDENSATE

$$
\text { O } O
$$

\begin{tabular}{|c|c|c|}
\hline $\begin{array}{l}\text { Wave Number } \\
\left(\mathrm{cm}^{-1}\right)\end{array}$ & Intomsity & Aasionment \\
\hline 3450 & $\omega$ & Aloonded $\mathrm{OH}$ \\
\hline 3050 & vw & aromatic CH \\
\hline 1730 & ney & $c=0$ mifed \\
\hline 1450 & $\omega$ & \\
\hline 13 sog & $\omega$ & $\underline{S}$ \\
\hline مر & $\omega$ & C-o of alcolal \\
\hline & & \\
\hline Con & ed & ael \\
\hline & & \\
\hline & & \\
\hline & & \\
\hline
\end{tabular}


LRMS REPORT

SAMPLE: _ RUN 3 - AFB - FILTER

Major Categories

\begin{tabular}{|c|c|c|}
\hline Intensity & Category & MW Range \\
\hline $1 \varnothing \varnothing$ & ALIPHATIC HYDROCARBONS & $70>45 \varnothing$ \\
\hline $1 \varnothing$ & S/LICONES & $=$ \\
\hline $1 \varnothing$ & ESTERS & $=$ \\
\hline 10 & FUSED ALTERNATE NON ALTERNATE HYDRUCORSANS & $<216$ \\
\hline & & \\
\hline
\end{tabular}

Sub-Caregories, Specific Compounds

\begin{tabular}{|c|c|c|c|}
\hline Intensity & Category & $m / \mathrm{s}$ & Composition \\
\hline$\therefore$ & PHTIHALATE AND TEREPHTTHALATE, NOT & SPECI & ALLY IDEUTIFIALE \\
\hline 10 & 3 RING PAH (ANTHRACENE/PAENATITHRENE) & 178 & C14tio \\
\hline 10 & Pheayl Naphtihalene & 204 & $\mathrm{C}_{16} \mathrm{H}_{12}$ \\
\hline 10 & I RUNG PAH (FLUORANTHENE/PYRENE) & 202 & $\mathrm{C}_{16} \mathrm{H}_{10}$ \\
\hline 10 & METHL 3 RING PAHI & 192 & $C_{15} A_{12}$ \\
\hline 1 & METIML PHENYL NAPHTHALENE & 218 & $\mathrm{C}_{7} \mathrm{HA}_{14}$ \\
\hline 1 & TEREPAENYL & $23 \phi$ & $\mathrm{C}_{18} \mathrm{H}_{14}$ \\
\hline & & & \\
\hline & & & \\
\hline & & & \\
\hline . & & & \\
\hline & & & \\
\hline & & & \\
\hline & $\therefore$ & & \\
\hline & & & \\
\hline & & & \\
\hline & & & \\
\hline & & & \\
\hline
\end{tabular}

Orhes

$1 \phi$ SILICONES TO $>5 \phi \phi$




\section{LRMS REPORT}

SAMPLE: RUN 3 - AFB - SORBENT

Major Categories

\begin{tabular}{|c|c|c|}
\hline Intensity & Category & MW Range \\
\hline 100 & FUSED ALTERNATE, NDN ALTERNATE HYDRUCARBSUNS & $<216$ \\
\hline $1 \phi \varnothing$ & CARBQXYLIC ACIDS & $122-20 \varnothing$ \\
\hline $1 \varnothing$ & S/LICOJES & $10 \phi-4 \phi \phi$ \\
\hline $1 \varnothing$ & Fused Alternate, Now Alternate Hydrucarbans & $>216$ \\
\hline 10 & UNCLASSIFIEX & $18 \phi-30 \phi$ \\
\hline
\end{tabular}

3ut-Categüries, 3pectific Comisipouinds

\begin{tabular}{|c|c|c|c|}
\hline Intensity & Category & $\mathrm{m} / \mathrm{e}$ & Composition \\
\hline $1 \phi \phi$ & 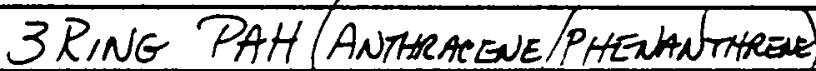 & 178 & $\mathrm{C}_{14 \mathrm{H}, \sigma}$ \\
\hline $1 \phi \varnothing$ & BENZOIC ACD & 122 & $\mathrm{C}_{7} \mathrm{H}_{6} \mathrm{O}_{2}$ \\
\hline 10 & PHENYL NAPHTHALENE & $2 \phi 4$ & $C_{16} H_{12}$ \\
\hline 10 & DiHADRO 3 RING PAH & $18 \phi$ & $\mathrm{C}_{14} \mathrm{H}_{12}$ \\
\hline 10 & 4 Ring PAH (FLuoreanthene/PIRENE) & $2 \phi_{2}$ & $C_{16} H 1 \phi$ \\
\hline 10 & METHYL 3 RING PAH & 192 & $\mathrm{C}_{15} \mathrm{H}_{12}$ \\
\hline $1 \phi$ & DODECANGC ACD & $2 \phi \phi$ & $\mathrm{C}_{12} \mathrm{H}_{24} \mathrm{O}_{2}$ \\
\hline $1 \varnothing$ & Methyl Phenyl Naphthilleve & $2 / 8$ & $\mathrm{C}_{17} \mathrm{H}_{\text {iL }}$ \\
\hline & & & \\
\hline & & & \\
\hline & & & \\
\hline & & & \\
\hline & & & \\
\hline & & & \\
\hline & & & \\
\hline & & & \\
\hline & & & \\
\hline & & & \\
\hline
\end{tabular}

Other

10 MINDR UNDENTIFIE PEAKS, $\mathrm{m} / \mathrm{z} 18 \phi$ TO $3 \phi \varnothing$


LRMS REPORT

SAMPLE: RUN 3 - AFB - CONDENSATE

\section{Major Categories}

\begin{tabular}{|c|c|c|}
\hline Intensity & Category & MW Range \\
\hline $1 \phi \phi$ & ESTERS & $39 \varnothing$ \\
\hline $1 \varnothing$ & FUSED ALTERNATE, NOU ALTERUATE HYDRdCARBSNS. & $<216$ \\
\hline 5 & HETERdCYCLIC NITROGES COMPOUNDS & 135 \\
\hline 5 & HETEROCYCLIC SULFUR COMPOUNDS & 135 \\
\hline 1 & $S / L I C$ ONES & \\
\hline
\end{tabular}

Sub-Categories, Specific Compounds

\begin{tabular}{|c|c|c|c|}
\hline Intensity & Catogory & $\mathrm{m} / \mathrm{o}$ & Composition \\
\hline 100 & PHTHALATE, DOP TYPE & $39 \varnothing$ & $\mathrm{C}_{24} \mathrm{H}_{38} \mathrm{O}_{4}$ \\
\hline 10 & BEUZJTHIAZOZE & 135 & $\mathrm{C}_{7} \mathrm{H}_{5} \mathrm{NS}$ \\
\hline 10 & 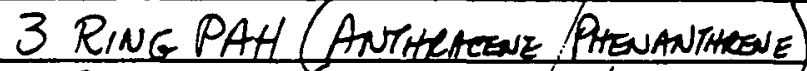 & 178 & $C_{14} A_{10}$ \\
\hline 18 & 4 Ring PAH (Fzunanthene/ Pyrene) & $2 \phi 2$ & $C_{16} A_{10}$ \\
\hline 10 & PhenYl NAPHTHTLENE & $2 \varnothing 4$ & $C_{16} H_{12}$ \\
\hline 1 & METHAL 3 RING PAH & 192 & $C_{15} H_{12}$ \\
\hline 1 & METAYYL PHENYL NaPHAtalene & 218 & $C_{17414}$ \\
\hline & & & \\
\hline & & & \\
\hline & & & \\
\hline & & & \\
\hline & & & \\
\hline & & & \\
\hline & & & \\
\hline & & & \\
\hline & & & \\
\hline & & & \\
\hline & & & \\
\hline
\end{tabular}

Other

\begin{tabular}{|c|}
\hline 1 SILICONES, $7 \mathrm{~m} / \mathrm{z} 475 \phi$ \\
\hline
\end{tabular}


IR REPORT

.SAMPLE: RUN 4 - AFB - FILTER

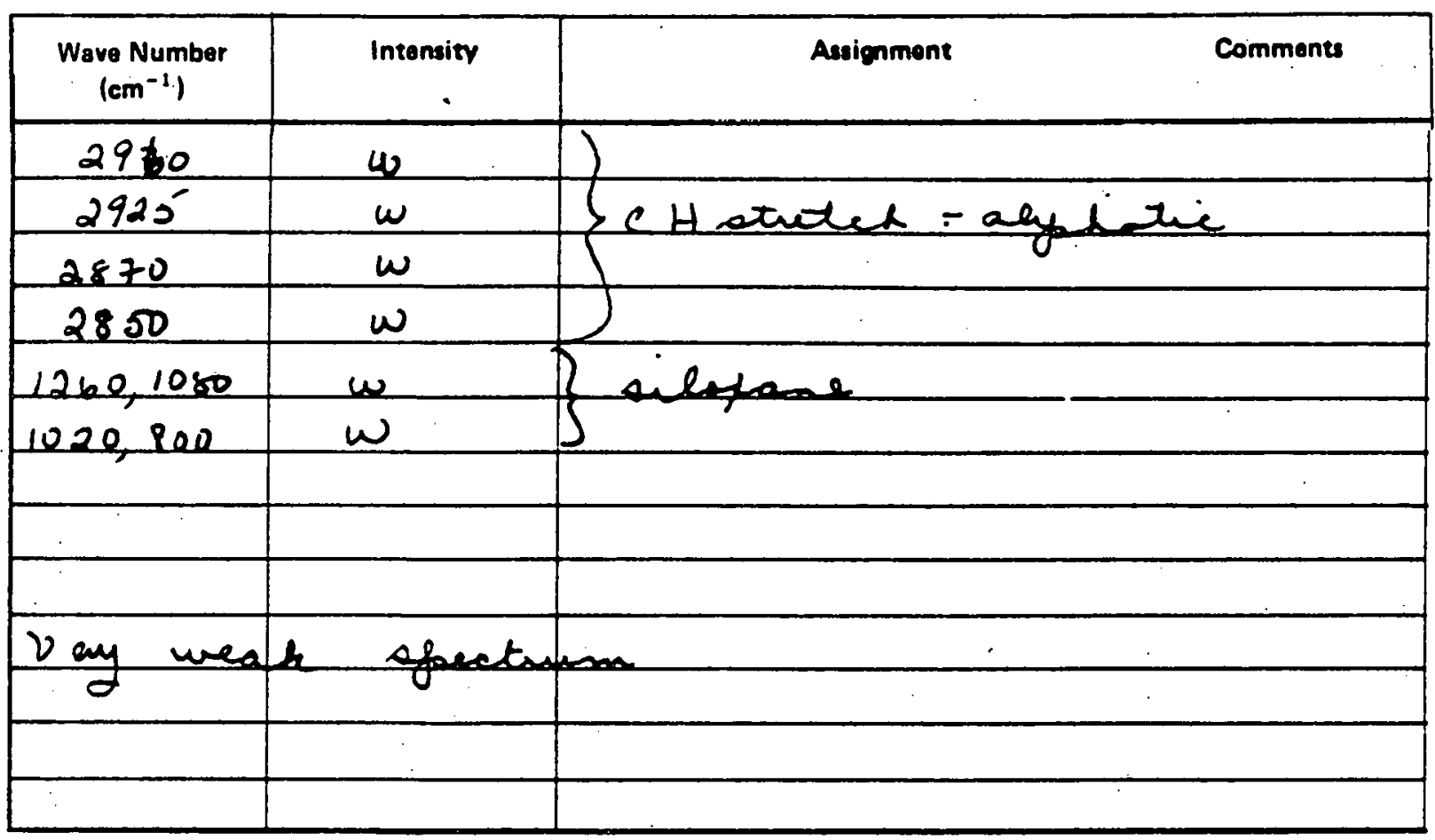

IR REPORT

SAMPLE:

\begin{tabular}{|c|c|c|}
\hline $\begin{array}{l}\text { Wave Number } \\
\left(\mathrm{cm}^{-1}\right)\end{array}$ & Intensity & Assignment \\
\hline 3300 & linoond & $N A$. \\
\hline 2960 & $s$ & \\
\hline 2920 & $S$ & Galiphatic CH stated \\
\hline 2852 & $M$ & \\
\hline 3050 & $\omega$ & Qumatie cH Atentes \\
\hline 1700 & $y$ & $c=0$-amde in conguition winh \\
\hline 1600 & $\omega$ & \\
\hline-1530 & $\omega$ & amide \\
\hline 1450 & $M$ & cion \\
\hline 1380 & $\omega$ & 0 \\
\hline 1260 & $M$ & \\
\hline 1090 & $\mu$ & \\
\hline 1020 & $M$ & \\
\hline Soo & 4 & \\
\hline$-\frac{850}{60}$ & Mue & wentatorin hand \\
\hline
\end{tabular}


IR REPORT

SAMPLE: ZUN 4 - AFB - SORBENT - FRACTION 1

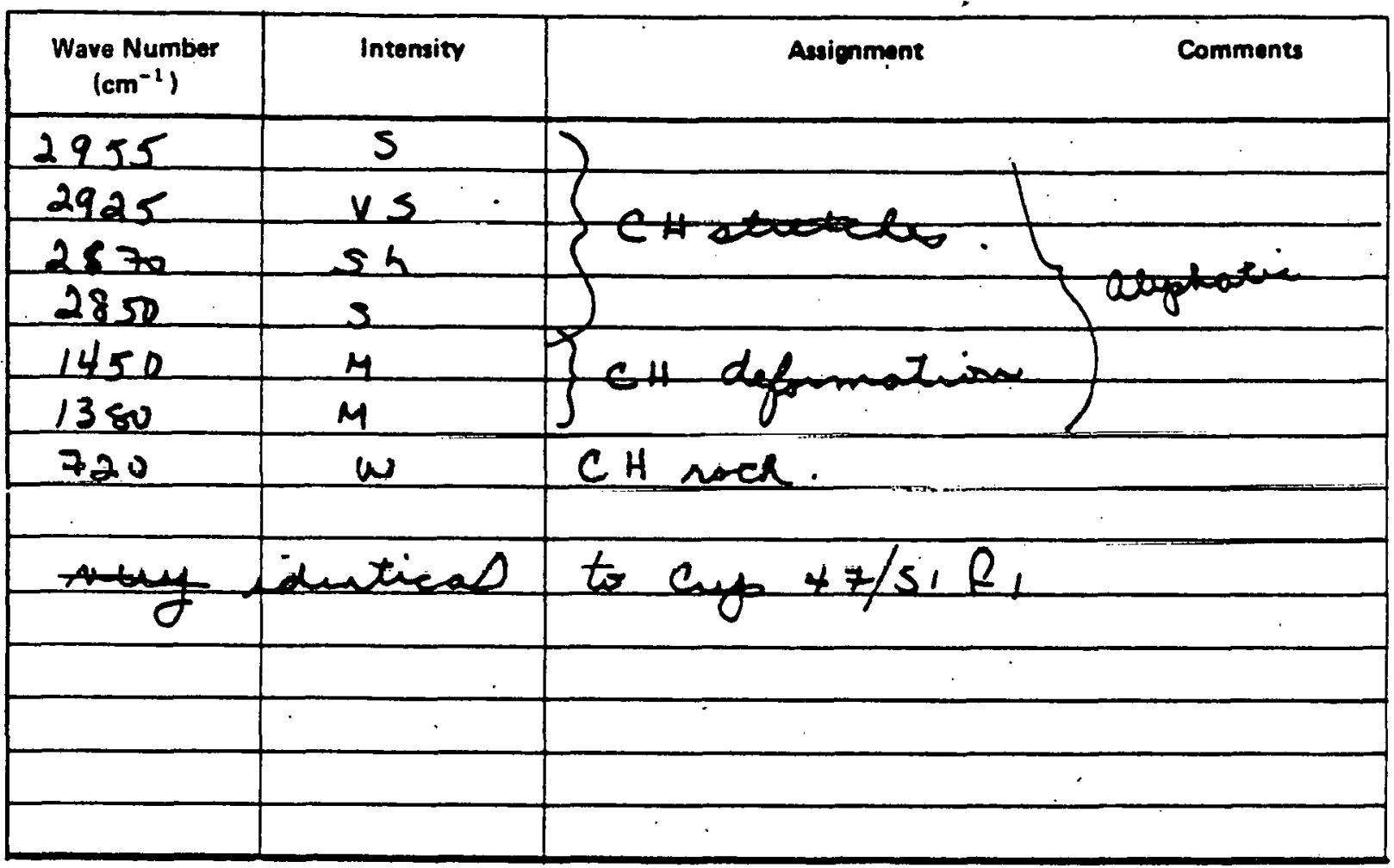

IR REPORT

SAMPLE: $\frac{\text { RUN } 4-A F B-\text { SORBENT - FRACTIONS 2-4 }}{\delta}$

\begin{tabular}{|c|c|c|}
\hline $\begin{array}{l}\text { Wave Number } \\
\left(\mathrm{cm}^{-1}\right)\end{array}$ & Intensity & Asolignmont \\
\hline $3025-3050$ & $M$ & aromaic CH thetes \\
\hline 2960 & 4 & \\
\hline 2025 & H. & Galigeaic C Heturen \\
\hline 2800 & M & \\
\hline 1600,1500 & $\omega$ & 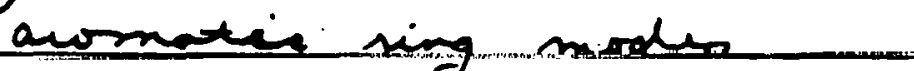 \\
\hline 1450,1380 & $m, \omega$ & $C^{N}$ defo \\
\hline 1260 & H & \\
\hline 1090,1030 & s & suexane \\
\hline $800^{\circ}$ & $\underline{s}$ & \\
\hline $900-650$ & $5, M$ & aromotic $C H$ eubletent \\
\hline & & \\
\hline & & \\
\hline
\end{tabular}


SAMPLE: RUN 4 - AFB - SORBENT - FRACTIONS 5-7

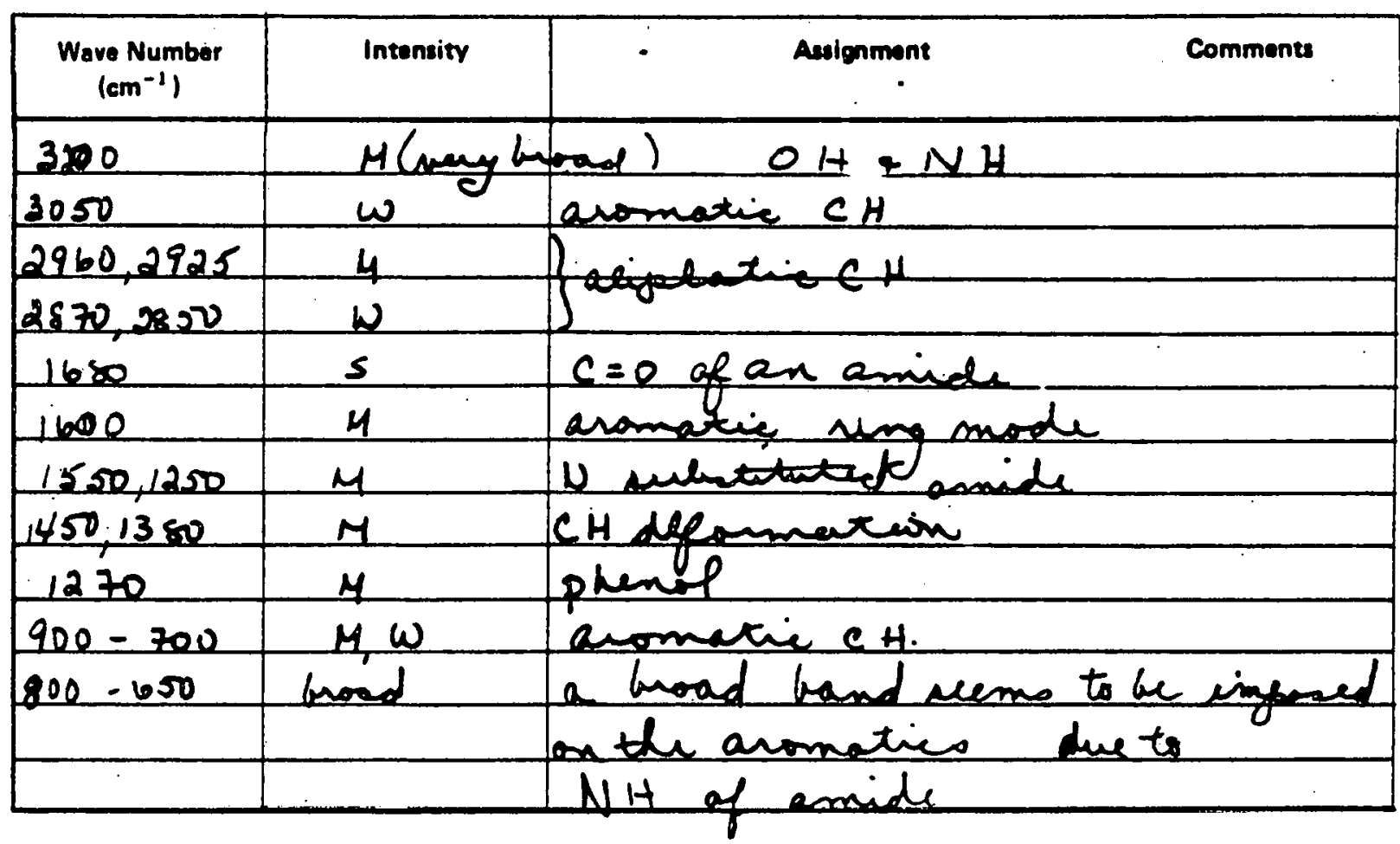

IR REPORT

SAMPLE: RUN 4 - AFB - CONDENSATE

$\gamma$

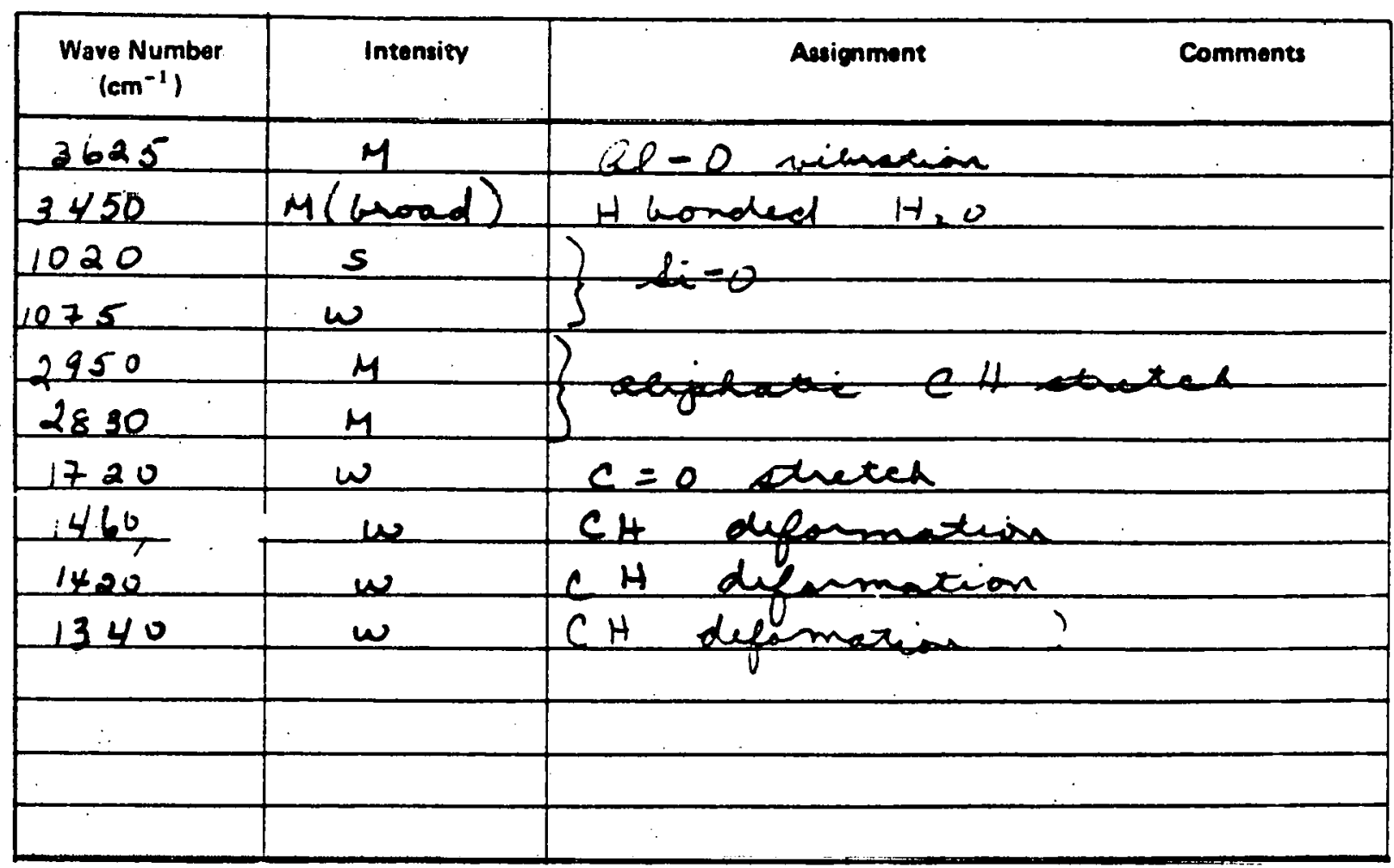


LAMS REPORT

SAMPLE: RIN 4 - AFB - FIITER

Major Categories

\begin{tabular}{|c|c|c|}
\hline Intenisity & \multicolumn{1}{|c|}{ Cotogory } & Mw Range \\
\hline $1 \phi \phi$ & ALIPHATIC HYDROCARBONS & - \\
\hline $1 \phi$ & ESTERS & $39 \phi$ \\
\hline $1 \phi$ & SILICONES & \\
\hline & & \\
\hline & & \\
\hline & & \\
\hline
\end{tabular}

Sub-Categories, Specific Compounds

\begin{tabular}{|c|c|c|c|}
\hline Intensity & Category & $\mathrm{m} / \mathrm{e}$ & Composition \\
\hline 10 & PHTHALATE, DOP TYPE & 390 & $\mathrm{C}_{24} \mathrm{H}_{38} \mathrm{O}_{4}$ \\
\hline & & & \\
\hline & & & . \\
\hline . & & & \\
\hline & & & \\
\hline & & & \\
\hline & & & \\
\hline & & & \\
\hline & & & \\
\hline & & & \\
\hline & & & \\
\hline . & & & \\
\hline & & & \\
\hline & & & \\
\hline & & & \\
\hline & & & \\
\hline & & & \\
\hline
\end{tabular}

\section{Other}


LRMS REPORT

SAMPLE: RIN 4 - AFB - SORBENT

Major Categories

\begin{tabular}{|c|c|c|}
\hline Intensity & Category & MW Range \\
\hline $1 \phi \varnothing$ & Fused ALTERnate, NoNALTERnate hydrdcarosuls & $<2 / 6$ \\
\hline $1 \theta 0$ & CARBOXYLIC ACIDS & 122 \\
\hline 10 & ALIPHATIC HYDROCARBONS & To 450 \\
\hline $1 \varnothing$ & $S / \angle 1 C$ ONES & $70 \sim 6 \phi \phi$ \\
\hline 18 & AROMATIC HYDROCARBONS & $23 \phi$ \\
\hline
\end{tabular}

Sub-Categories, Specific Compounds

\begin{tabular}{|c|c|c|c|}
\hline Intensity & Category & $m / e$ & Composition \\
\hline $10 \phi$ & 3 RING PAH(Anntracene /PHevantinent) & 178 & $C_{14} H_{10}$ \\
\hline 100 & BENZOIC ACD & 122 & $\mathrm{C}_{4} \mathrm{H}_{6} \mathrm{O}_{2}$ \\
\hline $1 \phi \phi$ & Phenyl Naphthatene & 204 & $C_{16} H_{12}$ \\
\hline 10 & 4 RING PAH (FuduantTHENE PYrenNe) & 202 & $C_{16} H_{10}$ \\
\hline 10 & ALKYL 3RING PAH & \multicolumn{2}{|c|}{$192-206 \mathrm{C}_{15} \mathrm{H}_{12}-\mathrm{C}_{16} \mathrm{H}_{14}$} \\
\hline 10 & DIHYDRO 3 RING PAH & $18 \phi$ & $\mathrm{C}_{14} \mathrm{H} / 2$ \\
\hline 10 & METHYL PHENYL NAPATARENE & $2 / 8$ & $\mathrm{C}_{17 \mathrm{H}_{14}}$ \\
\hline 10 & TEREPHENYL & $23 \phi$ & $\mathrm{C}_{18} \mathrm{H}_{14}$ \\
\hline & & & \\
\hline & & & \\
\hline & & & \\
\hline & & & \\
\hline & & & \\
\hline & & & \\
\hline & & & \\
\hline & & & \\
\hline & & & \\
\hline & & & \\
\hline
\end{tabular}

Other

iD. Alphatic Hydrocarbous To $\mathrm{m} / \mathrm{z} \sim 45 \varnothing$ 


\section{LRMS REPORT}

SAMPLE: SUN 4 - AFB - SORBENT - FRACTION 1

\section{Major Categories}

\begin{tabular}{|l|c|c|}
\hline Intensity & \multicolumn{1}{|c|}{ Catogory } & Miw Range \\
\hline $1 \phi \phi$ & ALIPHATLC HYDROCARBONS & $222 \tau_{0} 38 \phi$ \\
\hline & & \\
\hline & $\vdots$ & \\
\hline & & \\
\hline & & \\
\hline
\end{tabular}

Sub-Categories, Specific Compounds

\begin{tabular}{|l|l|l|l|}
\hline Intensity & Cotegory & $\mathrm{m} / \mathrm{c}$ & Composition \\
\hline & & & \\
\hline & & & \\
\hline & & & \\
\hline & & & \\
\hline & & & \\
\hline & & & \\
\hline & & & \\
\hline & & & \\
\hline & & & \\
\hline & & & \\
\hline & & & \\
\hline & & & \\
\hline & & & \\
\hline & & & \\
\hline & & & \\
\hline & & & \\
\hline
\end{tabular}




\section{LRMS REPORT}

SAMPLE: RUN 4 - AFB - SORBENT - FRACTIONS 2-4

Major Categories

\begin{tabular}{|c|c|c|c|c|}
\hline Intensity & \multicolumn{3}{|c|}{ Category } & MW Range \\
\hline $1 \phi \phi$ & \multicolumn{3}{|c|}{ ALIPHATIC HIDRDCARBOUL } & To $\sim 4 \phi \phi$ \\
\hline 10 & FUSED ALTERUATE, & NON ALTERUATE & HYDRocoreous & $<216$ \\
\hline 10 & $"$ & " & $"$ & $>216$ \\
\hline & . & & & \\
\hline & & & & \\
\hline & & & & \\
\hline
\end{tabular}

Sub-Categories, Specific Compounds

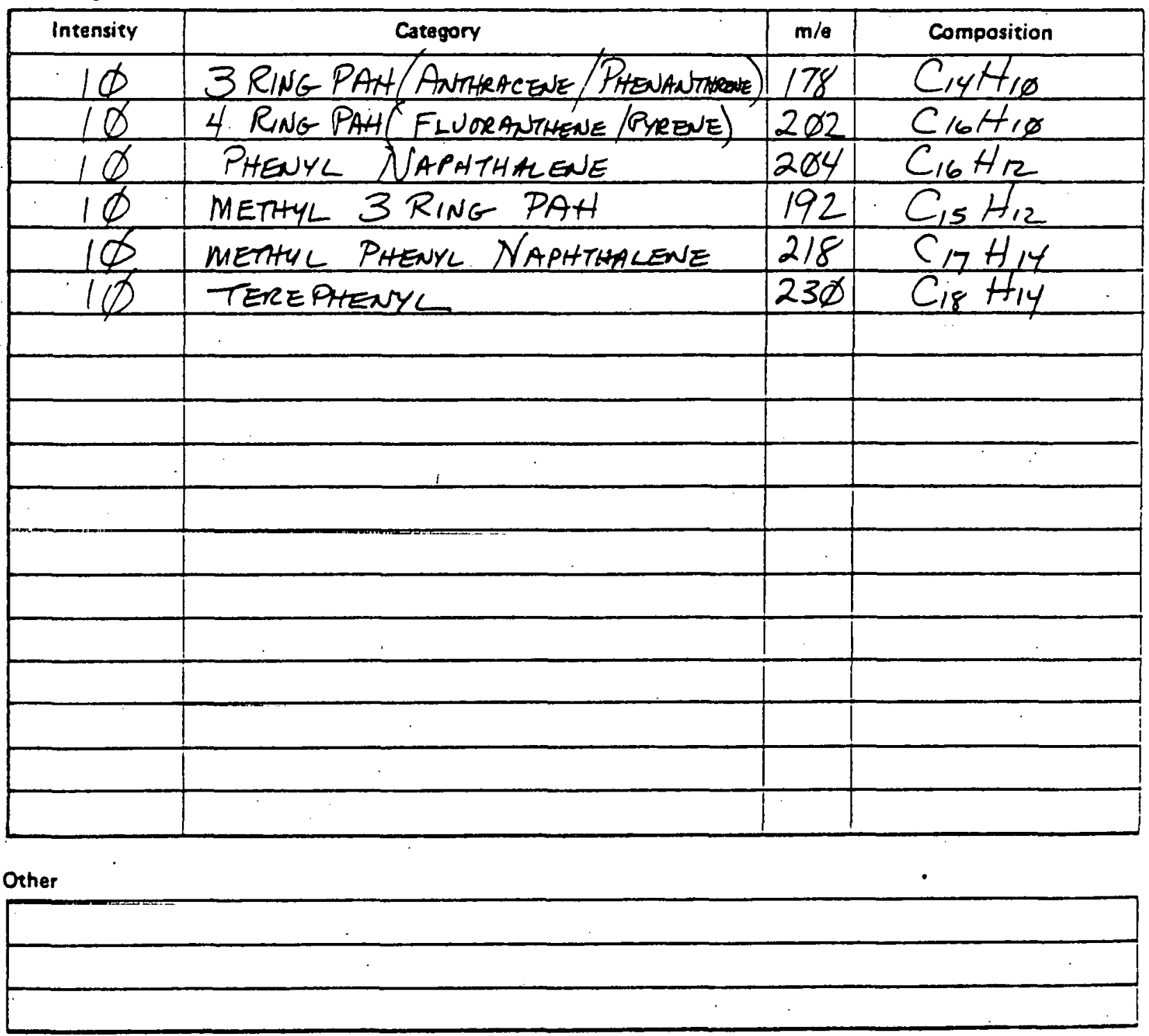


LRMS REPORT

SAMPLE: _ RUN 4 - AFB - SORBENT - FRACTIONS 5-7

Major Categories

\begin{tabular}{|c|c|c|}
\hline Intensity & Category & MW Ranga \\
\hline $1 \phi \phi$ & CARBOKYLIC ACIDS & 122 \\
\hline $10 \phi$ & ALIPHATIC COMPOUNDS ${ }^{*}$ & NoT IDENTIFIAC \\
\hline$\phi$ & ESTERS & 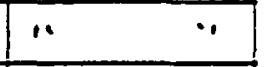 \\
\hline 10 & UNAASSIFIED & $13 \phi-3 \phi \phi$ \\
\hline 1 & KETONES & 180 \\
\hline
\end{tabular}

Sub-Categories, Specific Compounds

\begin{tabular}{|c|c|c|c|}
\hline Intensity & Category & $m / a$ & Composition \\
\hline$\phi \varnothing$ & BENZOIC ACID & 122 & $\mathrm{C}_{7} \mathrm{H}_{6} \mathrm{O}_{2}$ \\
\hline 10 & \multicolumn{3}{|c|}{ PHTIHALATES, NOTSPECIFICALLY IDENTIFIABLEE. } \\
\hline 1 & FLUORENONE & $18 \varnothing$ & $\mathrm{C}_{13} \mathrm{H}_{8} \mathrm{O}$ \\
\hline & & & \\
\hline & & & \\
\hline & & & \\
\hline & & & \\
\hline & & & \\
\hline & - & & \\
\hline & & & \\
\hline & & & \\
\hline & & & \\
\hline & & & \\
\hline & & & \\
\hline & & & \\
\hline & & & \\
\hline & & & \\
\hline & & & \\
\hline
\end{tabular}

Orher

* Aliphatic Compounos: The spectra show only the $C_{3}$ to $-C_{10}$ Portion of the MOLECULES - COOLD BE KETONES, ALCHOLS, or HYDROCARBON CONTAMINATION. 
LRMS REPORT

SAMPLE: _ RUN 4 - AFB - CONDENSATE

Major Categories

\begin{tabular}{|c|c|c|}
\hline Intensity & Category & MW Range \\
\hline 100 & ESTERS & 390 \\
\hline$\perp$ & FUSED ALTERNATE NOU ALTERUATE Hyrrocarbons & $<216$ \\
\hline 1 & AROMATIC HYDROCARBDUS & 230 \\
\hline 1 & Fused Alternate, Non ALternate Hydreocarbons & $>216$ \\
\hline & & \\
\hline
\end{tabular}

Sub-Categories, Specific Compounds

\begin{tabular}{|c|l|c|c|}
\hline Intensity & \multicolumn{1}{|c|}{ Category } & $\mathrm{m} / \mathrm{s}$ & Composition \\
\hline 100 & PHTHALATE & 390 & $\mathrm{C}_{24} \mathrm{H}_{38} \mathrm{O}_{4}$ \\
\hline 1 & 4 RING PAH (FLORANTHENE, PYRENE) & 202 & $\mathrm{C}_{16} \mathrm{H}_{10}$ \\
\hline 1 & PHENYL NAPATHALENE & $20^{\prime}$ & $\mathrm{C}_{16} \mathrm{H}_{12}$ \\
\hline 1 & TEREPHENYL & 230 & $\mathrm{C}_{18} \mathrm{H}_{14}$ \\
\hline 1 & METHYL PHENYL NAPHTHALENE & $2 / 8$ & $\mathrm{C}_{17} \mathrm{H}_{14}$ \\
\hline & & & \\
\hline & & & \\
\hline & & & \\
\hline & & & \\
\hline & & & \\
\hline & & & \\
\hline & & & \\
\hline & & & \\
\hline & & & \\
\hline & & & \\
\hline
\end{tabular}

Other 
in MERORT

SAMPLE:

RUN 5 - SAA - FILTER

\begin{tabular}{|c|c|c|}
\hline $\begin{array}{l}\text { Wave Number } \\
\left(\mathrm{em}^{-1}\right)\end{array}$ & Intensity & Comments \\
\hline 3400 & lerod & ount of $\mathrm{OH}$ \\
\hline 2960 & $M$ & \\
\hline 2920 & 5 & aliphatic CH streh \\
\hline 2850 & $\dot{M}$ & \\
\hline 1450 & $M$ & hin \\
\hline 1380 & $\omega$ & \\
\hline 1260 & $M$ & \\
\hline 1.090 & M & esfe \\
\hline 1020 & $\mu$ & $\gamma$ \\
\hline 800 & $M$ & $\dot{5}$ \\
\hline & & \\
\hline & & $\cdot$ \\
\hline
\end{tabular}

\section{IR REPORT}

SAMPLE:

RUN 5 - SAA - SORBENT

\begin{tabular}{|c|c|c|}
\hline $\begin{array}{l}\text { Wave Number } \\
\left(\mathrm{em}^{-1}\right)\end{array}$ & Intensity & Assignmont \\
\hline 3300 & bnood & $\mathrm{NH}$ \\
\hline 2960 & $s$ & 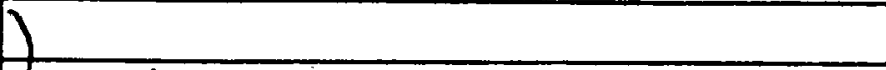 \\
\hline 2920 & 5 & I a hipatie CH streted \\
\hline 2850 & M & $\mathcal{L}$ \\
\hline 3050 & $w$ & awomatic CH \\
\hline 1700 & $M$ & $c=0$ af amide. \\
\hline 1600 & $\omega$ & $\gamma$ \\
\hline 1550 & $\omega$ & amide $N \mathrm{H}$ \\
\hline 1450,1380 & $M, \omega$ & $C_{H}$ deformacion \\
\hline 1260 & $M$ & Z \\
\hline 1090 & $M$ & I tilotane \\
\hline 1020 & $y$ & \\
\hline 800 & & \\
\hline $850 \rightarrow 600$ & Hw & Qromatic nubutition fando \\
\hline
\end{tabular}


IR REPORT

SAMPLE:__ RUN 5 - SAP - CONDENSATE

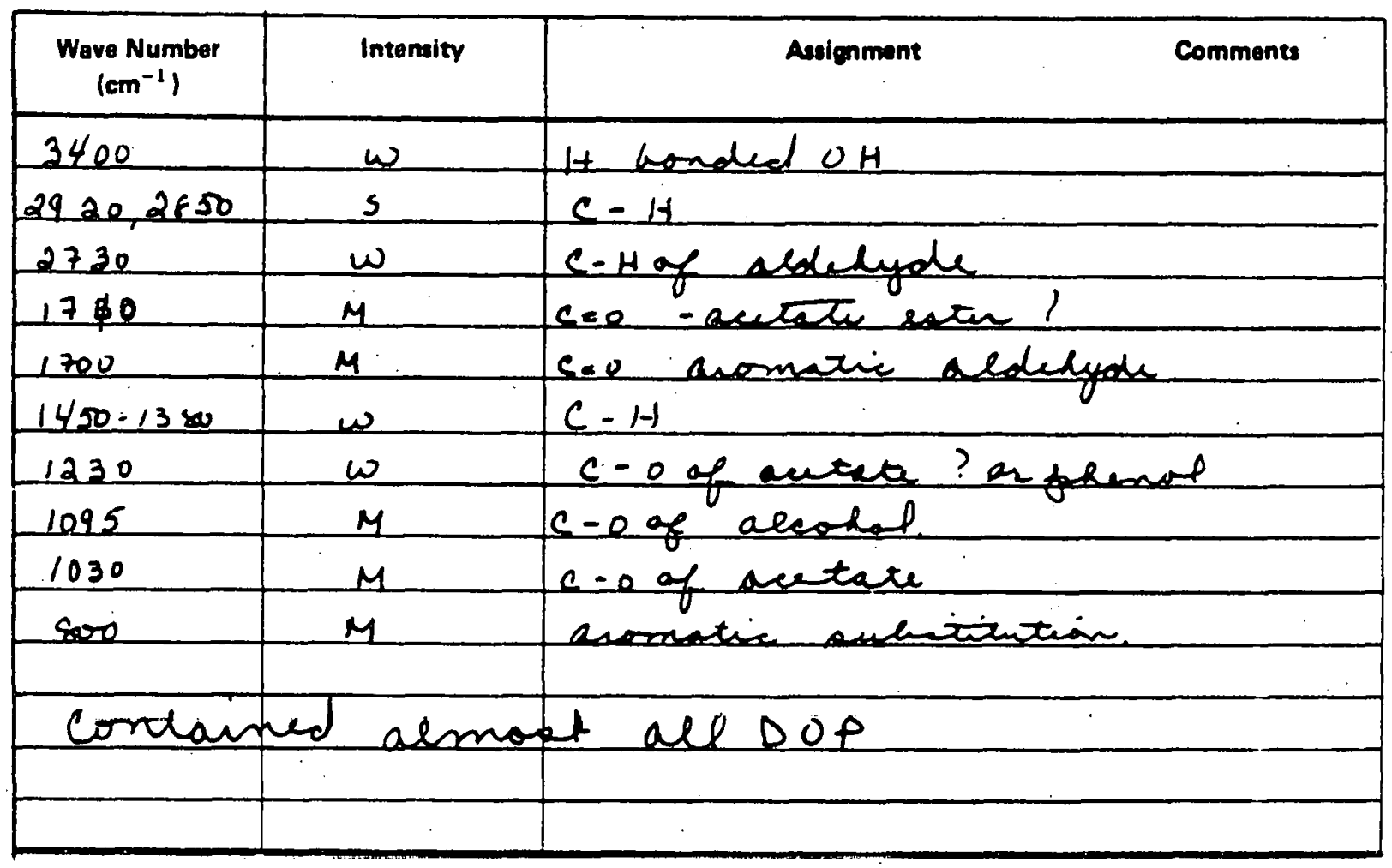

79 
LRMS REPORT

SAMPLE: RIN 5 - SAA - FILTER

Major Cotegories

\begin{tabular}{|c|c|c|}
\hline Intensity & Cotegory & MW Range \\
\hline $1 \phi \phi$ & ALIPHATIC HYDROCARBONV & $>35 \varnothing$ \\
\hline 10 & ESTERS & - \\
\hline $1 \varnothing$ & SILICONES & $=$ \\
\hline 1 & Fused Alternate, non Altornate hydrod carbons & $<2 / 6$ \\
\hline & & \\
\hline
\end{tabular}

Sub-Categories, Specific Compounds

\begin{tabular}{|c|c|c|c|}
\hline Intansity & Category & $m / n$ & Composition \\
\hline $1 \varnothing$ & \multicolumn{3}{|c|}{ PHTHALATE, NOT SPETHCALLY IDEUTIFIASLE } \\
\hline 1 & 4 RING PAH (Fworeatione/AYRENE) & $2 \phi_{2}$ & $C_{16}+16$ \\
\hline 1 & 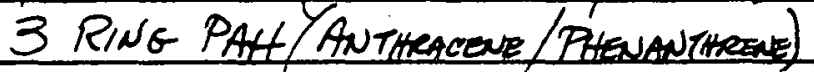 & 178 & Cuttix \\
\hline & & & $\cdot$ \\
\hline & & & \\
\hline & & 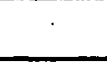 & \\
\hline - & & & \\
\hline & & & \\
\hline & & & \\
\hline & & & \\
\hline & & & \\
\hline & & & \\
\hline & & & \\
\hline & & & \\
\hline & & & \\
\hline & & & \\
\hline & & & \\
\hline & & & \\
\hline
\end{tabular}

\section{Other}


LRMS REPORT

SAMPLEE:_RUN 5 - SAA - SORBENT

Major Categories

\begin{tabular}{|c|c|c|}
\hline Intensity & Category & MW Range \\
\hline $1 \phi \varnothing$ & ALIPHATIC HYDROCARBONS & To $\sim 400$ \\
\hline $10 \phi$ & Fused ALTERNATE, NON aLTERNATE HYDROCMRBOUS & $<2 / 6$ \\
\hline $1 \phi \varnothing$ & CARBOXYLIC ACIDS & $122-2 \phi \phi$ \\
\hline $1 \varnothing \varnothing$ & ESTERS & - \\
\hline $1 \varnothing$ & SILICONES & $10070>500$ \\
\hline $1 \varnothing$ & Fused ALternate, noN ALternate Hydrocarsons & $>216$ \\
\hline
\end{tabular}

Sub-Categories, Specific Compounds

\begin{tabular}{|c|c|c|c|}
\hline Intensity & Category & $\mathrm{m} / \mathrm{e}$ & Composition \\
\hline $1 \phi \phi$ & BEUZOIC ACID & 122 & $\mathrm{C}_{7} \mathrm{H}_{6} \mathrm{O}_{2}$ \\
\hline $1 \phi \phi$ & PHTHALATE, DOP TYPE & 390 & $\mathrm{C}_{24} \mathrm{H}_{38} \mathrm{O}_{4}$ \\
\hline $1 \phi \varnothing$ & 3 Ring PAH (Anthracene /Phengantrirat) & 178 & C14 H10 \\
\hline $1 \varnothing$ & PHENYL NAPATHALENE & 204 & $\mathrm{C}_{16} \mathrm{H}_{12}$ \\
\hline 10 & 4 RING PAH (Funorantitene (PYRENe) & $2 \phi_{2}$ & $C_{16}+116$ \\
\hline 10 & ALKYL 3 RING PAH & $192-204$ & $\mathrm{C}_{15} \mathrm{H}_{12}-\mathrm{C}_{16} \mathrm{H}_{14}$ \\
\hline 10 & TEREPHENYL & $23 \phi$ & $\mathrm{C}_{18} \mathrm{H}_{14}$ \\
\hline 10 & 4 RING PAHA (CHRYSENE, ETC.) & 228 & $\mathrm{C}_{18} \mathrm{H}_{12}$ \\
\hline 10 & METHUL PHEUYL Naphthaleve & 218 & $\mathrm{C}_{17} \mathrm{H}_{14}$ \\
\hline 10 & UNDECANOTC & 186 & $\mathrm{C}_{11} \mathrm{H}_{22} \mathrm{O}_{2}$ \\
\hline 10 & DODECANOIC ACID & $2 \phi \phi$ & $\mathrm{C}_{12} \mathrm{H}_{24} \mathrm{O}_{2}$ \\
\hline & & & \\
\hline & & & \\
\hline & & & \\
\hline & & & \\
\hline & & & \\
\hline & & & \\
\hline
\end{tabular}

Other

10 S/LICNES, $\mathrm{m} / \mathrm{z} \sim 10 \phi$ TO $>50 \phi$ 
LRMS REPORT

SAMPLE:

RUN 5 - SAA - CONDENSATE

Major Categories

\begin{tabular}{|c|l|c|}
\hline Intensity & \multicolumn{1}{|c|}{ Category } & MW Range \\
\hline $10 \phi$ & ESTERS & $39 \phi$ \\
\hline $1 \phi$ & SILICONES & $>4 \phi \varnothing$ \\
\hline 1 & FUSED ALTERNATE, NON ALTERNATE HYDROCARBONS & $<216$ \\
\hline 0.5 & HETERCYCLIC NTRDGEJ COMPOUNDS & 135 \\
\hline 0.5 & HETEROCYCLIC SULFUR COMPOUNDS & 135 \\
\hline & & \\
\hline
\end{tabular}

Sub-Catogories, Spooific Compounds

\begin{tabular}{|c|c|c|c|}
\hline Intensity & Category & $\mathrm{m} / \mathrm{e}$ & Composition \\
\hline $1 \phi \phi$ & PHPPHALATE, DOP THPE & 390 & $\mathrm{C}_{24} \mathrm{H}_{38} \mathrm{O}_{4}$ \\
\hline 1 & 3 RING PAH (ANTHRACENE/PHENANTHEER) & 178 & $C_{14} H_{10}$ \\
\hline 1 & BENZOTHIAZORE & 135 & $\mathrm{C}_{7} \mathrm{H}_{5} \times \mathrm{NS}$ \\
\hline 1 & PHENYL NAPATHALENE & 204 & $C_{16} H_{12}$ \\
\hline 1 & 4 RING PAH (FZuoranthene ( PYRENE) & $2 \phi 2$ & $C_{16} H_{10}$ \\
\hline & & & \\
\hline & & & \\
\hline & & & \\
\hline & & & \\
\hline & & & \\
\hline & & & \\
\hline & & & \\
\hline & & & \\
\hline & & & \\
\hline & & & \\
\hline & & & \\
\hline & & & \\
\hline & & & \\
\hline
\end{tabular}

Other

10 Sulcoves, to $\mathrm{m} / \mathrm{z}>4 \varnothing \varnothing$ 
IR REPORT

SAMPLE:

RUN 6 - SAA - FILTER

\begin{tabular}{|c|c|c|}
\hline $\begin{array}{l}\text { Wave Number } \\
\left(\mathrm{cm}^{-1}\right)\end{array}$ & Intensity & Aselignmont \\
\hline 2960 & $M$ & 2 \\
\hline 2925 & $s$ & Y aliphatic CHatuted \\
\hline 2850 & $M$ & J \\
\hline 1450,13500 & $\omega$ & c.tt defenmation \\
\hline 1260,1070 & $\omega$ & $\sin ^{0}$ \\
\hline 1020,800 & $\omega$ & $\zeta$ \\
\hline 1120 & $\omega$ & c-oestu \\
\hline 1735 & $\omega$ & $c=0$ esten \\
\hline & & \\
\hline & & \\
\hline & & \\
\hline & & \\
\hline
\end{tabular}

IR REPORT

SAMPLE:

RUNT 6 - SAA - SORBENT

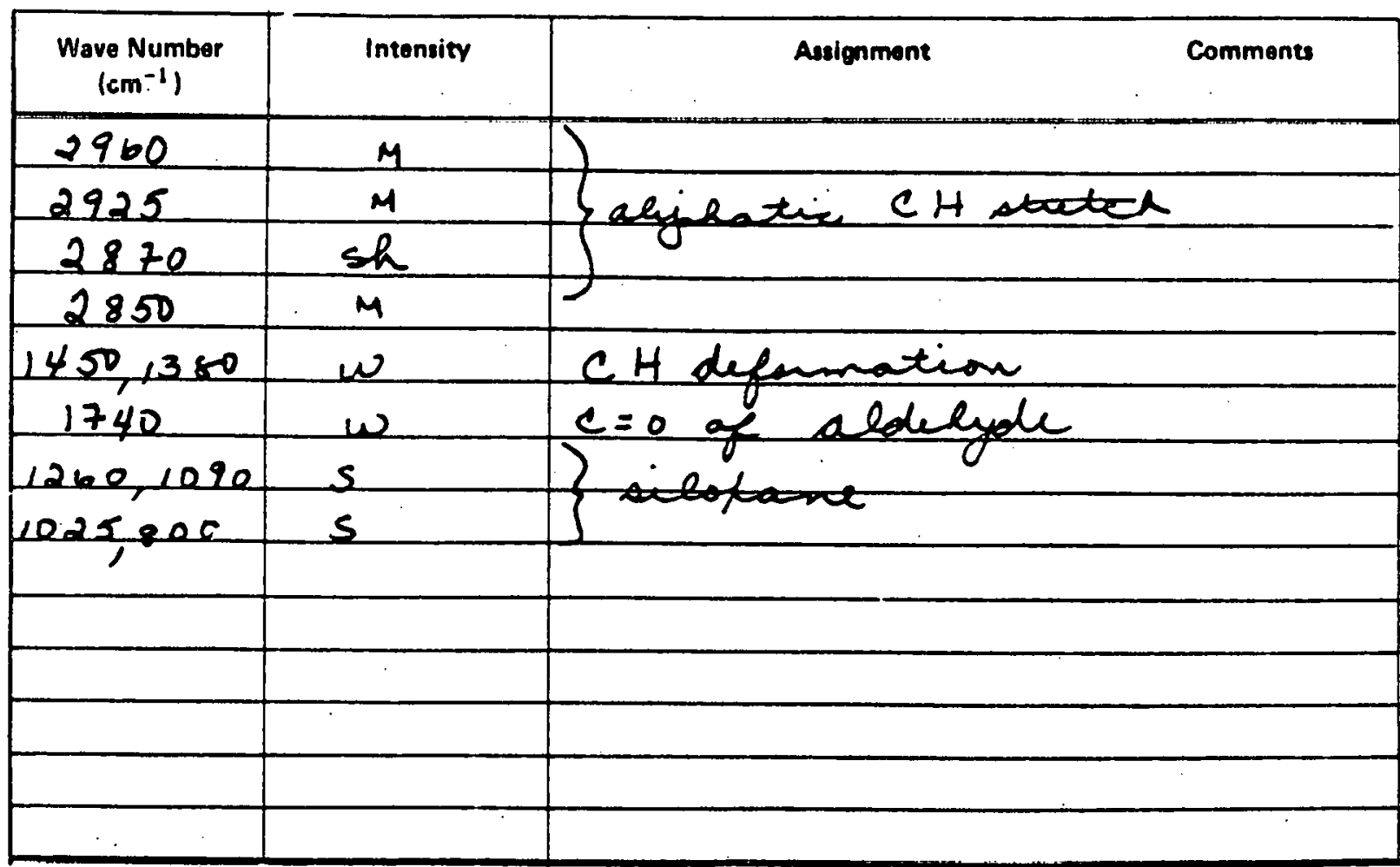




\section{IA REPORT}

SAMPLE: RUN 6 - SAA - CONDENSATE

\begin{tabular}{|c|c|c|}
\hline $\begin{array}{l}\text { Wave Number } \\
\left(\mathrm{cm}^{-1}\right)\end{array}$ & Intensity & Acsignment \\
\hline 2960 & $m$ & L \\
\hline 2930 & $H$ & I assiatatic CH \\
\hline 2850 & $M$ & $\mathrm{~J}$ \\
\hline 1725 & $\underline{s}$ & $c=0$ of a ketome \\
\hline 1435 & $\omega$ & Af head cant see 1380 , Then tar coned \\
\hline 1275,1260 & $s$ & Salsobcc-ce. \\
\hline 1230 & $M$ & $\mathrm{CH}_{2} \mathrm{CP}$ ? \\
\hline & & \\
\hline & & \\
\hline & & ' \\
\hline & & \\
\hline & & \\
\hline
\end{tabular}


LRMS REPORT

SAMPLE:___ RUN 6 - SAA - FILTER

Major Categories

\begin{tabular}{|c|l|c|}
\hline Intensity & \multicolumn{1}{|c|}{ Category } & MW Range \\
\hline 100 & ALIPHATIC HYDROCARBONS & To 400 \\
\hline 10 & ESTERS & 390 \\
\hline 10 & SILICONES & - \\
\hline 10 & HETEROCYCLIC NITROGEN COMPO UNDS & $129-157$ \\
\hline 10 & FUSED ALTERNATE, NONALTER NATE HYDROCARBOWS & 2216 \\
\hline 1 & UNCLASSIFIED & 70350 \\
\hline
\end{tabular}

Sub-Categories, Specific Compounds

\begin{tabular}{|c|c|c|c|}
\hline Intensity & Category & $\mathrm{m} / \mathrm{e}$ & Composition \\
\hline 10 & \multicolumn{3}{|c|}{ PHTHALATES, Not SPECIFICALLY IDENTIAKabLE } \\
\hline 10 & \multicolumn{3}{|c|}{ SILICONES $207,236,281$} \\
\hline 10 & \multicolumn{3}{|c|}{ QUINDLINE AND $\mathrm{C}_{1} \mathrm{C}_{2}$ qUINDLNES $129-157 \mathrm{CqH}_{7} \mathrm{~N}-\mathrm{C}_{11} H_{11} \mathrm{~N}$} \\
\hline 10 & 3 Ring Payt (Anthracteve, Phenanthreene) & 178 & $\mathrm{C}_{14} \mathrm{H}_{10}$ \\
\hline 10 & 4 Ring PaA (Fluorantrane, Pyrene) & 202 & $C_{16} H_{10}$ \\
\hline 10 & METHYL 3 RING PAH & 192 & $\mathrm{C}_{15} \mathrm{H}_{12}$ \\
\hline & & & \\
\hline & & & \\
\hline & & & \\
\hline & & & \\
\hline & & & \\
\hline & & & \\
\hline & & & \\
\hline & & & \\
\hline & & & \\
\hline & & & \\
\hline & & & \\
\hline
\end{tabular}

Orher

1 (EACH) MUCH OTHER TRACE LEVEL WATERIAL BETWEEN $\mathrm{m} / \mathrm{z} / 50$ AND 350Appears to contain porycycluc materiar as wel as alipic. 
LRMS REPORT

SAMPLE:_RUN 6 - SAA - SORBEIT

Major Categories

\begin{tabular}{|c|c|c|}
\hline intensity & Category & MW Range \\
\hline $10 \varnothing$ & CARBOXYLIC & $122-200$ \\
\hline $10 \phi$ & FUSED ALTERNATE, NOU ALTERNATE HYDRUCARSSIS & $<216$ \\
\hline 10 & $S / L I C O N E S$ & $70>5 p d$ \\
\hline $1 \phi$ & AMINES & 327 \\
\hline $1 \varnothing$ & FUSED ALTERNATE, NONALTERNATE HYOROCARBOULS & $\geq 216$ \\
\hline $1 \varnothing$ & UNCLASSIFIED & $100-300$ \\
\hline
\end{tabular}

Sub-Categories, Specific Compounds

\begin{tabular}{|c|c|c|c|}
\hline Intensity & Caregory & $\mathrm{m} / \mathrm{e}$ & Composition \\
\hline $1 \phi \phi$ & BEUZOIC & 122 & $\mathrm{C}_{7} \mathrm{H}_{6} \mathrm{O}_{2}$ \\
\hline $10 \varnothing$ & 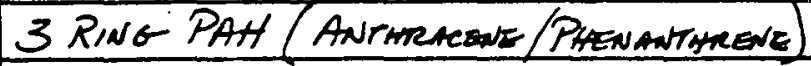 & 178 & $C_{14} H_{10}$ \\
\hline $1 \phi \phi$ & PHENYL NAPHTHALENE & $2 \not 4$ & $\mathrm{C}_{16} \mathrm{H} / 2$ \\
\hline $1 \varnothing$ & 4 RING PAHT (Fiwdranthene/PYRENE) & $2 \phi 2_{2}$ & $C_{16} A_{10}$ \\
\hline 10 & ALKYL 3 RING PAH & $192-296$ & $\mathrm{C}_{15} \mathrm{H}_{12}-\mathrm{C}_{16} \mathrm{H}_{14}$ \\
\hline 10 & TRIBROMO ANILINE & 327 & $\mathrm{C}_{6} \mathrm{H}_{4} \mathrm{Br}_{3} \mathrm{~N}$ \\
\hline 10 & mETHYL PHENYL NAPHTHALENE & 218 & $\mathrm{C}_{17} \mathrm{H}_{14}$ \\
\hline 10 & TEREPHENYL & $23 \phi$ & $\mathrm{C}_{18} \mathrm{H}_{14}$ \\
\hline 10 & $4 R_{N G G}$ PAHA (eY. CHRYISNE, ETC.) & 228 & $\operatorname{Cog} A_{12}$ \\
\hline 10 & DODECANOIC ACID & $2 \phi \phi$ & $\mathrm{C}_{12} \mathrm{H}_{24} \mathrm{O}_{2}$ \\
\hline & & & \\
\hline & & & \\
\hline & & & \\
\hline & & & \\
\hline & & & \\
\hline & & & \\
\hline & & & \\
\hline
\end{tabular}

Orher

$1 \phi$ SILICONES To $\mathrm{m} / \mathrm{z}>5 \phi \phi$
10 UNCLASSIFIED, $\mathrm{m} / \mathrm{z} 10 \phi$ TO $3 \phi \phi$


SAMPLE: RUN 6 - SAA - CONDENSATE

\section{Major Categories}

\begin{tabular}{|c|c|c|}
\hline Intenaity & \multicolumn{1}{|c|}{ Cotegory } & MW Range \\
\hline $1 \varnothing \varnothing$ & ESTERS & $222-39 \varnothing$ \\
\hline & & \\
\hline & & \\
\hline & & \\
\hline & & \\
\hline & & \\
\hline
\end{tabular}

\section{Sub-Cotegories, Specific Compounds}

\begin{tabular}{|c|c|c|c|}
\hline Intensity & Category & $\mathrm{m} / \mathrm{e}$ & Composition \\
\hline $1 \phi \phi$ & PHTHALATE, DOP TYPE & 390 & $\mathrm{C}_{24} \mathrm{H}_{38} \mathrm{O}_{4}$ \\
\hline 16 & DIETHLL TEXEPHTHALATE & 222 & $\mathrm{C}_{12} \mathrm{~A}_{14} \mathrm{O}_{4}$ \\
\hline & & & . \\
\hline & & & \\
\hline & & & \\
\hline & & & \\
\hline & & & \\
\hline & & & . \\
\hline & & & \\
\hline . & & & \\
\hline . & & & \\
\hline & & & \\
\hline & & & \\
\hline & & & \\
\hline . & & & \\
\hline & & & \\
\hline & & & \\
\hline
\end{tabular}

\section{Other}


IR REPORT

SAMPLE:

RLN 7 - SAA - FIITER

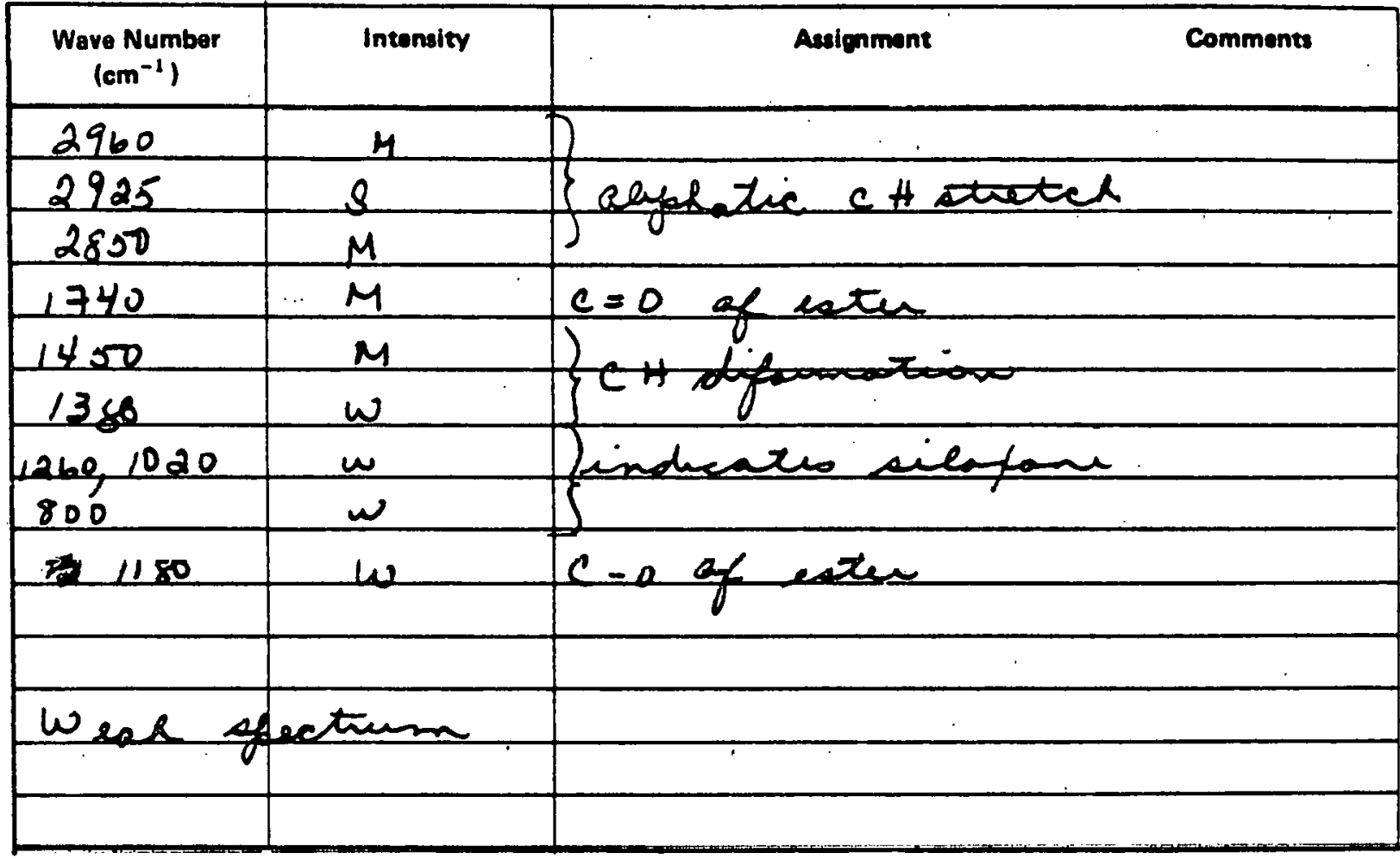

IR REPORT

SAMPLE: $\quad$ RUN 7 - SAA - SORBENT

\begin{tabular}{|c|c|c|}
\hline $\begin{array}{l}\text { Wave Number } \\
\left(\mathrm{cm}^{-1}\right)\end{array}$ & Intensity & Assignment \\
\hline 3400 & lmoad & OH \\
\hline 2960 & $s$ & 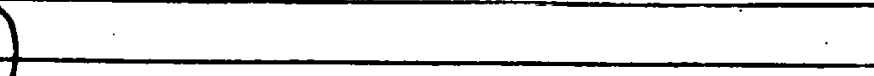 \\
\hline 2930 & $s$ & Teyolatie CH struel \\
\hline $2<75$ & $M$ & \\
\hline 2860 & $M$ & ${ }^{2}$ \\
\hline$, \$ 50,1380$ & $M$ & CH defomation \\
\hline 1725 & $M$ & $c=0$ of ester \\
\hline 1260,1180 & $\omega$ & $c-0$ \&e estu \\
\hline 1040 & $\omega$ & 10 of alcokol \\
\hline & & \\
\hline & & \\
\hline & & \\
\hline & & \\
\hline
\end{tabular}


SAMPLE: RUN 7 - SAA - SORBENT - FRACTION 1

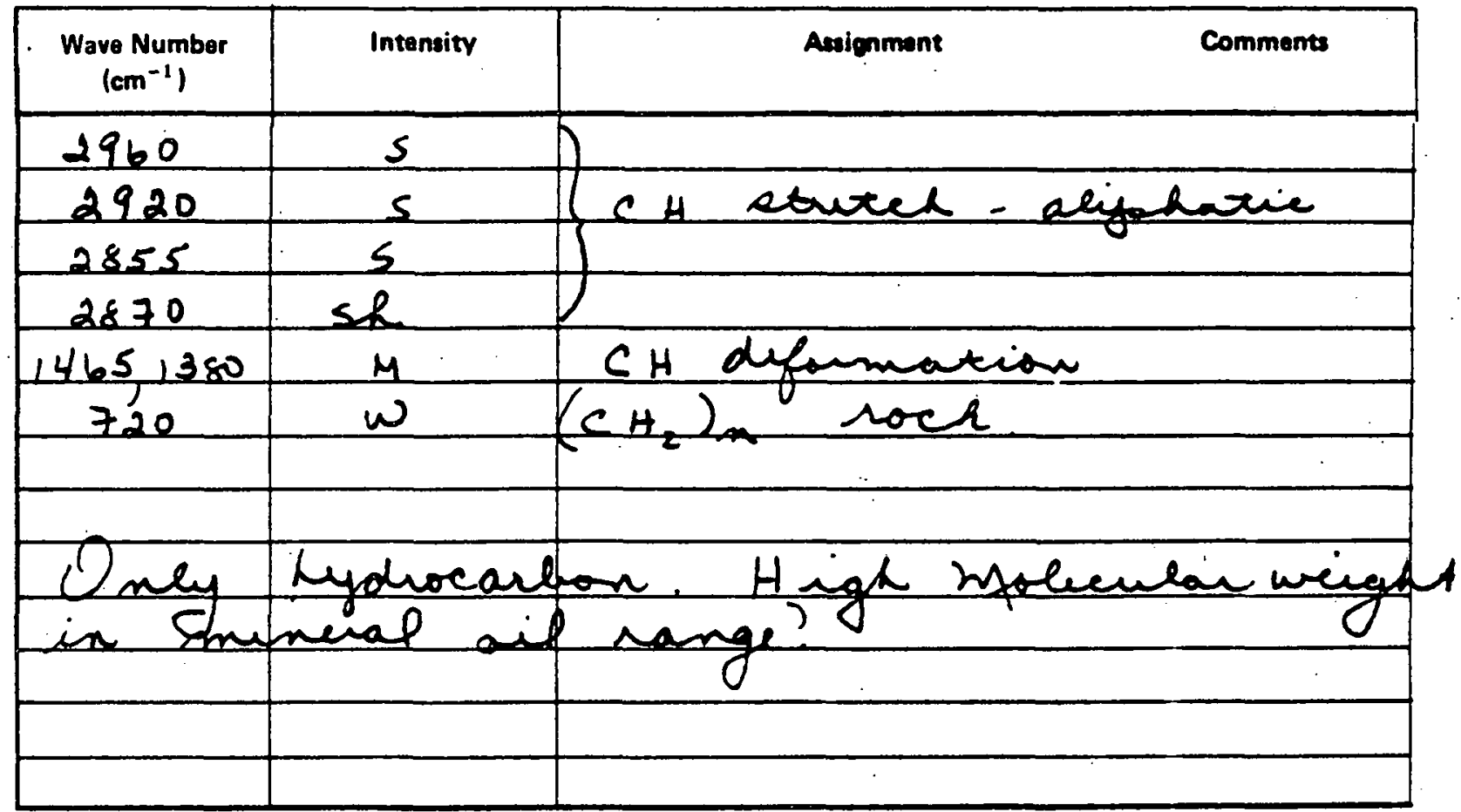

IR REPORT

SAMPLE: $\quad$ RUN 7 - SAA - SORBENT - FRACTIONS 2-4

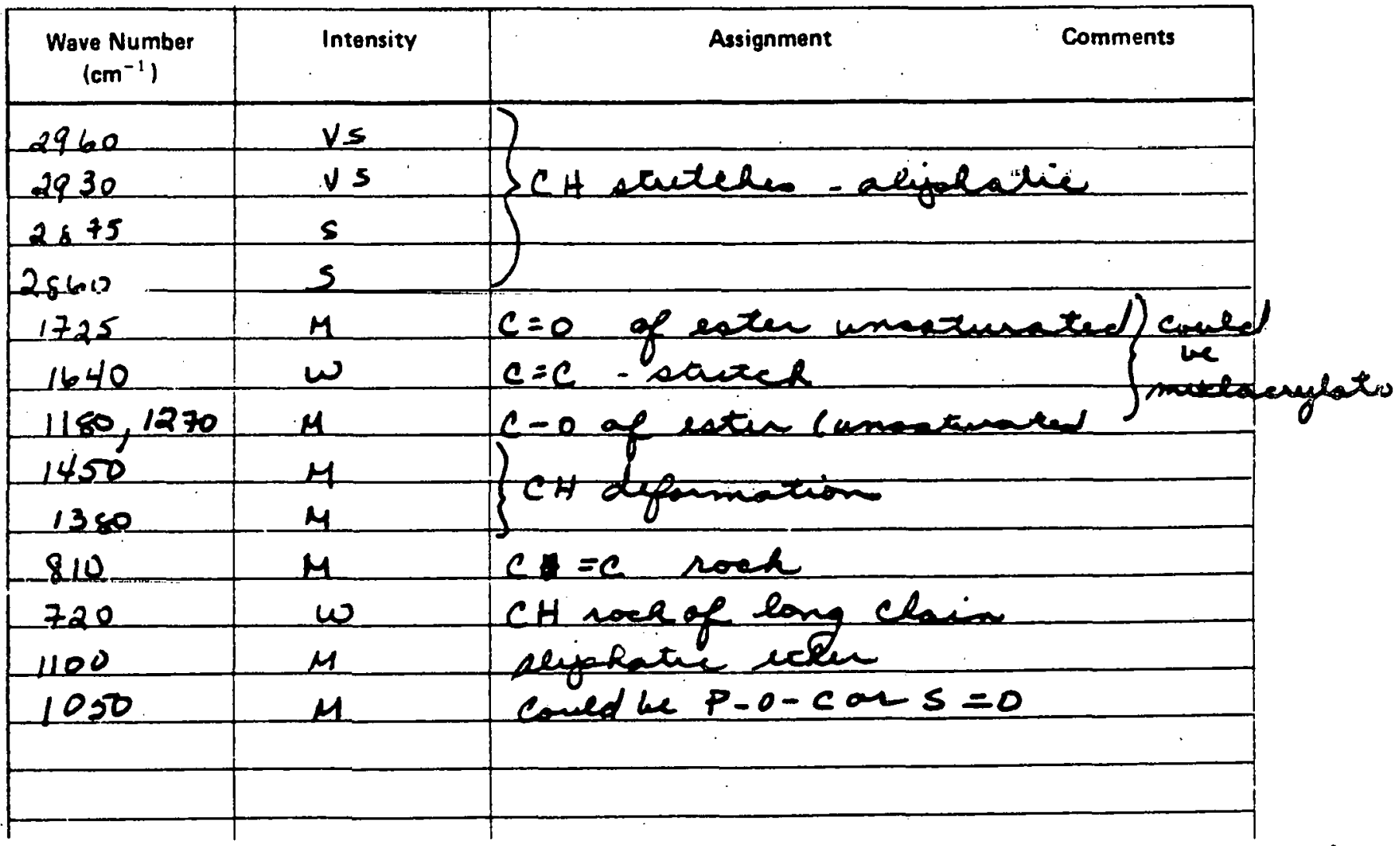


IR REPOR'T

SAMPLE:

RUN 7 - SAA - SORBENT - FRACTIONS 5-7

\begin{tabular}{|c|c|c|c|}
\hline $\begin{array}{l}\text { Wave Number } \\
\left(\mathrm{cm}^{-1}\right)\end{array}$ & Intensity & Ascignment & Comments \\
\hline 3300 & bood wand & $\mathrm{OH}$ & \\
\hline 2960 & $\mathbf{s}$ & ) & \\
\hline 2925 & $s$ & CH thenes & \\
\hline 2870 & $M$ & & \\
\hline 2850 & 4 & 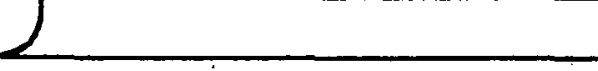 & \\
\hline 1725 & $s$ & $c=0$ of hetone & \\
\hline 1400 & 4 & & \\
\hline 2380 & $M$ & & \\
\hline 3000 & $\omega$ & $c=c$ & \\
\hline iwe & $M($ burad) & $c=0$ of $2^{\circ}$ alcohed & \\
\hline & & & \\
\hline & & & \\
\hline & & & \\
\hline
\end{tabular}

IR REPORT

SAMPLE:

RUN 7 - SAA - CONDENSATE

\begin{tabular}{|c|c|c|c|}
\hline $\begin{array}{l}\text { Wave Number } \\
\left(\mathrm{cm}^{-1}\right)\end{array}$ & Intensity & Acoignment & Comments \\
\hline 3625 & $M$ & $Q P-0$ & \\
\hline-1075 & $\omega$ & 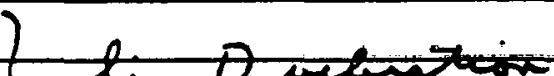 & \\
\hline 1220 & $M$ & $3 d$ & \\
\hline $2 \uparrow 50$ & $M$ & ) & \\
\hline 2830 & $M$ & $S$ & \\
\hline 1720 & w & $c=0$ & \\
\hline 1340 & $\omega$ & C It defomecion? & \\
\hline & & & \\
\hline & & & \\
\hline & & & \\
\hline & & & \\
\hline & & & \\
\hline
\end{tabular}


SAMPLE: RUN 7 - SAA - FILTER

Major Categories

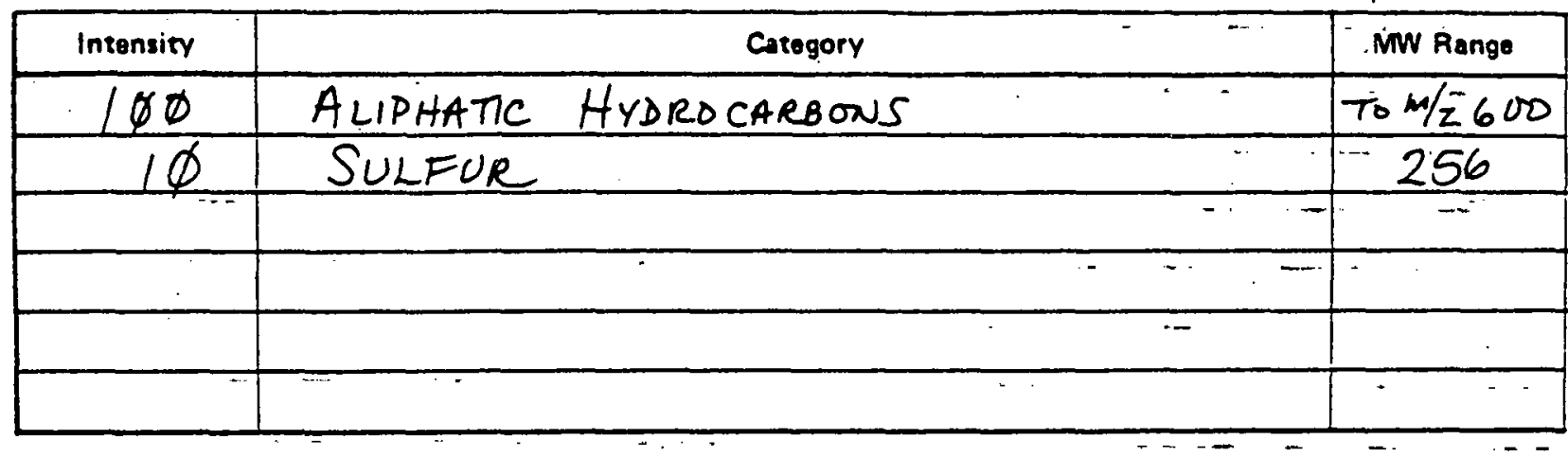

Sub-Categories, Specific Compounds

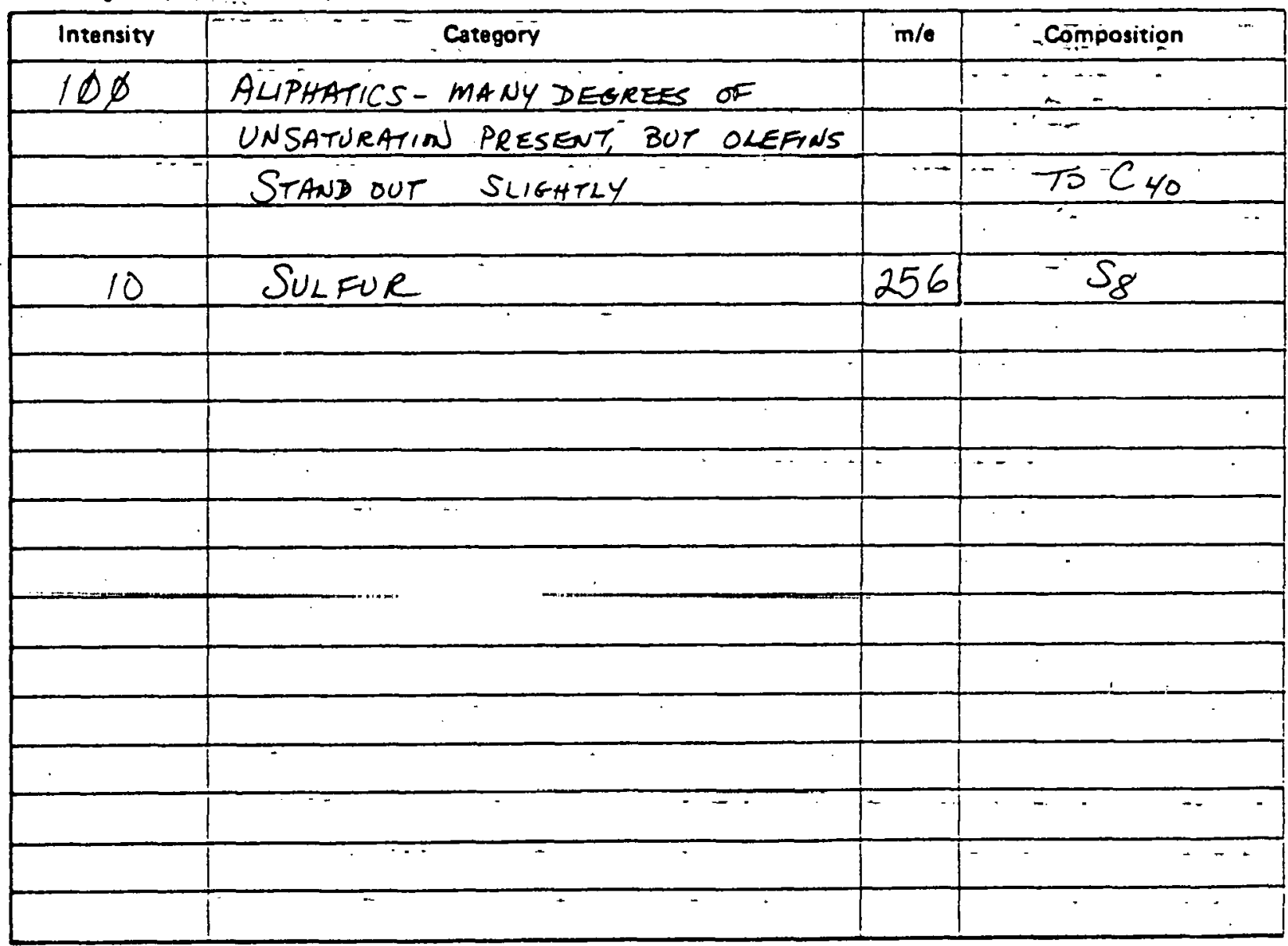

Orher 


\section{LRMS REPORT}

SAMPLE: _ RUN 7 - SAA - SORBENT

Major Categories

\begin{tabular}{|c|c|c|}
\hline Intensity & Category & MW Range \\
\hline 100 & ALIPHATIC AYdrocarbons & 70450 \\
\hline 10 & FUSE ALTEKNATE, NON ALTEKNATE HADRUCAREBOUS & $\angle 216$ \\
\hline 18 & AROMATPC HYDROCARBOUS & $75 \phi \varnothing$ \\
\hline 10 & SULFUR & 256 \\
\hline & & \\
\hline & & \\
\hline
\end{tabular}

Subrealèyuriès, 3ptclflic conpounds

\begin{tabular}{|c|c|c|c|}
\hline Intensity & Cotegory & $\mathrm{m} / \mathrm{o}$ & Composition \\
\hline 10 & NAPHPRALENEL ANS ALKYL NAPHTHARENS & $128-184$ & $C_{0} / x-C_{14} H_{16}$ \\
\hline 10 & ALKYL BIPHENYLS & $154-224$ & $C_{12} H_{10}-C_{12} H_{2 O}$ \\
\hline $1 \phi$ & 3 RING PAH ANTHRACENE PHENANTHRESE) & 178 & $\mathrm{C}_{14} \mathrm{H}_{10}$ \\
\hline $1 \varnothing$ & ALKUL 3 RING PAH & $192-296$ & $\mathrm{C}_{15} \mathrm{H}_{12}-\mathrm{C}_{16} \mathrm{H}_{14}$ \\
\hline 10 & SULFUR & 256 & $S_{8}$ \\
\hline & & & \\
\hline & & & \\
\hline & & & \\
\hline & & & \\
\hline & & & \\
\hline & & & \\
\hline & & & \\
\hline & & & \\
\hline & & & \\
\hline & & & \\
\hline & & & \\
\hline & & & \\
\hline & & & \\
\hline
\end{tabular}

\section{Orhar}

IQD ALIPHATICS ARE COMPLEY, BUT OLEFINS AND LONG CHAIN ALCYL BEUzEUES ARE Prominent. 


\section{LRMS REPORT}

SAMPLE: RUN 7 - SAA - SORBENT - FRACTION I

\section{Major Categories}

\begin{tabular}{|c|c|c|}
\hline Intensity & Category & MW Range \\
\hline $1 \phi \varnothing$ & ALIPAATIC HYDROCARBOIS & $>500$ \\
\hline $1 \varnothing$ & SULFUR & 256 \\
\hline & & \\
\hline & & \\
\hline & & \\
\hline & & \\
\hline
\end{tabular}

Sub-Categories, Specific Compounds

\begin{tabular}{|c|c|c|c|}
\hline Intensity & Category & $\mathrm{m} / \mathrm{e}$ & Composition \\
\hline $1 \phi \phi$ & ALIPHATIC HYDROCARBOWLS & $210-484$ & $C_{20}$ то $C_{35}$ \\
\hline 10 & SULFUR & 256 & $\mathrm{~S}_{8}$ \\
\hline & & - & \\
\hline & . & & \\
\hline & & & \\
\hline & & & \\
\hline & & & \\
\hline & & & \\
\hline & & & \\
\hline & & & \\
\hline & & & \\
\hline & & & \\
\hline & & & \\
\hline & 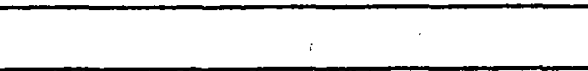 & & \\
\hline & & & \\
\hline & & & \\
\hline & & & \\
\hline & & & \\
\hline
\end{tabular}

Other 


\section{LRMS REPORT}

SAMPLE: RUN 7 - SAA - SORBENT - FRACTIONS 2-4

Major Categories

\begin{tabular}{|c|c|c|}
\hline Intensity & \multicolumn{1}{|c|}{ Category } & MW Range \\
\hline $1 \phi \phi$ & ALIPHATIC HYDROCARBOUS & - \\
\hline $1 \phi$ & FUSED ALTERNATE, NON ALTERUATE HYDROCARSONS & 2216 \\
\hline & & \\
\hline & & \\
\hline & & \\
\hline & & \\
\hline
\end{tabular}

Sub-Categories, Specific Compounds

\begin{tabular}{|c|c|c|c|}
\hline Intensity & Category & $\overline{m / e}$ & Composition \\
\hline 10 & NARHTHALENE AND ALKCYL XAAHTHLENES & $128-15$ & $\mathrm{C}_{10} \mathrm{H}_{8}-\mathrm{C}_{12} \mathrm{H}_{12}$ \\
\hline 10 & 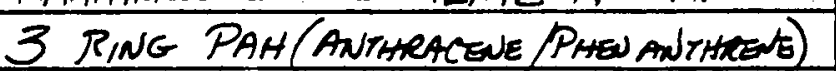 & 178 & $\mathrm{C}_{14} \mathrm{~A}_{10}$ \\
\hline$L$ & MENTHL 3 RING PAH & 192 & $\mathrm{C}_{15} \mathrm{H}_{12}$ \\
\hline 1 & I RING PAH (FL UORANTHaE BYRENE) & 202 & $C_{16} A_{10}$ \\
\hline & & & \\
\hline & & & \\
\hline & & & \\
\hline & & & \\
\hline & & & \\
\hline & & & \\
\hline & & & \\
\hline & & & \\
\hline & & & \\
\hline & & & \\
\hline & & & \\
\hline & 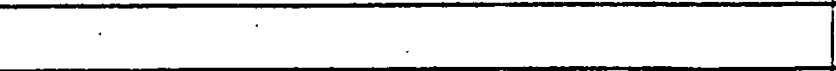 & & \\
\hline & & & \\
\hline & & & \\
\hline
\end{tabular}

Other

$1 \% \varnothing$ ALIPHATCS SHOW mavor $\mathrm{C}_{8} \mathrm{H}_{17}{ }^{+} \mathrm{lON}$ 


\section{LRMS REPORT}

SAMPLE: RUN 7 - SAA - SORBENT - FRACTIONS 5-7

\section{Major Categories}

\begin{tabular}{|c|c|c|}
\hline Intensity & Category & MW Range \\
\hline $1 \phi \varnothing$ & ALIPHATK COMPOUNDS * & Nor DEJTIPABLE \\
\hline $1 \phi \phi$ & CARBOXYLIC ACIDS & $122-20 \phi$ \\
\hline 10 & HeTEROCYCLIC NITRdGEN COMPOUNDS & 143 \\
\hline $1 \varnothing$ & UNCLASSIFIED & $150-3 \phi \phi$ \\
\hline & & \\
\hline
\end{tabular}

Sub-Categories, Specific Compounds

\begin{tabular}{|c|c|c|c|}
\hline Intensity & Category & $\mathrm{m} / \mathrm{e}$ & Composition \\
\hline $1 \phi \phi$ & BENZOC ACD & 122 & $\mathrm{CrH}_{6} \mathrm{O}_{2}$ \\
\hline 10 & METHYL QUINOLINE & 143 & $\mathrm{C}_{10} \mathrm{Hg} \mathrm{N}$ \\
\hline 10 & DODECANOIC ACID & $2 \phi \phi$ & $\mathrm{C}_{12}+\mathrm{H}_{24} \mathrm{O}_{2}$ \\
\hline & & & \\
\hline & & & \\
\hline & & & \\
\hline & & & \\
\hline & & & \\
\hline & & & \\
\hline & & & \\
\hline & & & \\
\hline & & & \\
\hline & & & \\
\hline & & & \\
\hline & & & \\
\hline & & & \\
\hline & & & \\
\hline & & & \\
\hline
\end{tabular}

Other

* Aliphatic Compounds: The Speetra Shan only the $C_{3}$ to $\sim G_{10}$ portion of the

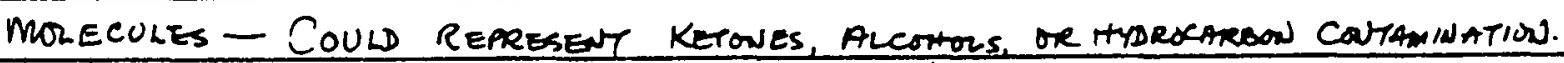


LRMS REPORT

SAMPLE:

RUN 7 - SAA - CONDENSATE

Major Categories

\begin{tabular}{|l|l|c|}
\hline Intensity & \multicolumn{1}{|c|}{ Catogory } & MW Range \\
\hline 100 & ESTERS & 390 \\
\hline 10 & UNCLASSIFIED & $104-162$ \\
\hline 0.5 & KETONES & 147 \\
\hline 0.5 & HETEROCYCLC NITROGEN COMPOUNDS & 147 \\
\hline & & \\
\hline & & \\
\hline
\end{tabular}

Süb-Categories, Snecific Compounds

\begin{tabular}{|c|c|c|c|}
\hline intensitv & Catepory & $\mathrm{m} / \mathrm{s}$ & rompasitinn \\
\hline 100 & PHTHALATE & 390 & $\mathrm{C}_{24} \mathrm{H}_{38} \mathrm{O} 4$ \\
\hline 1 & ISOINDOZE DIONE & 147 & $\mathrm{C}_{8} \mathrm{H}_{5} \mathrm{NO}_{2}$ \\
\hline & & & \\
\hline & & & \\
\hline & & & \\
\hline & & & \\
\hline & & & \\
\hline & & & \\
\hline & & & \\
\hline & & & \\
\hline & & & \\
\hline$\because$ & & & \\
\hline 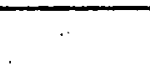 & & & \\
\hline & & & \\
\hline & & & \\
\hline & & & \\
\hline & & & \\
\hline & & & \\
\hline
\end{tabular}

Other

10: TOTAL) UNDENTIFIEd AROMATIC MATERIAL, mW 104 To 162 
IR REPORT

SAMPLE:

\begin{tabular}{|c|c|c|}
\hline $\begin{array}{l}\text { Wave Number } \\
\left(\mathrm{cm}^{-1}\right)\end{array}$ & Intemsity & Assignment \\
\hline 2970 & $M$ & 1 \\
\hline 2925 & $\omega$ & I aliatic CH-stetch \\
\hline 2855 & $\omega$ & 2 \\
\hline 1260 & $s$ & + \\
\hline 1090 & $s$ & ilopase \\
\hline 1025 & $s$ & \\
\hline 800 & $s$ & 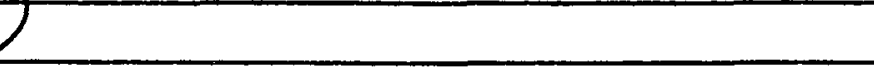 \\
\hline & & \\
\hline & & \\
\hline & & \\
\hline & & \\
\hline & & \\
\hline
\end{tabular}

IR REPORT

SAMPLE: SORBENT BLANK

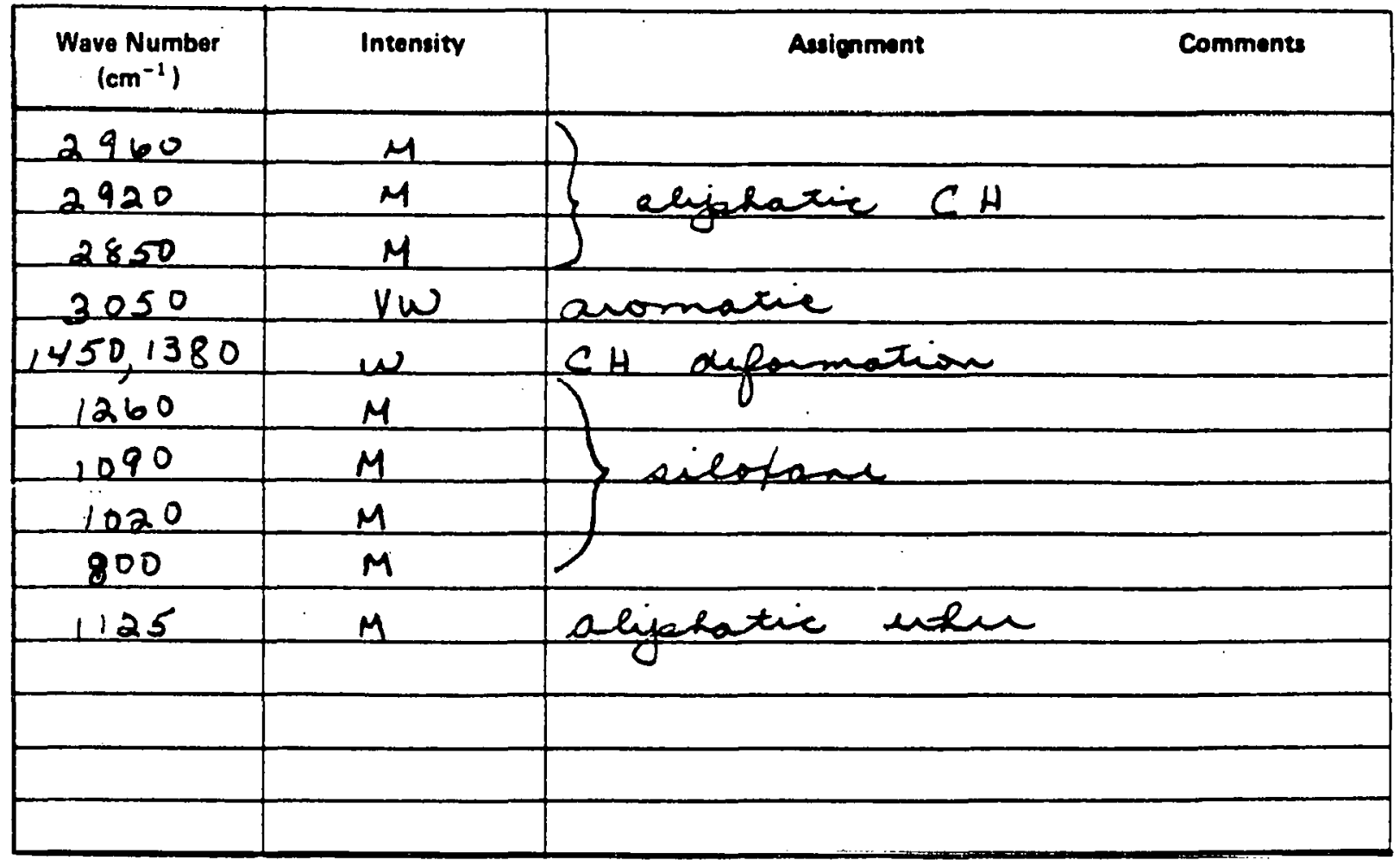




\begin{tabular}{|c|c|c|}
\hline $\begin{array}{c}\text { Wave Number } \\
\left(\mathrm{cm}^{-1}\right)\end{array}$ & Intenaity & Awsignment \\
\hline 2955 & $\omega$ & ) \\
\hline 2920 & $S$ & If shisazie CH etutes \\
\hline 2850 & $M$ & 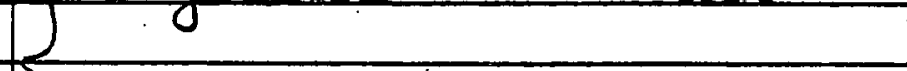 \\
\hline 1450 & $\omega$ & 1) $C H$ defumation \\
\hline 1380 & $\omega$ & 15 \\
\hline & & \\
\hline & & \\
\hline & & \\
\hline Ving & weak & the \\
\hline$\sigma$ & f & \\
\hline & & \\
\hline & & \\
\hline
\end{tabular}

IR REPORT

SAMPLE: SORBENT BLANK - FRACTIONSS 2-4

\begin{tabular}{|c|c|c|c|}
\hline $\begin{array}{l}\text { Wave Number } \\
\left(\mathrm{cm}^{-1}\right)\end{array}$ & Intenaity & Asolonmant & Comments \\
\hline & $\omega$ & & \\
\hline 2920 & $\omega$ & & $\dot{v}$ \\
\hline 2851 & $\omega$ & & \\
\hline 1120 & $\omega$ & & \\
\hline$x+2$ & & & \\
\hline \multicolumn{4}{|l|}{ ' } \\
\hline & & & . \\
\hline & & & \\
\hline & & & \\
\hline & & & \\
\hline & & & \\
\hline & & & \\
\hline
\end{tabular}




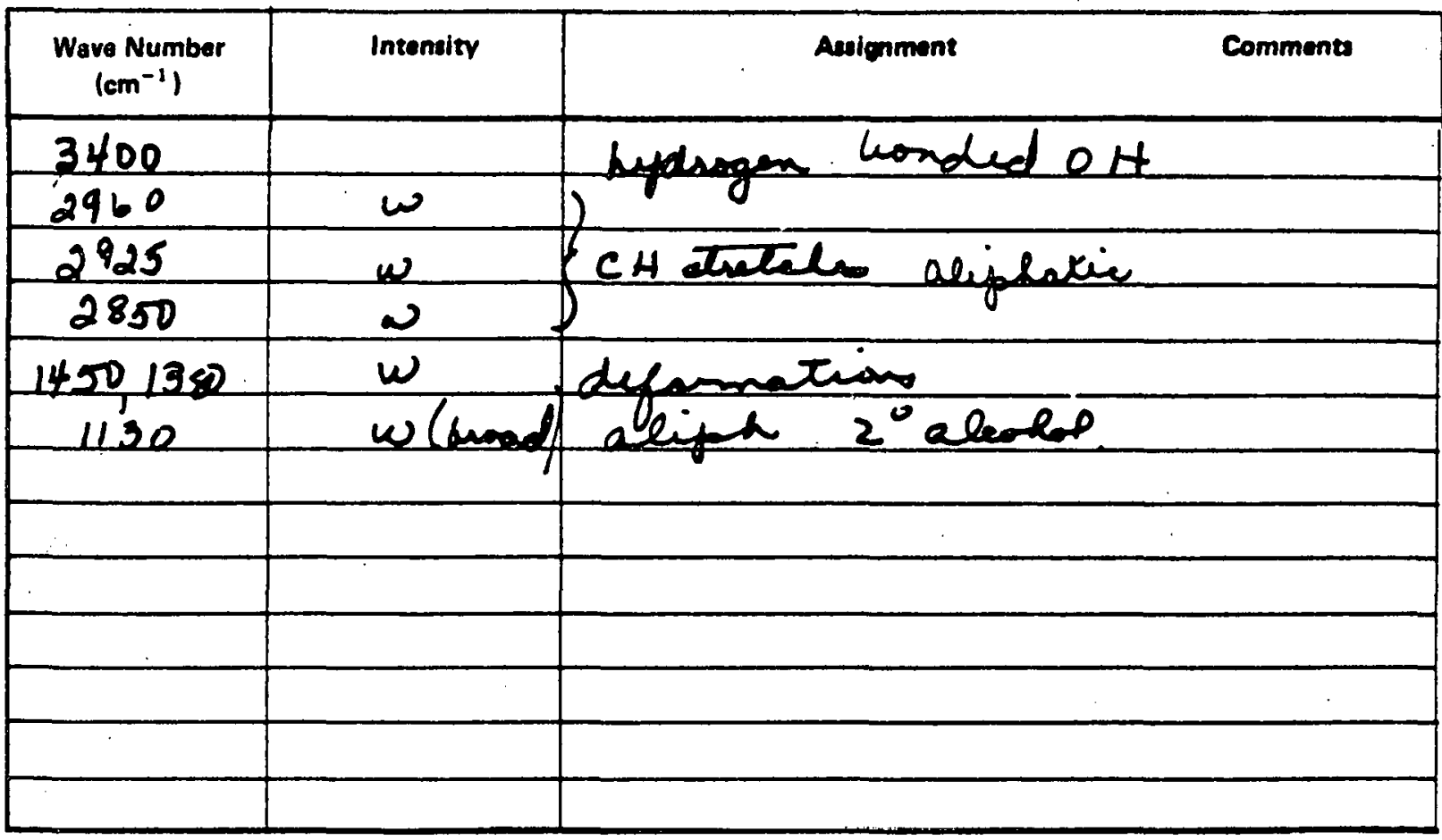

IR REPORT

SAMPLE: \ CONDENSATE BLANK

\begin{tabular}{|c|c|c|}
\hline $\begin{array}{c}\text { Wave Number } \\
\left(\mathrm{cm}^{-1}\right)\end{array}$ & Intemsity & Aesignmone \\
\hline 3360 & $\omega$ & Lithe NHai $O H$ \\
\hline 2960,2920 & M & Des: \\
\hline 2850 & $M$ & \\
\hline 1735 & $s$ & $c=0$-estu? prosibly propiorate \\
\hline 1270 & $M$ & \\
\hline Ltis ale & apessiale & that tois repeacent DOP which \\
\hline was not & Wully sul & tacted out. \\
\hline & 00 & \\
\hline & & \\
\hline & & \\
\hline & & \\
\hline & & \\
\hline & & \\
\hline
\end{tabular}


IR REPORT

SAMPLE: SOLVENT BLANK

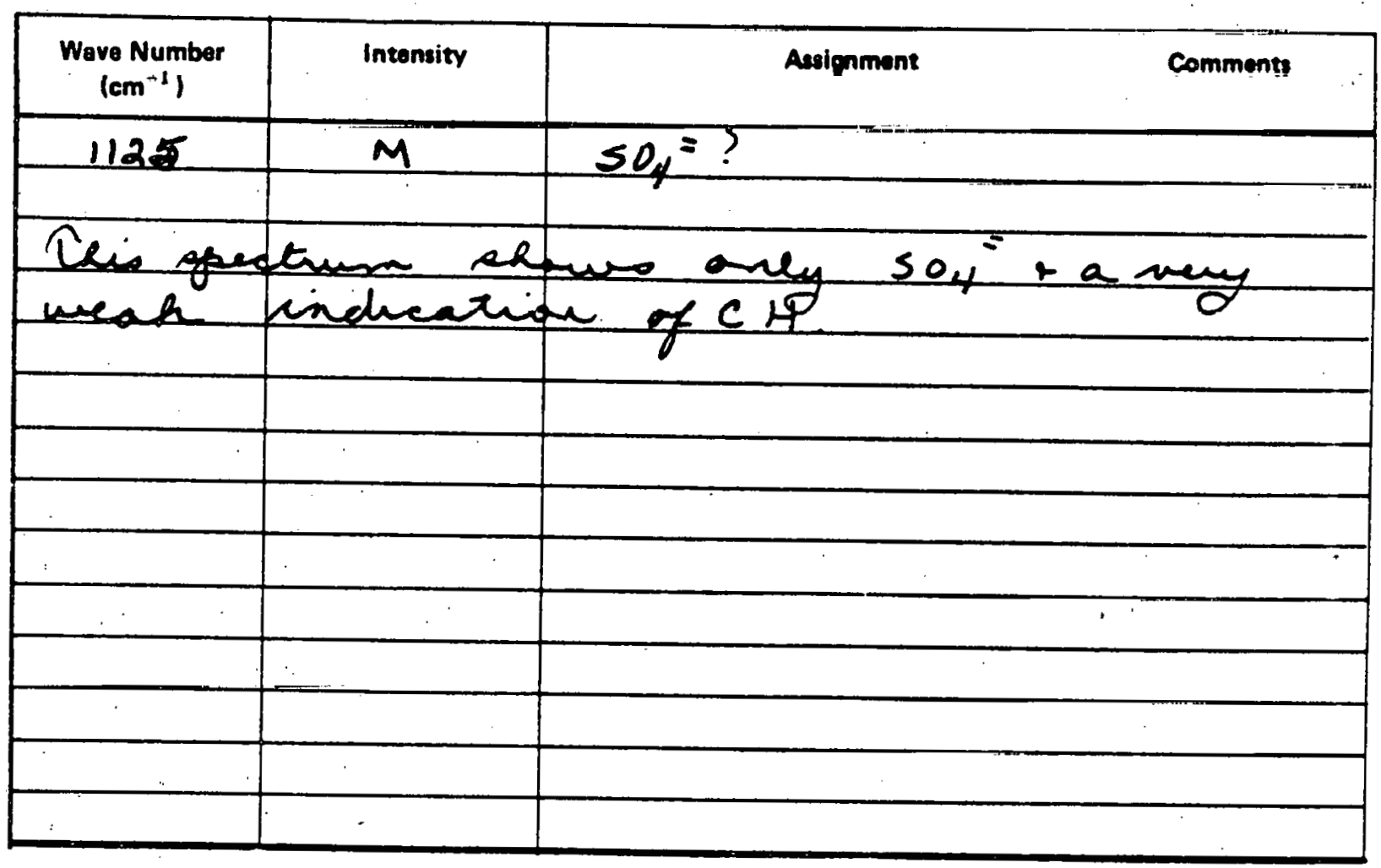


LRMS REPORT

SAMPLE: BLANK FILTER

Major Categories

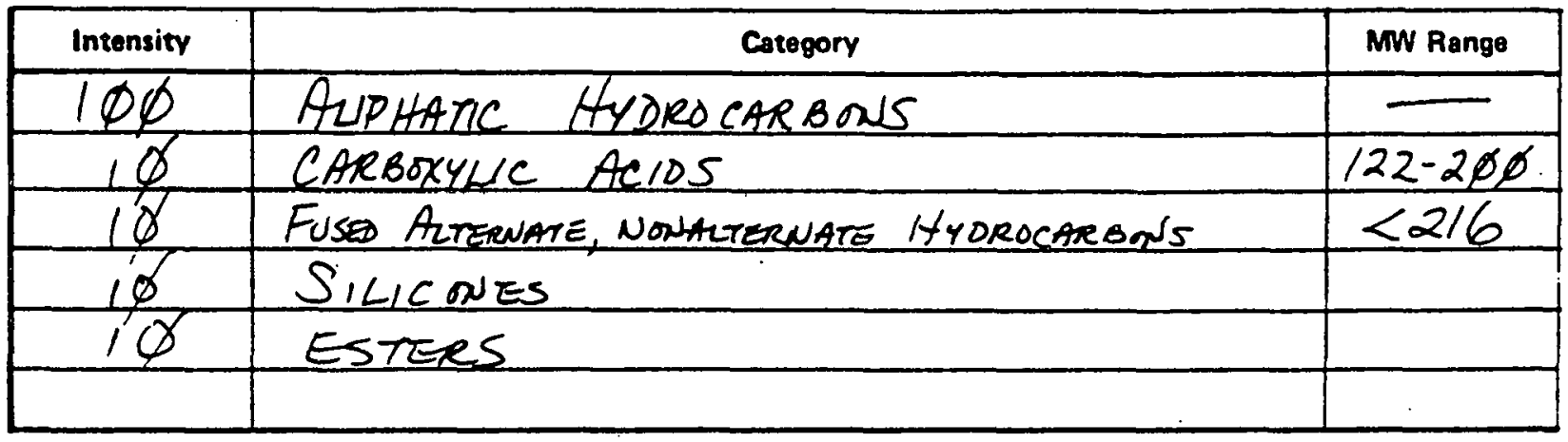

Sub-Categories, Specific Compounds

\begin{tabular}{|c|c|c|c|}
\hline Intensity & Category & $\mathrm{m} / \mathrm{e}$ & Composition \\
\hline $1 \phi$ & BEUZOIC ACID & 122 & $\mathrm{C}_{7} \mathrm{H}_{6} \mathrm{O}_{2}$ \\
\hline 10 & 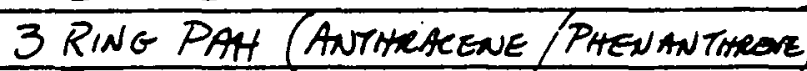 & 178 & $C_{14} H_{10}$ \\
\hline 10 & PhtThalate, DOP TYPE & $39 \varnothing$ & $\mathrm{C}_{24} \mathrm{H}_{38} \mathrm{O}_{4}$ \\
\hline $1 \phi$ & 4 RING PAH (FluRANTHENE (PYRENE) & $2 \phi_{2}$ & $C_{16} A_{10}$ \\
\hline 10 & PHENYL NAPHTHALENE & $2 \phi 4$ & $C_{16} A_{12}$ \\
\hline $1 \varnothing$ & METAYL 3 RING PAH & 192 & $\mathrm{C}_{15} \mathrm{H}_{12}$ \\
\hline $1 \varnothing$ & TEREPHENYC & $23 \phi$ & $\mathrm{C}_{18} \mathrm{H}_{14}$ \\
\hline $1 \varnothing$ & METHYL PHENYY NAPHTI+ALENE & 218 & $\mathrm{C}_{17} \mathrm{H}_{14}$ \\
\hline & & & \\
\hline & & & \\
\hline & & & \\
\hline & & & \\
\hline & & & \\
\hline & & & \\
\hline & & & \\
\hline & & & \\
\hline & & & \\
\hline & & & \\
\hline
\end{tabular}

Other
10
S/LIC ONES
To
$m / z>50 \phi$ 
SAMPLE: BLANK SORBENT - FRACTION 1

Major Categories

\begin{tabular}{|l|l|l|}
\hline Intensity & Category & MN Range \\
\hline $1 \varnothing \varnothing$ & ALIPHATIC HYDROCAR BONS * & \\
\hline & & \\
\hline & & \\
\hline SAMPLE HAD VERY LOW CNCENTRATION-COULD NOT & \\
\hline IDENTIFY MOLCONAR WEIGHT RANGE & \\
\hline
\end{tabular}

Sub-Categories, Specific Compounds

\begin{tabular}{|l|l|l|l|}
\hline inzensity & $\cdots$ & $\mathrm{m} / \bullet$ & Composition \\
\hline & & & \\
\hline & & & \\
\hline & & & \\
\hline & & & \\
\hline & & & \\
\hline & & & \\
\hline & & & \\
\hline & & & \\
\hline & & & \\
\hline & & & \\
\hline & & & \\
\hline & & & \\
\hline & & & \\
\hline & & & \\
\hline & & & \\
\hline & & & \\
\hline
\end{tabular}

\section{Other}


- SAMPLE: BLANK SORBENT - FRACTIONS 2-4

Major Categories

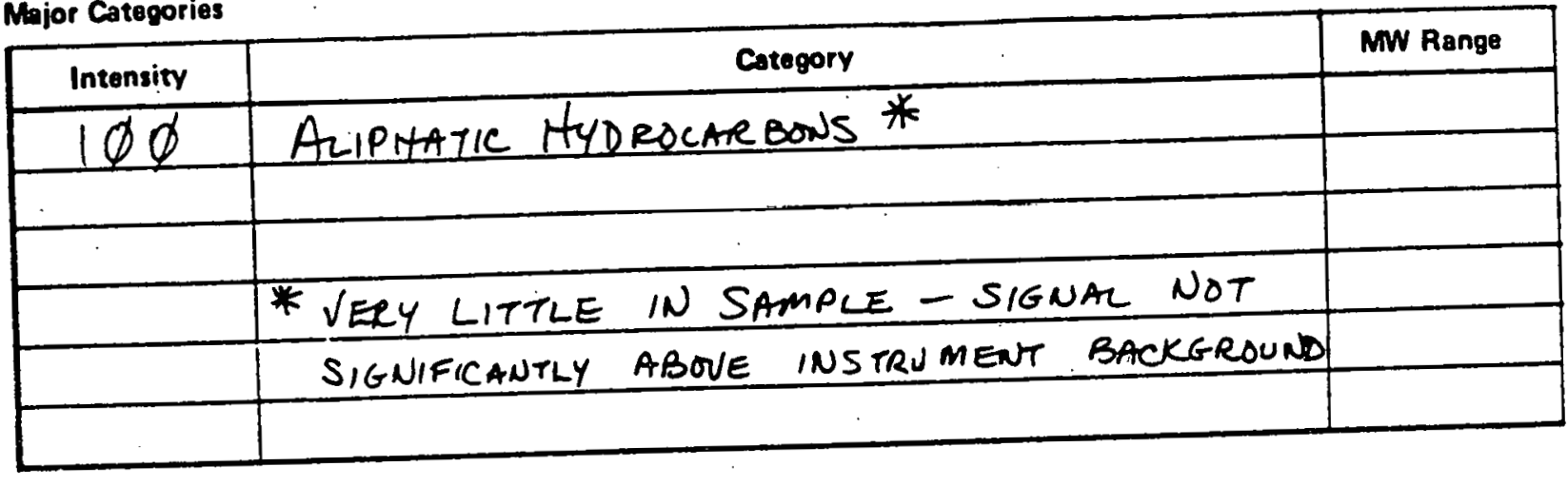

Sub-Categories, Specific Compounds

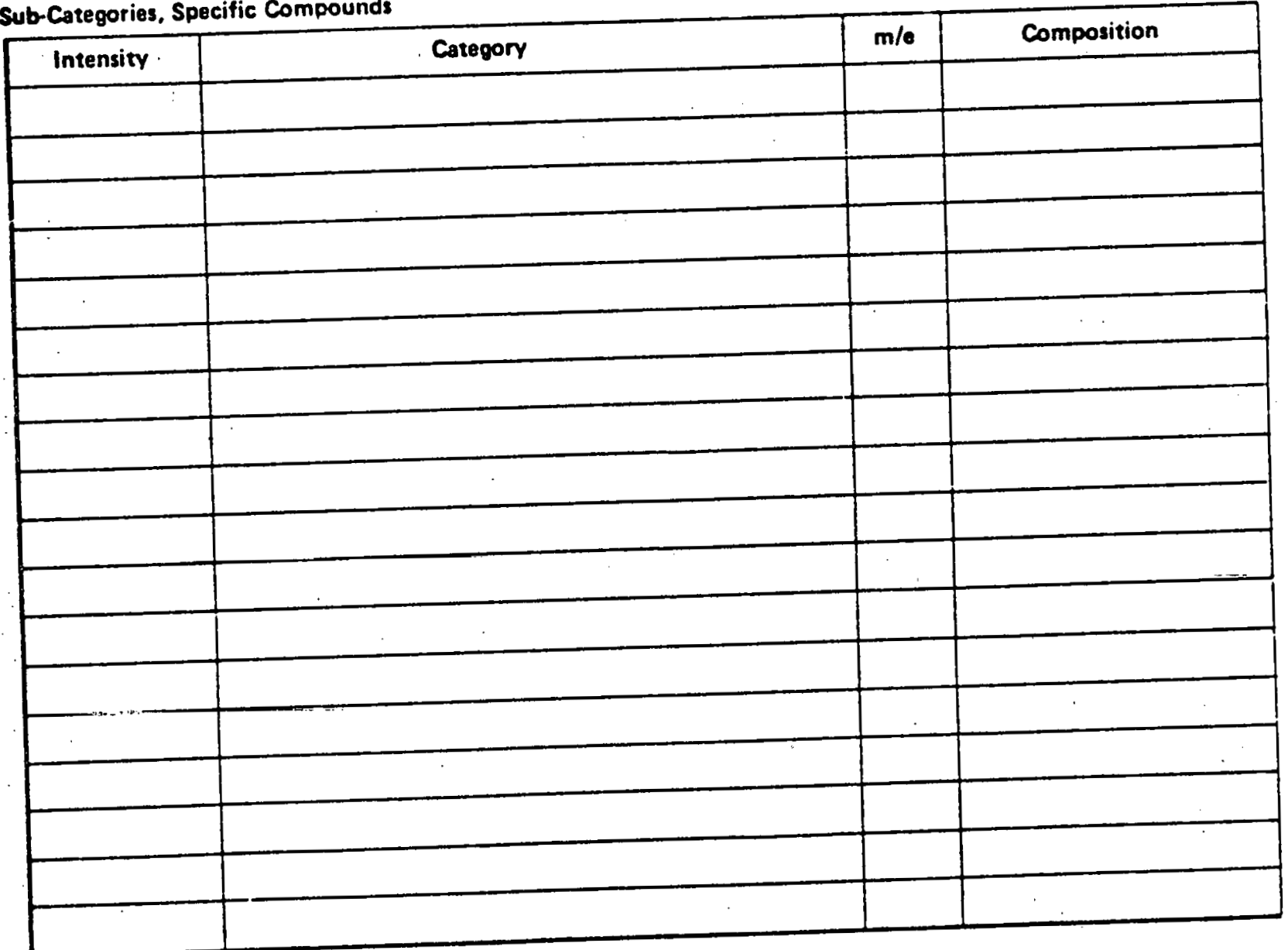

\section{Other}


LRMS REPORT

SAMPLE:_ 3LANK SORBENT - FRACTIONS 5-7

Major Categories

\begin{tabular}{|c|c|c|}
\hline Intensity & Category & MW Range \\
\hline $1 \phi \phi$ & ALPHATIC HYDROCARBOWS *K & \\
\hline & & \\
\hline VEeY L & TTLE IN SAMPLE - SIGNAZ NOT SIGNIFCANTLY & \\
\hline ABOVE & INSTRUMENT BACK GROUND. & \\
\hline & & " \\
\hline
\end{tabular}

Sub-Categories, Specific Compounds

\begin{tabular}{|c|c|c|c|}
\hline Intensity & Category & $\mathrm{m} / \mathrm{e}$ & Composition \\
\hline & & & \\
\hline & & & \\
\hline & & & \\
\hline & & & \\
\hline & & & \\
\hline & & & \\
\hline & & & \\
\hline & & & \\
\hline & & & \\
\hline & & & \\
\hline & & & \\
\hline & & & \\
\hline . & & & \\
\hline & & & \\
\hline & & & \\
\hline & & & \\
\hline & & & \\
\hline
\end{tabular}

Other 
LRMS REPORT

SAMPLE:

BLANK SOLVENT - CONDENSATE

Major Categories

\begin{tabular}{|l|l|c|}
\hline Intensity & Category & Mw Range \\
\hline 100 & ESTERS & 390 \\
\hline 100 & UNCLASSIFIED & $\sim 200$ \\
\hline & & \\
\hline & & \\
\hline & & \\
\hline & & \\
\hline
\end{tabular}

Sub-Categories, Specific Compounds

\begin{tabular}{|l|l|l|l|}
\hline Intensity & Category & $\mathrm{m} / \mathrm{0}$ & Composition \\
\hline 100 & PHTHALATE & 390 & $\mathrm{C}_{24} \mathrm{H}_{38} \mathrm{O}_{4}$ \\
\hline & & & \\
\hline & & & \\
\hline & & & \\
\hline & & & \\
\hline & & & \\
\hline & & & \\
\hline & & & \\
\hline & & & \\
\hline & & & \\
\hline & & & \\
\hline & & & \\
\hline & & & \\
\hline
\end{tabular}

Other

100 UNIDENTIFIABLE BENZOYL CONTAING MATERIAL, WTH MAJOR PEAKS AT $\mathrm{m} / \mathrm{z} \quad 77,105,133$ 


\section{THIS PAGE \\ WAS INTENTIONALLY \\ LEFT BLANK}


APPENDIX B

SPARK SOURCE MASS SPECTROMETRY ANALYSIS DATA 


\section{THIS PAGE WAS INTENTIONALLY LEFT BLANK}


SPARK SOURCE MASS SPECTROMETRY (SSMS) ANALYSIS DATA

TABLE OF CONTENTS

Page

Af terburner Runs

Run 2 - SSMS Report

Run 3 - SSMS Report

114

Run 4 - SSMS Report

Stack Air Addition System Runs

Run 5 - SSMS Report

Run 6 - SSMS Report

Run 7 - SSMS Report

Matrix Blanks

129

National Bureau of Standards

SRM QC 1648, Urban Particulate 


\section{THIS PAGE}

\section{WAS INTENTIONALLY \\ LEFT BLANK}




$$
\text { RUN } 2 \text { - AFB - FILTER }
$$

\begin{tabular}{|c|c|c|c|}
\hline 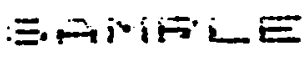 & I豆. & : & $1 \leq S=\bar{O}$ \\
\hline 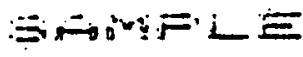 & initi. & $=$ & $\Leftrightarrow \quad \therefore \leq T$ \\
\hline
\end{tabular}

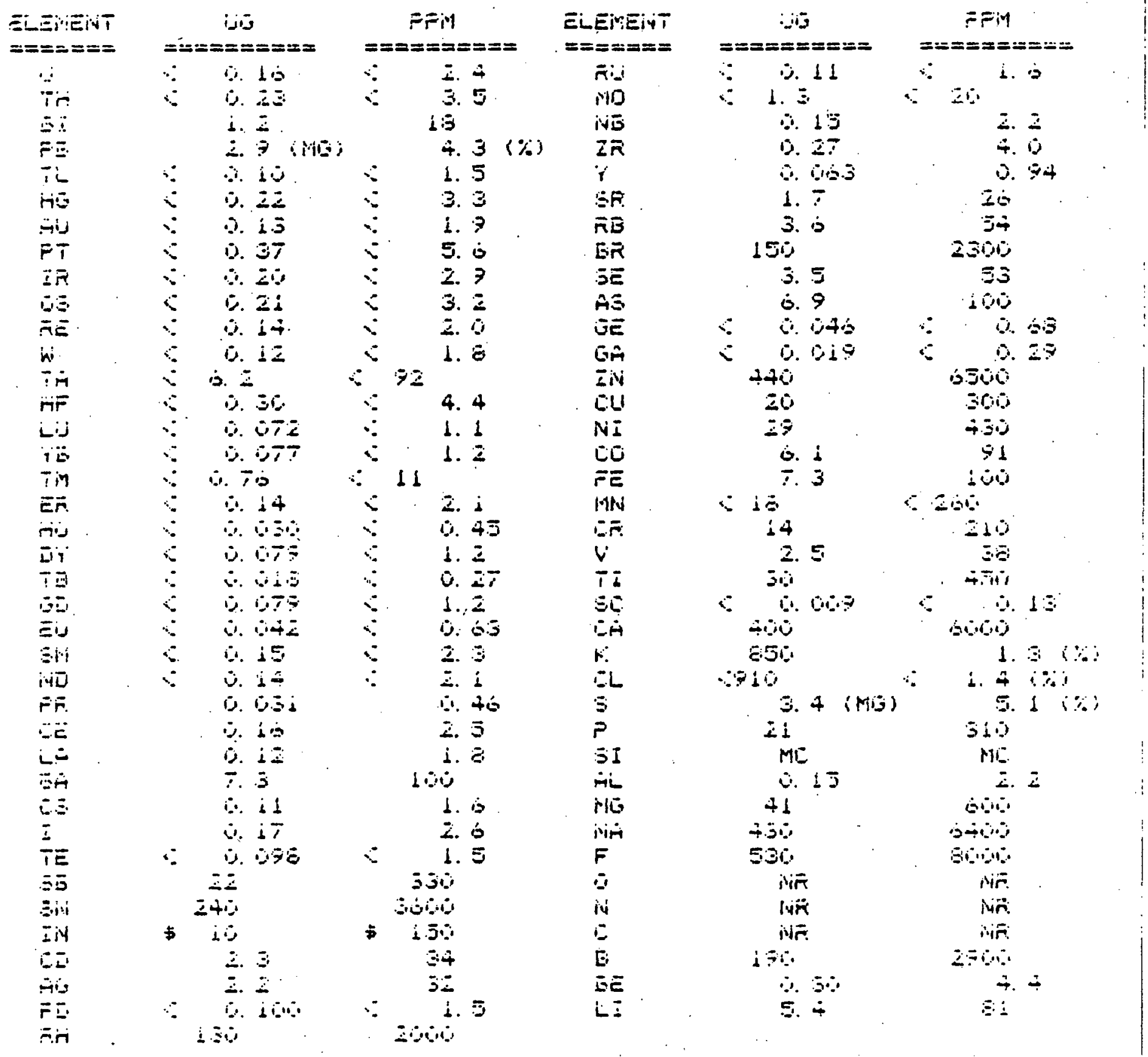


RUN 2 - AFB - SORBENT

\begin{tabular}{|c|c|c|c|}
\hline :三NMFLE & $I \pm 3$. & : & $\perp E \Delta \equiv$ \\
\hline$=$ & ind $T$. & : & ㅁ. EREA \\
\hline
\end{tabular}

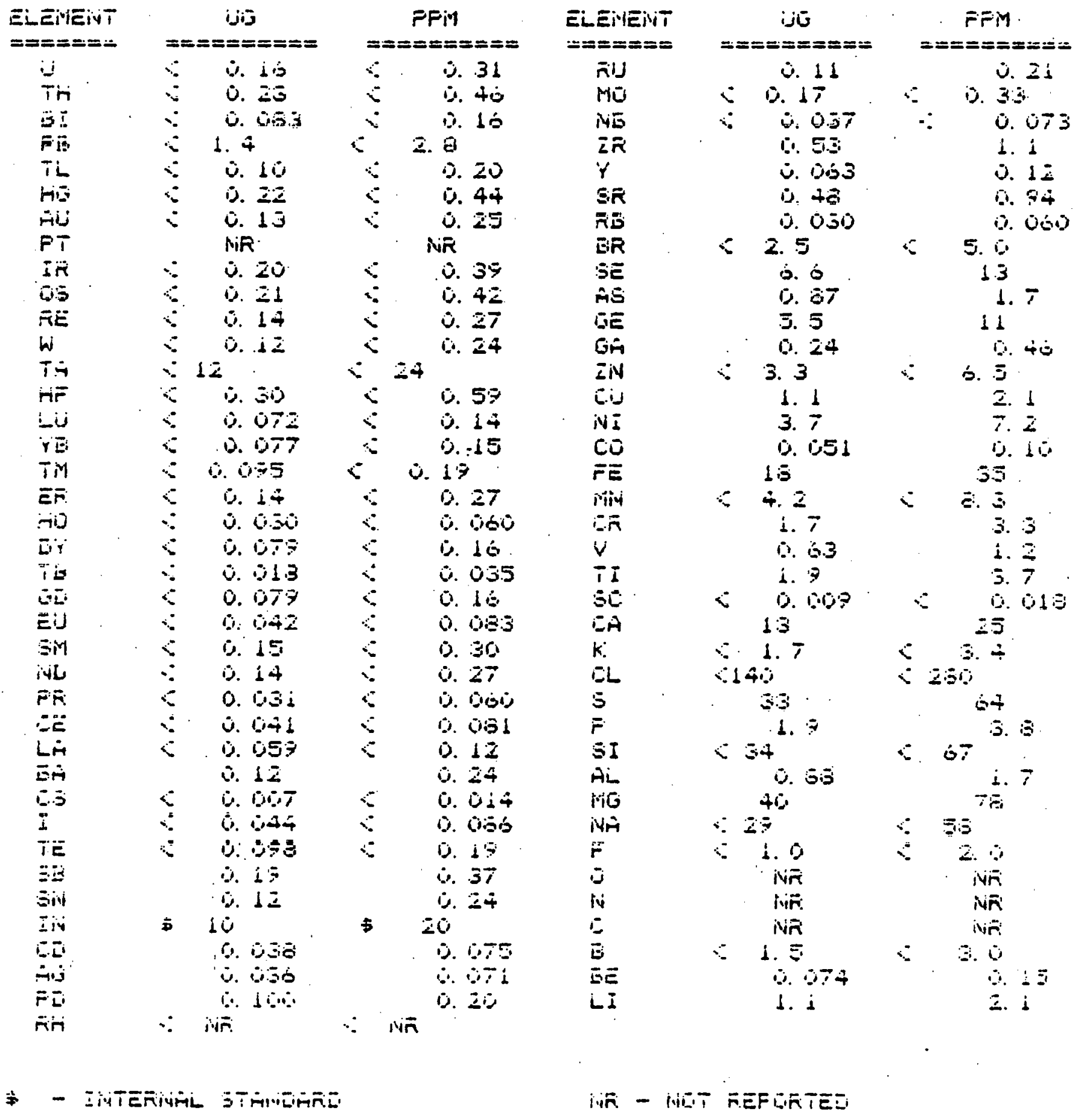




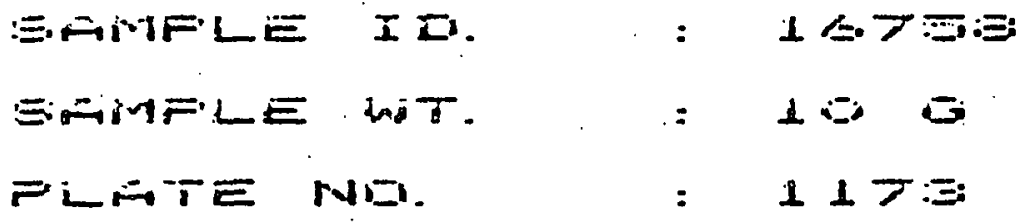

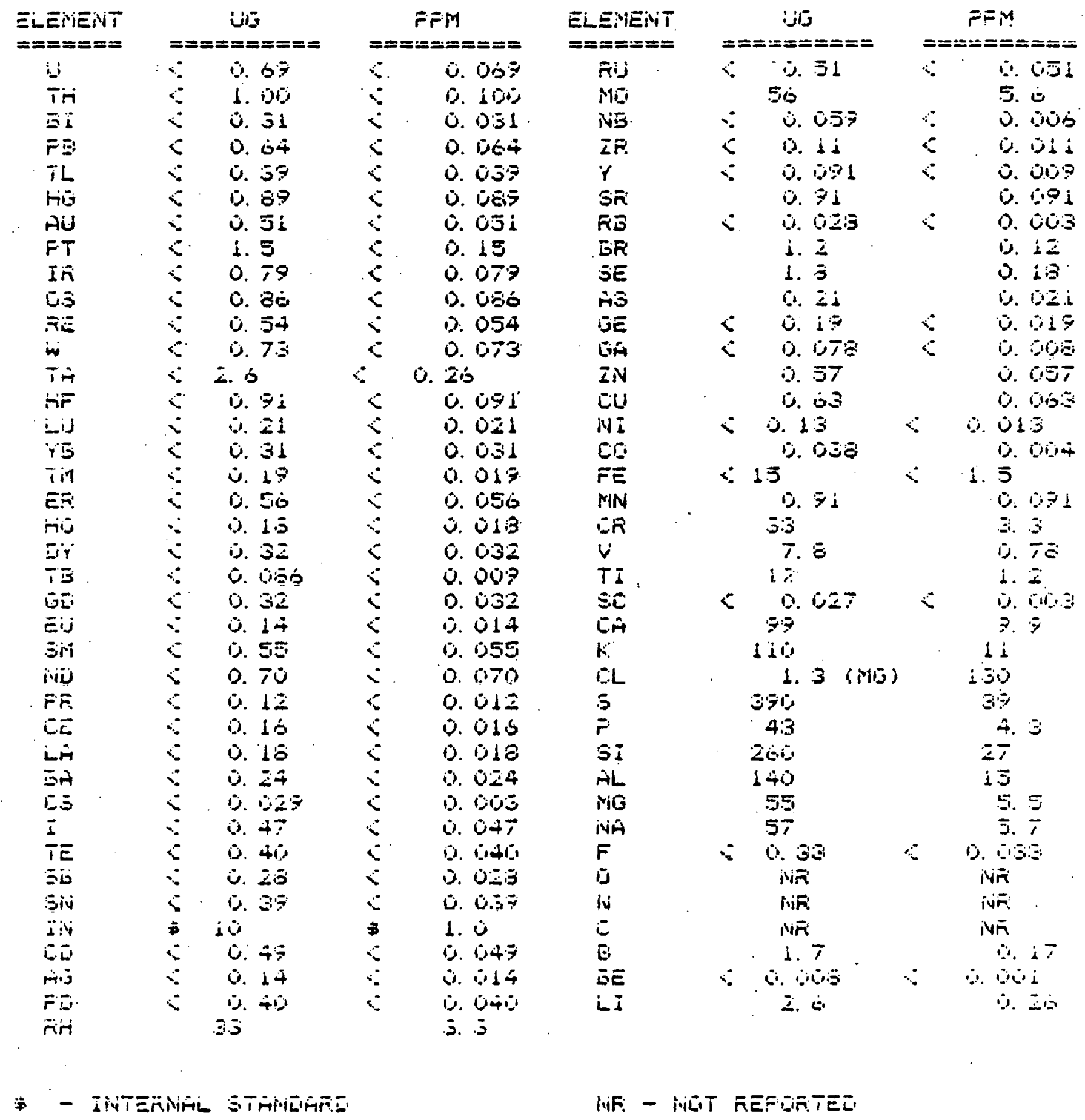


RUN 3 - AFB - FILTER

\begin{tabular}{|c|c|c|c|}
\hline 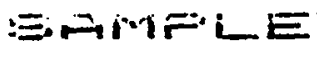 & $I$ II. & : & $1 \leq \leqslant x$ \\
\hline 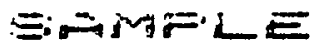 & Wit. & : & $\therefore \nabla$ \\
\hline
\end{tabular}

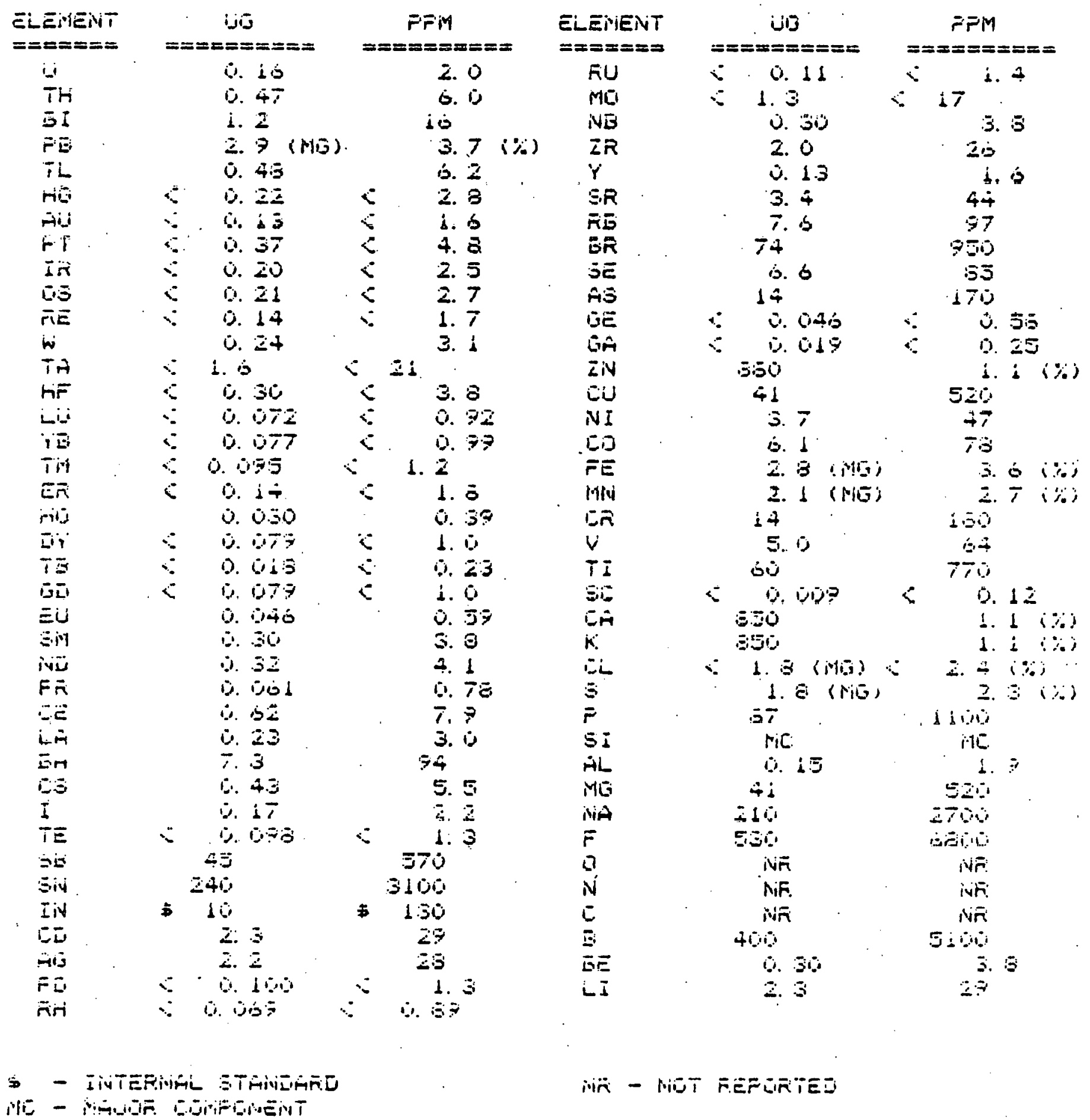


RON 3 - AFB - SORBENT

\begin{tabular}{|c|c|c|c|}
\hline$\equiv . \leadsto r \cdot 1 F \cdot L E$ & III. & : & $1 S \Delta: \equiv$ \\
\hline 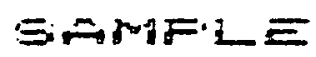 & ind $T$. & : & 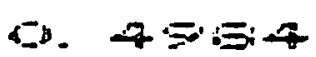 \\
\hline
\end{tabular}

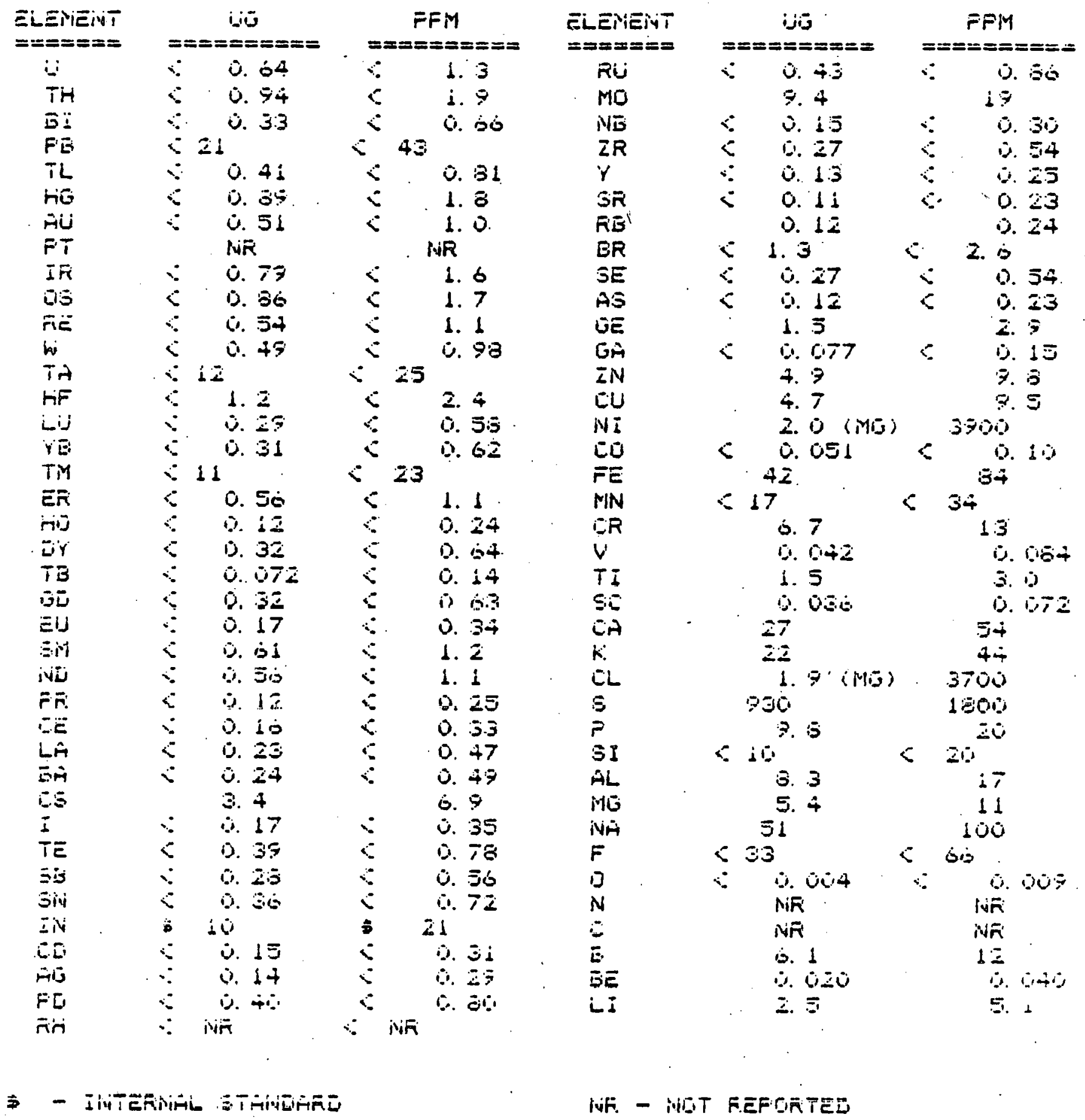


RUN 3 - AFB - CONDENSATE

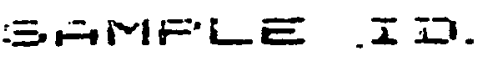

EDMFLE WT.

FL
: $1 \leftrightarrow フ \Xi$

$=19 \square$

$: \quad 117 \%$

\begin{tabular}{|c|c|}
\hline $\begin{array}{l}E L E N V \text { NiUT } \\
======\end{array}$ & $==========$ \\
\hline$i j$ & 0.24 \\
\hline Tri & i. 50 \\
\hline$\nabla I$ & 0. 1.5 \\
\hline$F$ & d. 3 \\
\hline$T L$ & 0.17 \\
\hline$H \bar{S}$ & 0. 44 \\
\hline Filj & 0.20 \\
\hline FT & i. 75 \\
\hline$I \vec{n}$ & 5.3 \\
\hline 05 & 0.43 \\
\hline $\bar{n} \bar{E}$ & 0.27 \\
\hline w & 0.37 \\
\hline IA & $\exists .1$ \\
\hline IIF & c. 45 \\
\hline نiن & o. 11 \\
\hline$Y B$ & 0.15 \\
\hline $7 \mathrm{in}$ & 6. 0.5 \\
\hline ER & $\therefore 2 E$ \\
\hline ij & 0. 01 \\
\hline Lit & D. is \\
\hline نظ T & 0. $\quad 43$ \\
\hline $5 \overline{5}$ & 0. $1 \dot{1}$ \\
\hline Eij & 0.072 \\
\hline EN & 0.20 \\
\hline ن نL & ... 55 \\
\hline F' & b. $\Delta 01$ \\
\hline $\bar{E}$ & ㅇ. ن் \\
\hline Li் & j. \\
\hline$\Xi \bar{~}$ & $\therefore 12$ \\
\hline$E \equiv$ & ㅁ. 014 \\
\hline$i$ & 1. $\bar{r}$ \\
\hline TE & 0.20 \\
\hline$\Xi i$ & $0.1 \%$ \\
\hline Siq & 3. \\
\hline$I n$ & 10 \\
\hline ED & i. 35 \\
\hline Ji & $\therefore \therefore z$ \\
\hline$F$ & ij. 20 \\
\hline $\bar{n}$ & $\therefore 0$ \\
\hline
\end{tabular}

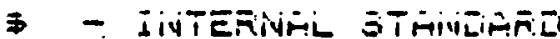

\begin{tabular}{|c|c|c|}
\hline & $\begin{array}{l}P M \\
======\end{array}$ & $\begin{array}{l}\text { E:EIrENNT } \\
=======\end{array}$ \\
\hline 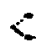 & 0. 134 & زاה \\
\hline & 0.050 & MU \\
\hline & ن. & $N B$ \\
\hline & 0.13 & $2 \pi$ \\
\hline & 0.017 & $\gamma$ \\
\hline & D. 044 & $S R$ \\
\hline & 0.026 & $\bar{F}$ B \\
\hline & $\begin{array}{l}\text { 0. } 075 \\
0.55\end{array}$ & $\begin{array}{l}\text { BR } \\
\text { SE }\end{array}$ \\
\hline & ij. 043 & $A B$ \\
\hline & 3. 027 & DE \\
\hline & 0. 1337 & EA \\
\hline & 0.71 & $I N$ \\
\hline & D. $\$ 45$ & $C:$ \\
\hline & 0.011 & NI \\
\hline & 0.015 & {$[0$} \\
\hline & 0.005 & FE \\
\hline & ง. $0=8$ & Min \\
\hline & 0. $\Delta 0 ; \%$ & Сत̄ \\
\hline & ㅁ. 010 & $v$ \\
\hline & ن. 004 & $T I$ \\
\hline & 0.010 & 30 \\
\hline & 3. 807 & $\dot{E}$ \\
\hline & 0. & in. \\
\hline & 0.055 & EL \\
\hline & 0. 400 & $\Xi$ \\
\hline & 0.503 & $P$ \\
\hline & o. bijs & $S I$ \\
\hline & ن. $01 \bar{z}$ & $\mathrm{HL}$ \\
\hline & ن. 101 & rivo \\
\hline & 0. 19 & ive \\
\hline & $\therefore 020$ & $\mathbf{F}$ \\
\hline & 0.017 & 1 \\
\hline & 0.80 & $i v$ \\
\hline & 1.0 & $\Xi$ \\
\hline & 0. & $\overline{5}$ \\
\hline & $\theta \pi^{-1}$ & $\overline{D E}$ \\
\hline & ד & LI \\
\hline
\end{tabular}

FFin

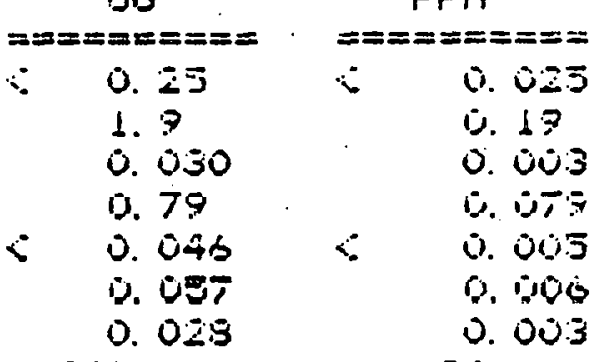

340.34

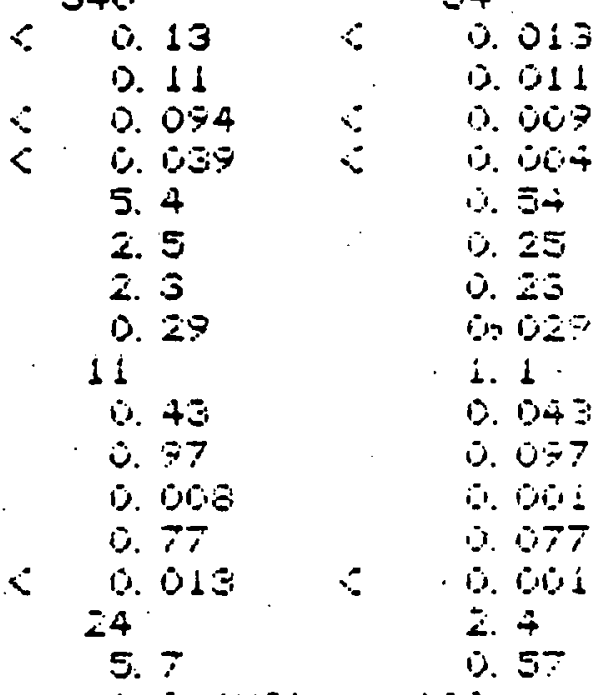

5. 7

1. 0 (Nij) 100

710

1. 0

31

i. 27

27

76

3. 4

Nin

NR

in

$\therefore 0.99000$

$\therefore \quad \therefore 604 \quad \therefore \quad 060$ io
72

ง. 10

3.1

a. 02

‥

$T: B$

b. 3

iñ̄i

ivis

औरत

1. i)

MiF - MUT FEETRETES 


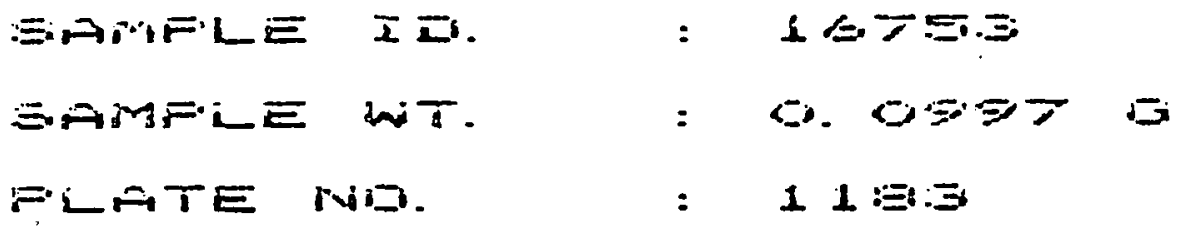

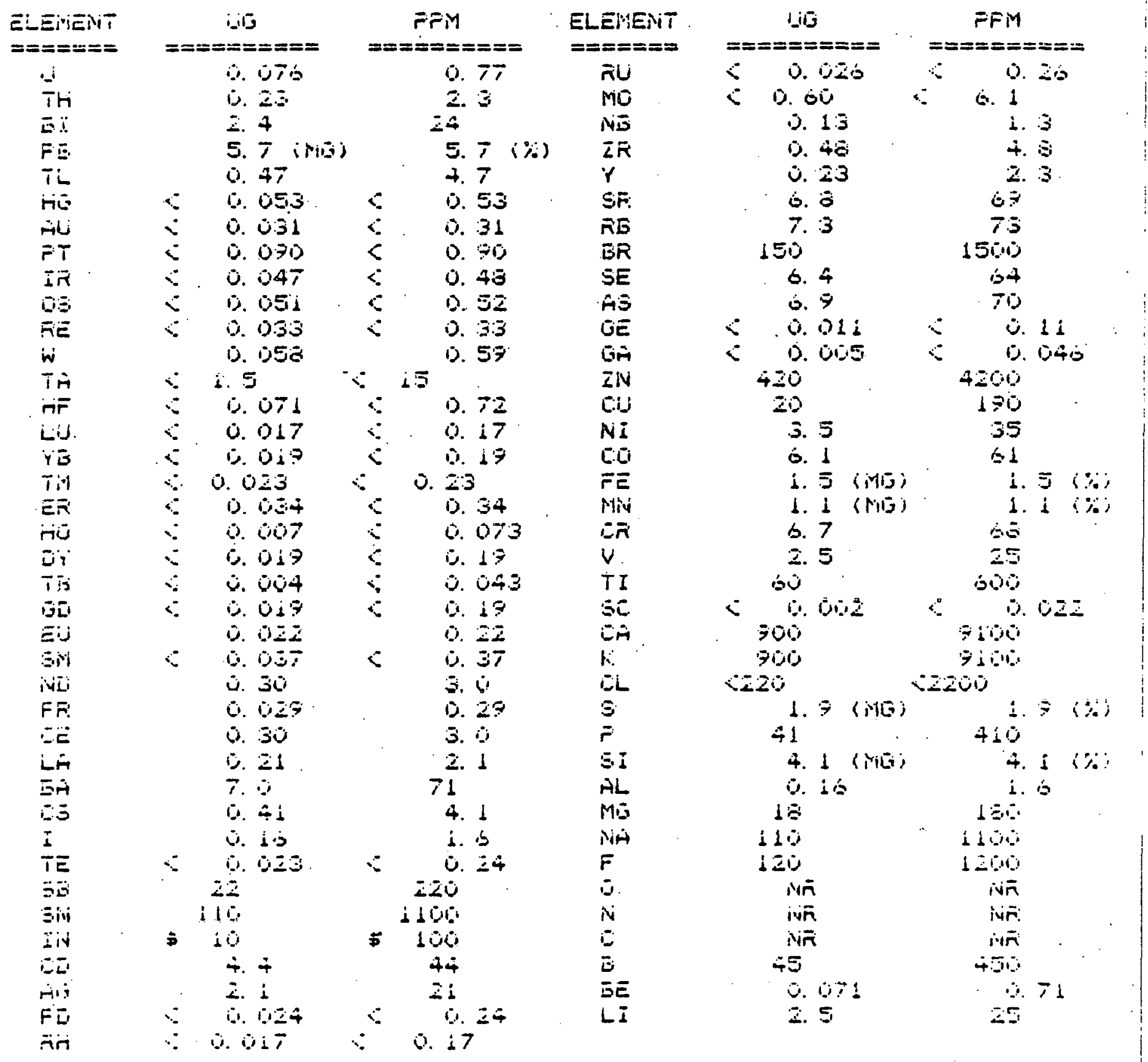




\begin{tabular}{|c|c|c|c|}
\hline$: \equiv . \sim a r \cdot \sigma=L E$ & $I \Phi$. & : & $1 \leqslant \omega: \exists 4$ \\
\hline$\equiv: \rightarrow \pi+1=i=$ & WT. & $=$ & Ex. $\div 4 \div 5$ \\
\hline
\end{tabular}

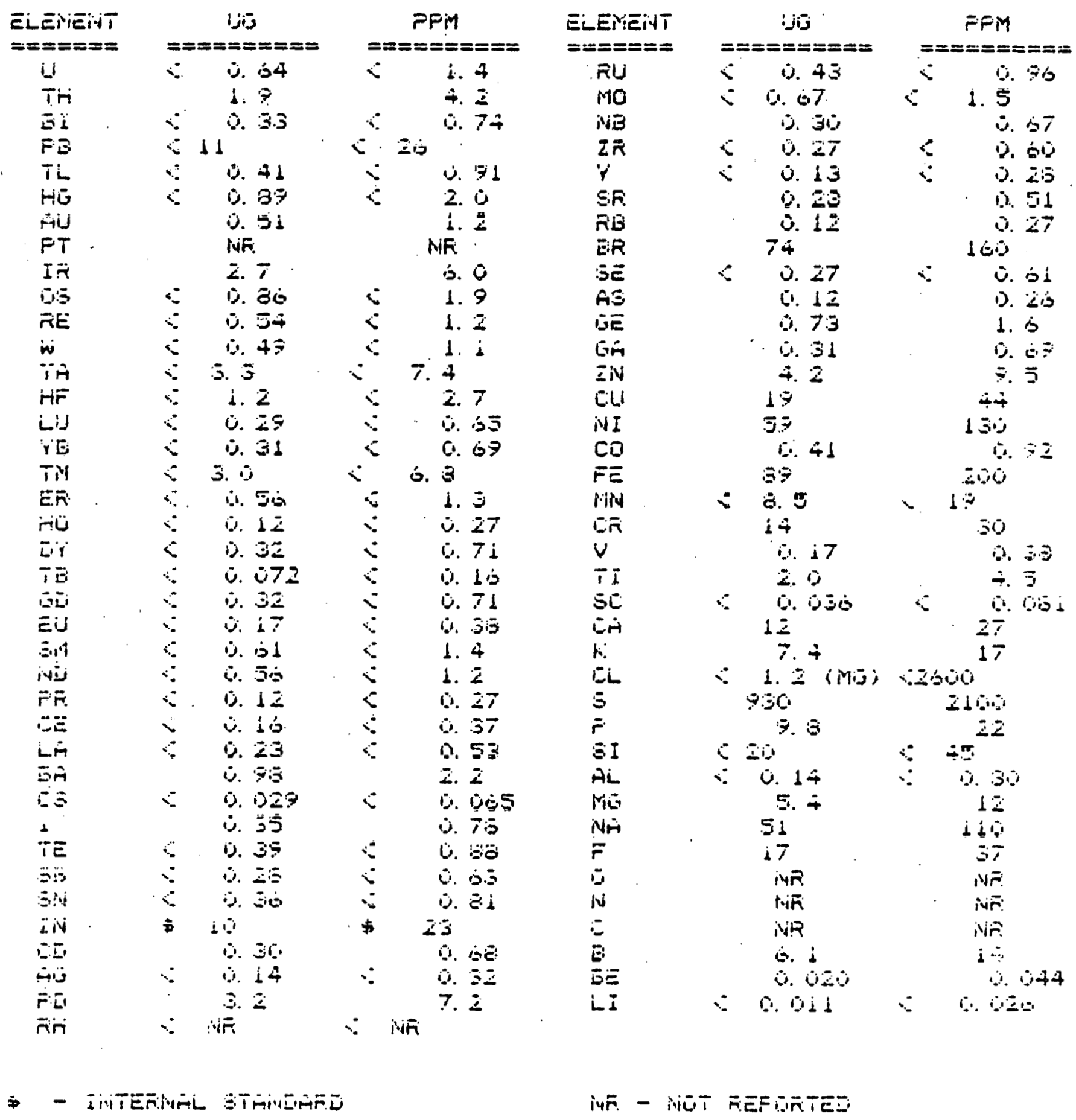




\begin{tabular}{|c|c|c|c|}
\hline 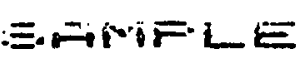 & $x=$ & $:$ & 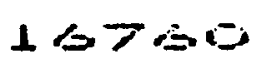 \\
\hline 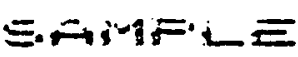 & int. & : & $1 \approx$ \\
\hline
\end{tabular}

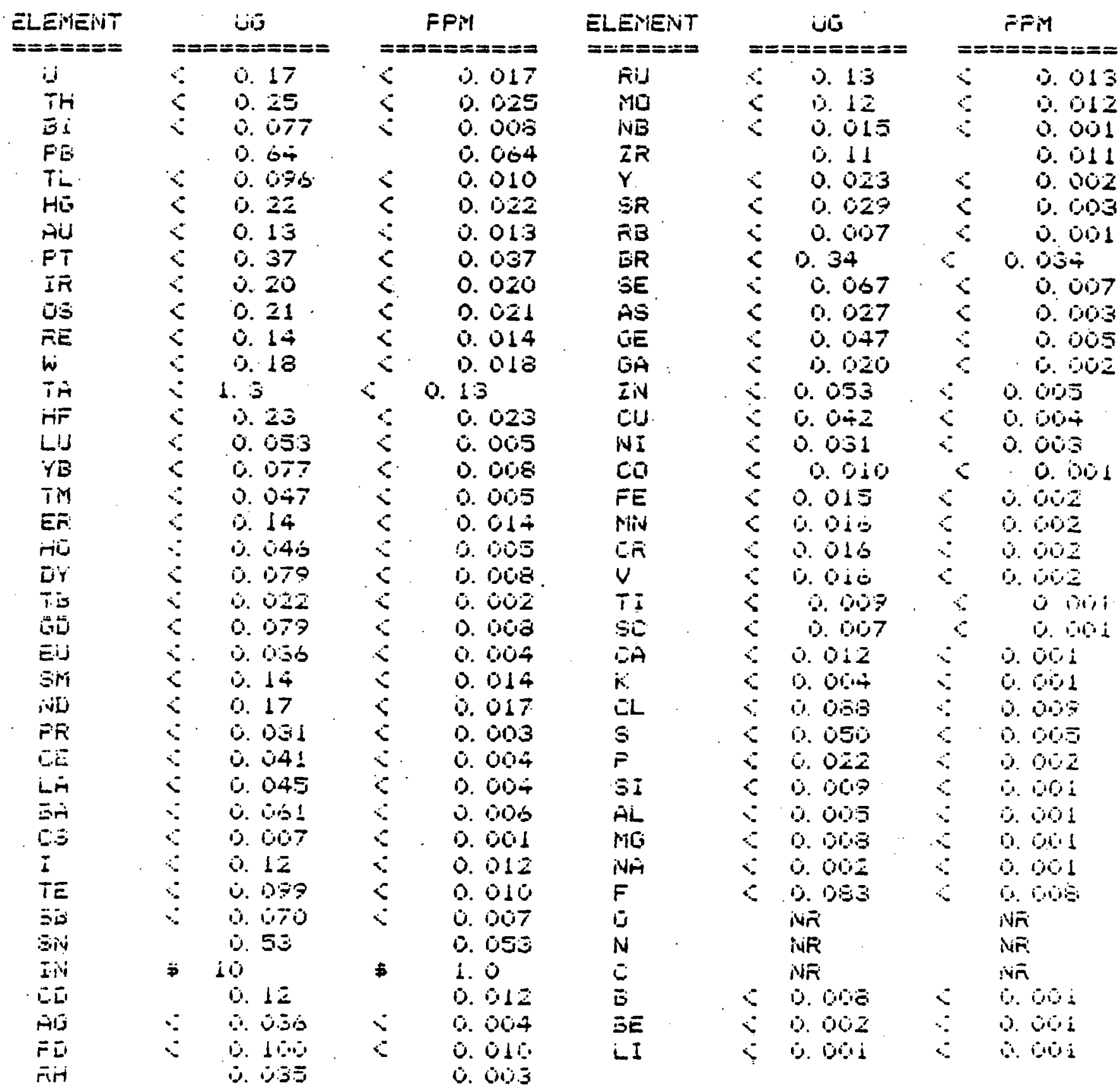




\begin{tabular}{|c|c|c|c|}
\hline 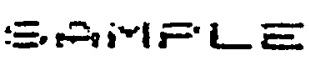 & $I=$. & $:$ & $1 \Leftrightarrow 7 \equiv 4$ \\
\hline$\dot{S}-2 x, 3 F \cdot L E$ & and $T$ & : & $\therefore \therefore \quad i=>\equiv=$ \\
\hline 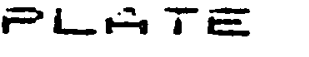 & 3 & : & $11: \equiv: 4$ \\
\hline
\end{tabular}

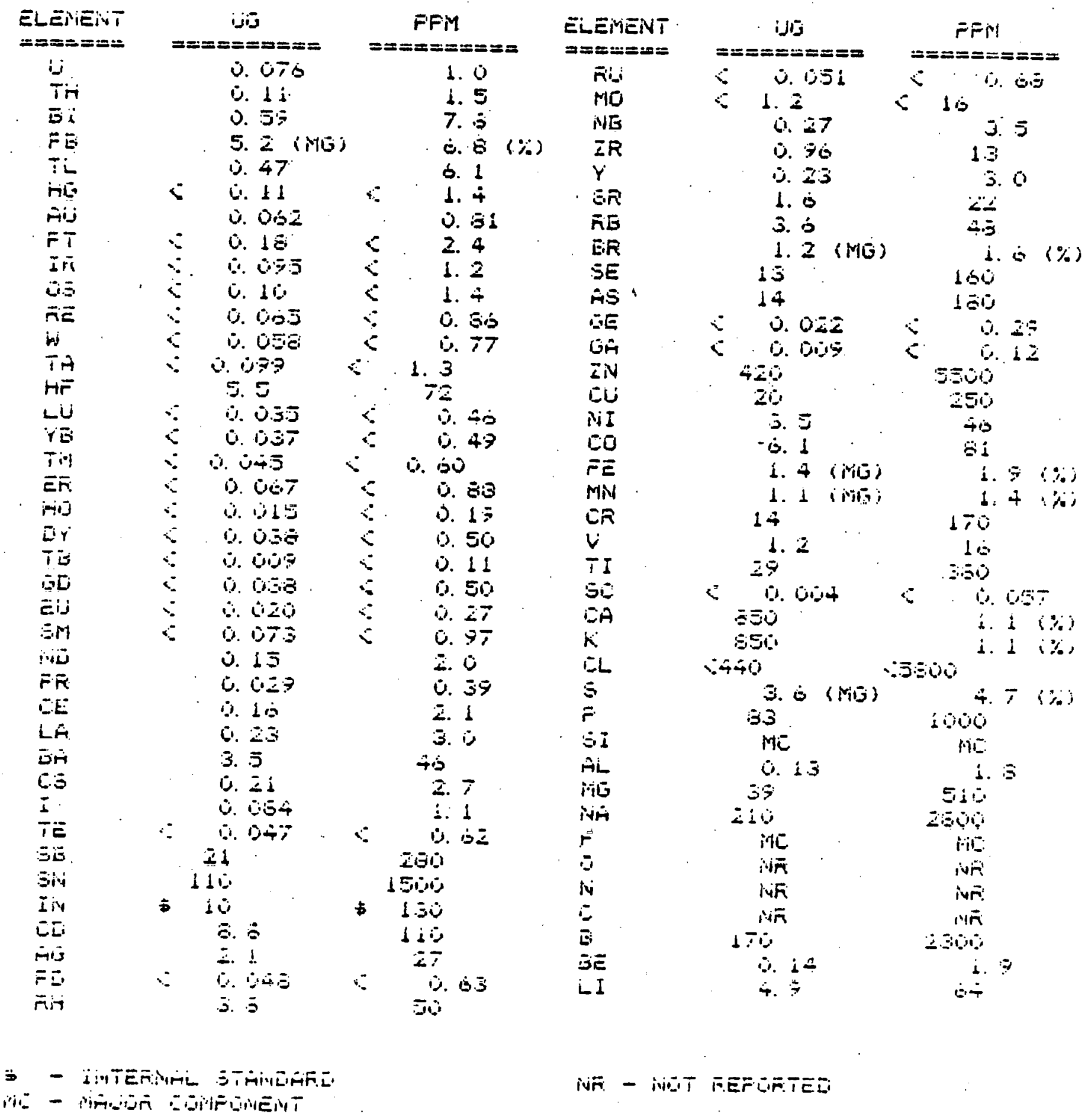




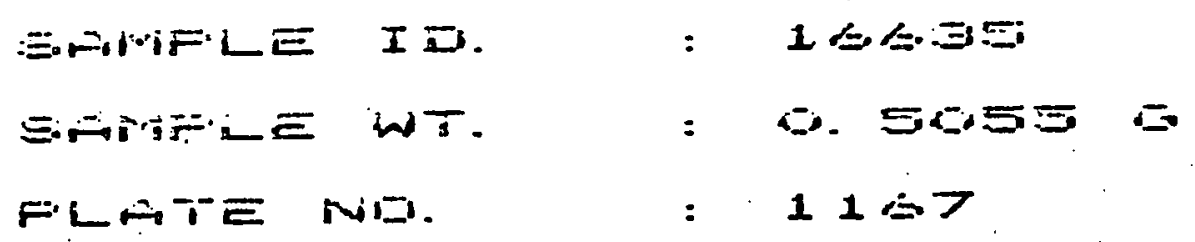

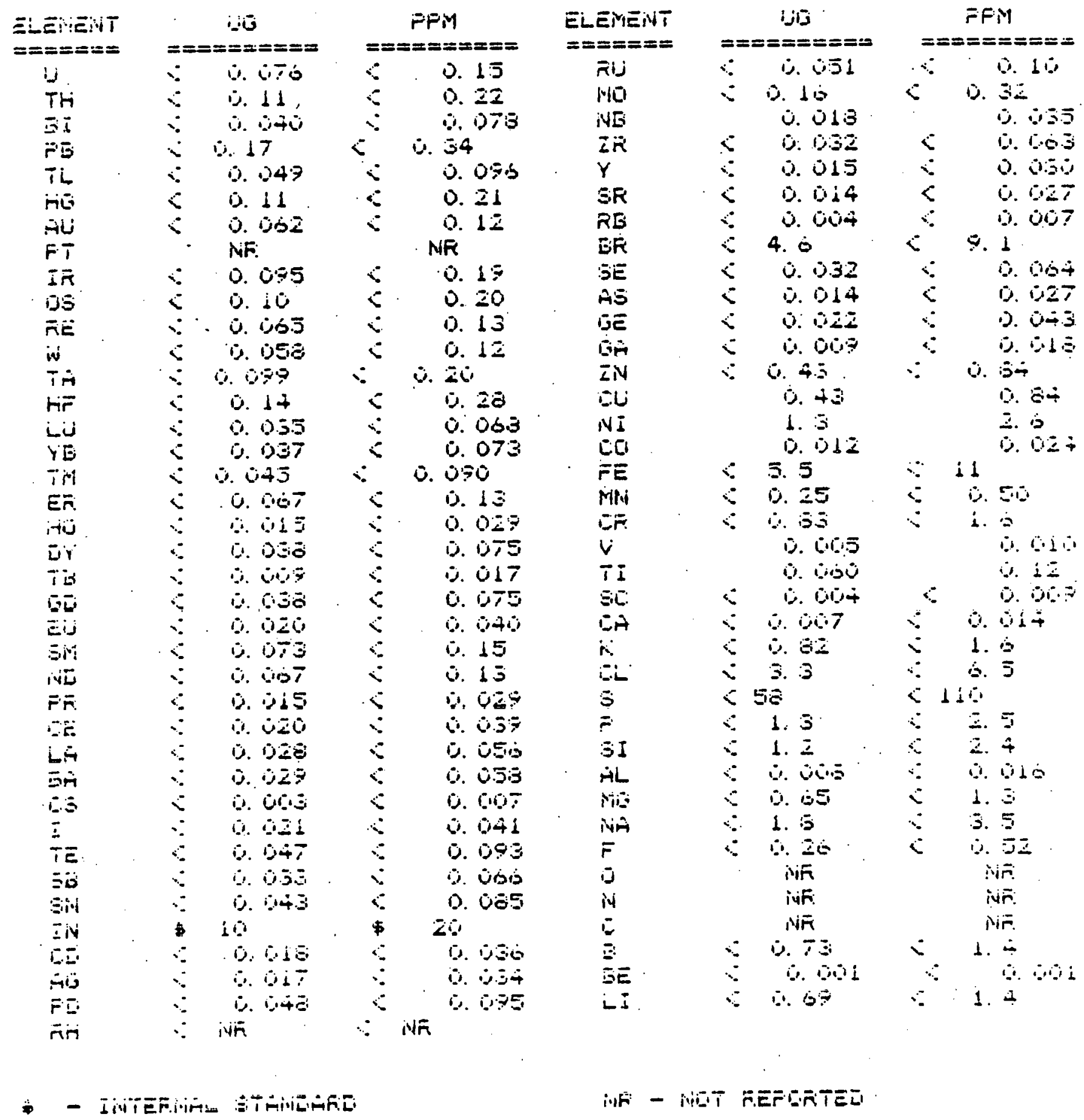


シAMIFLE II. $\Xi \rightarrow M \dot{m}=W T$.

FLATE NE.
$: \quad 1<>\therefore 1$

$=1 \% E$

$: 117$

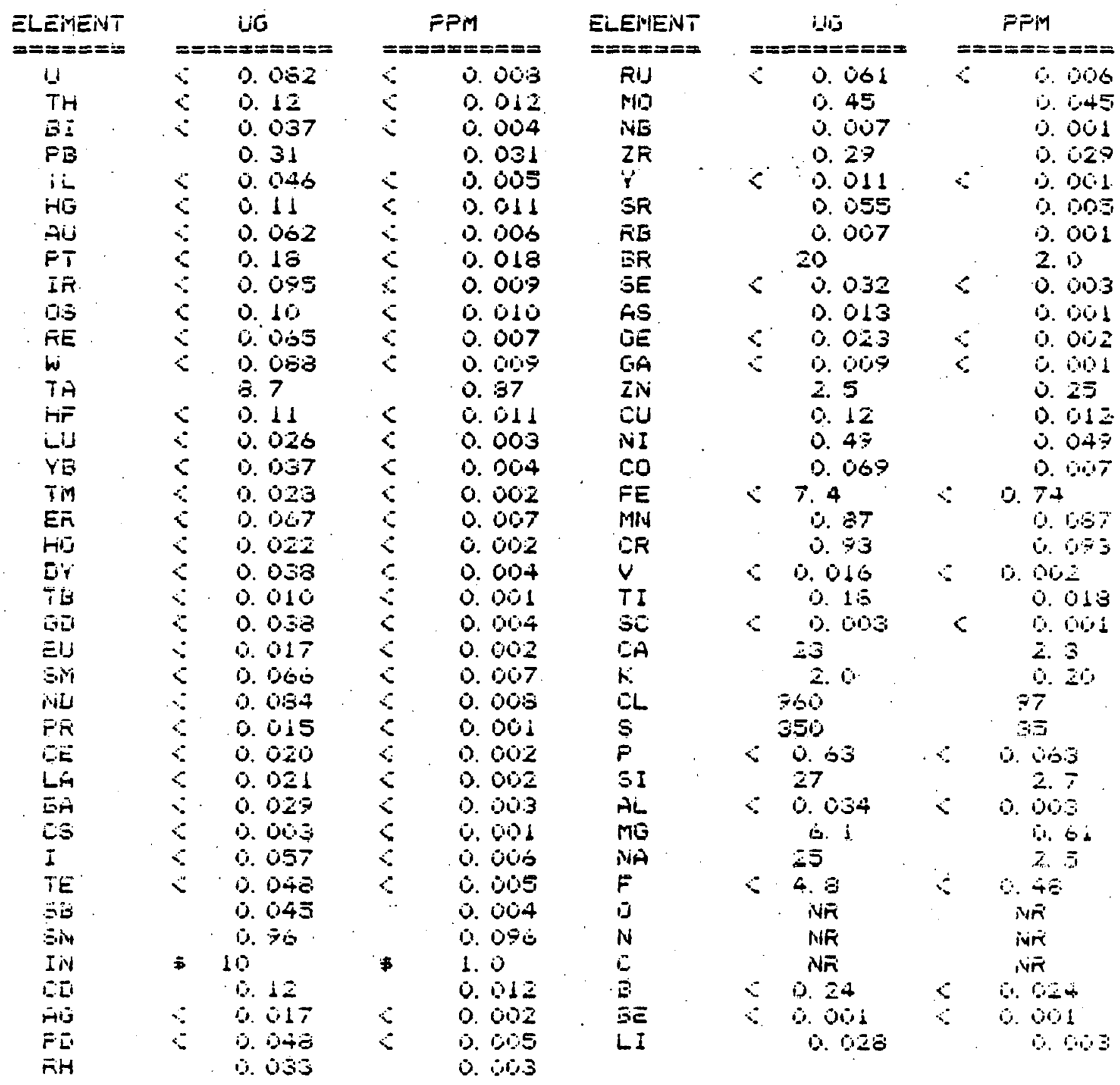




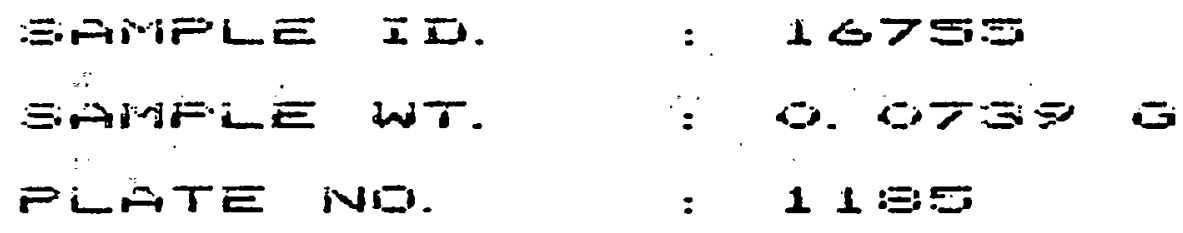

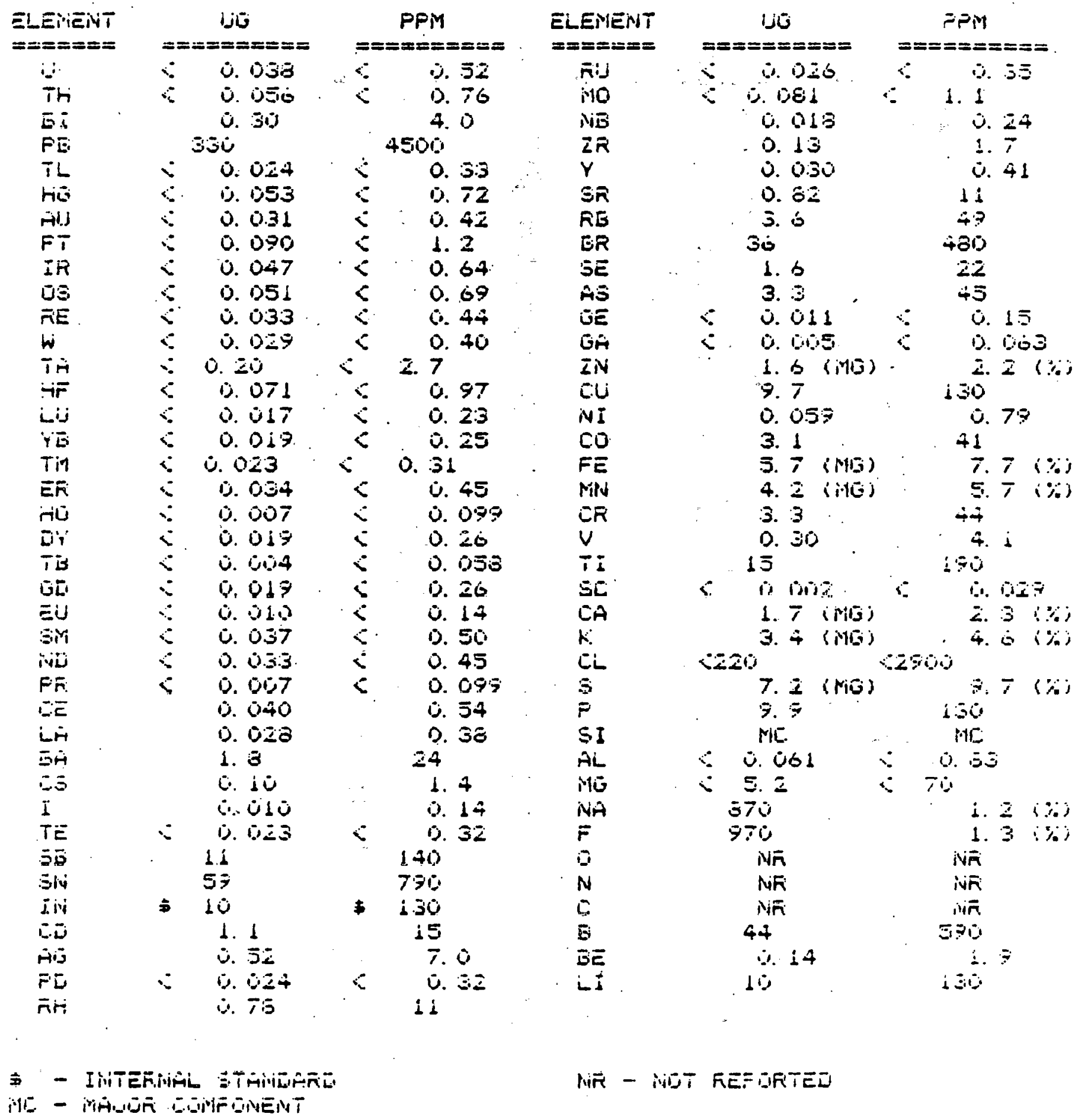




\begin{tabular}{|c|c|c|c|}
\hline 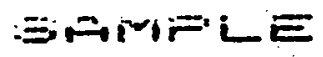 & $\mp \Xi$. & : & $1 . \Delta S: \equiv$ \\
\hline 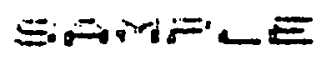 & WT. & : & B. $455=$ \\
\hline
\end{tabular}

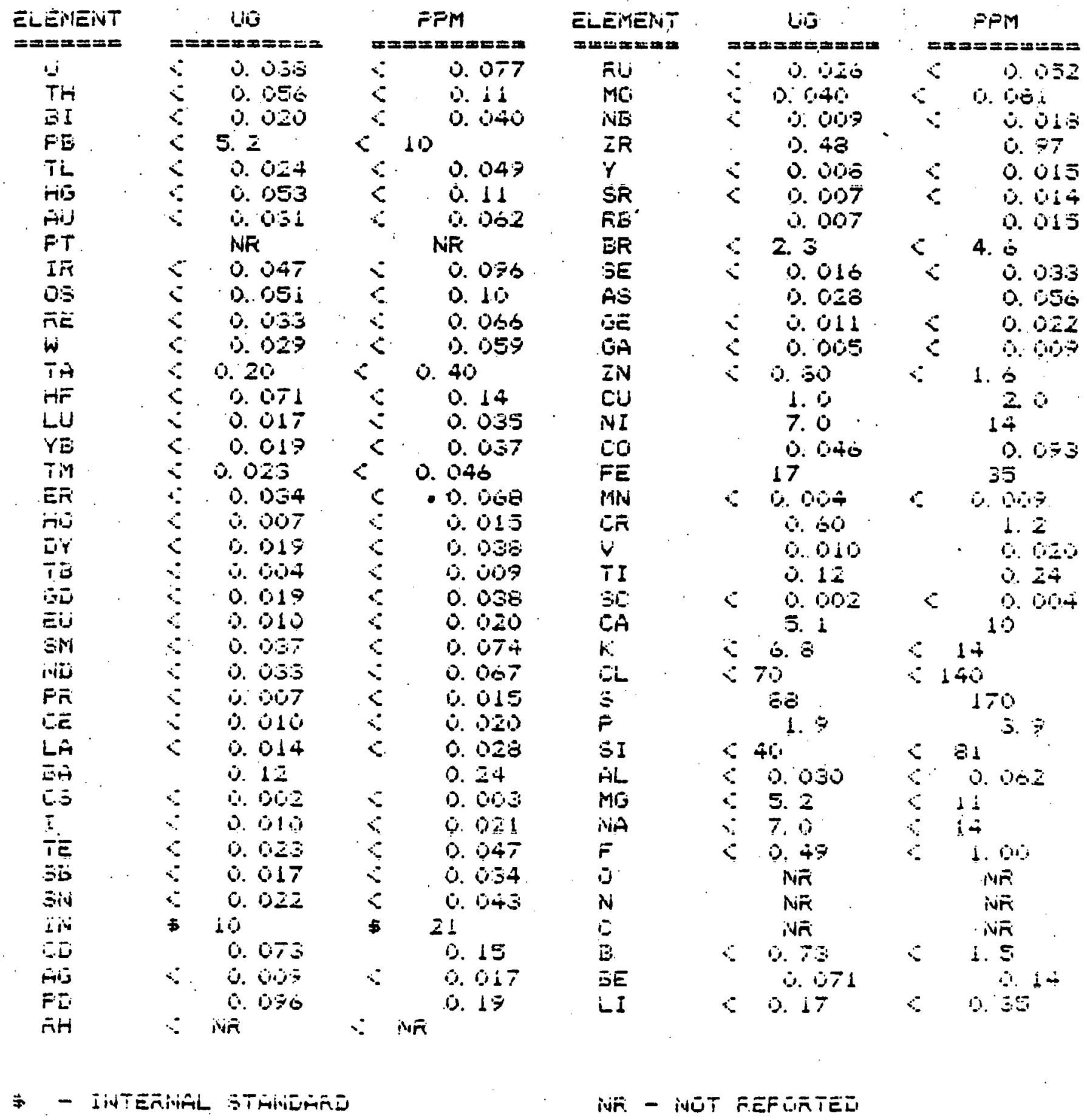




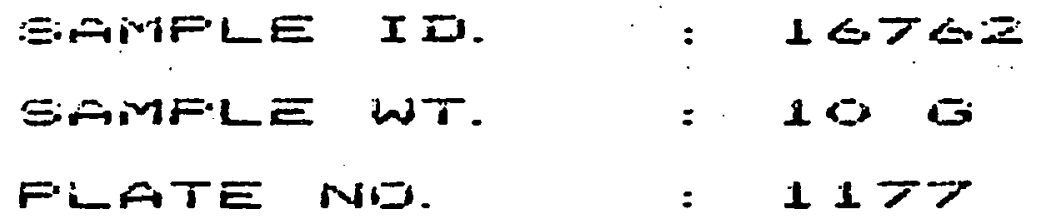

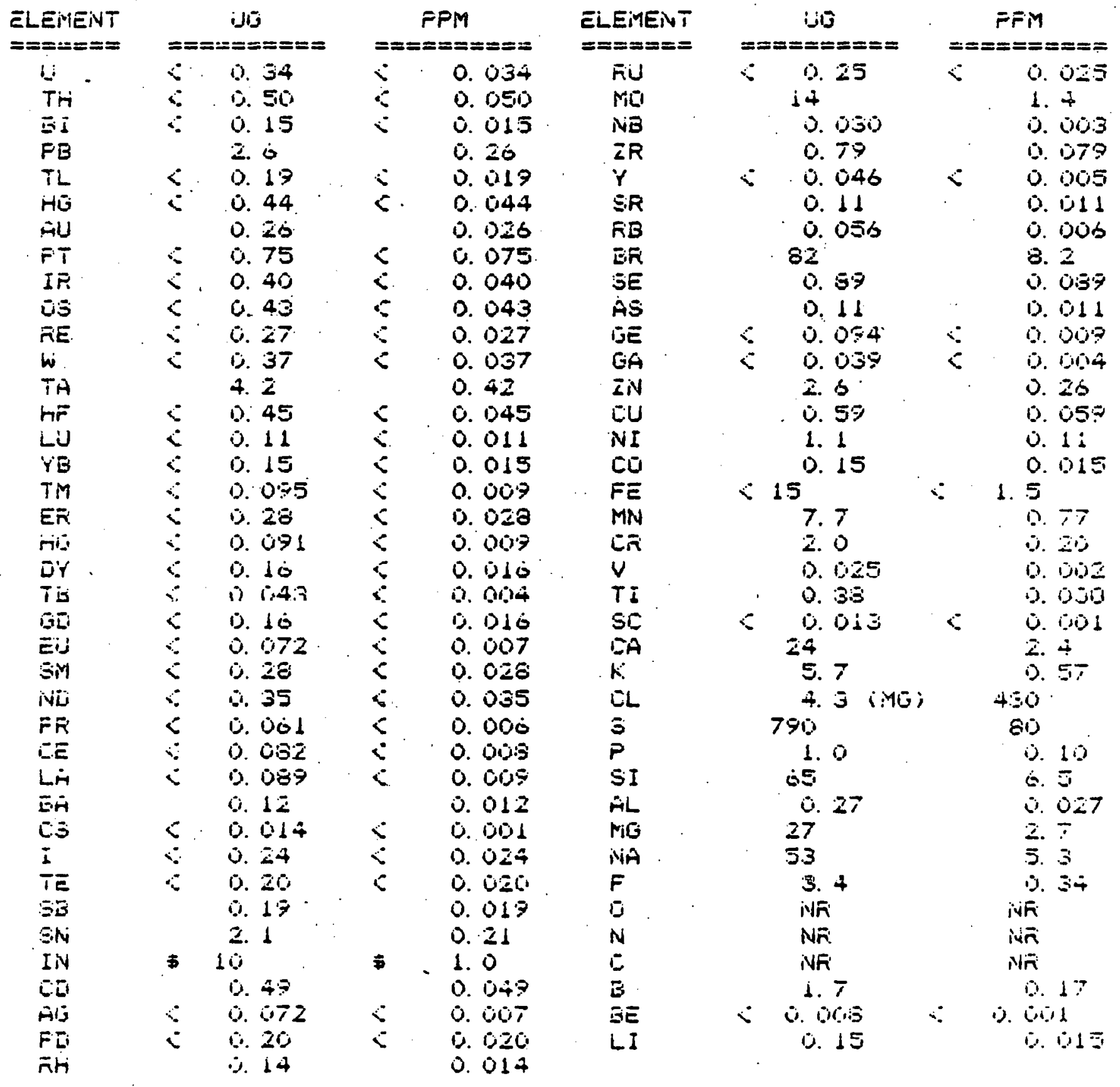


RUN 7 - SAA - FILTER

\begin{tabular}{|c|c|c|c|}
\hline :A円HFLE & $I$ Е. & $:$ & $1 \dot{15 心 ~}$ \\
\hline$\Xi A M=L E$ & $W T$. & : & c.. $\because,\rangle=7$ \\
\hline
\end{tabular}

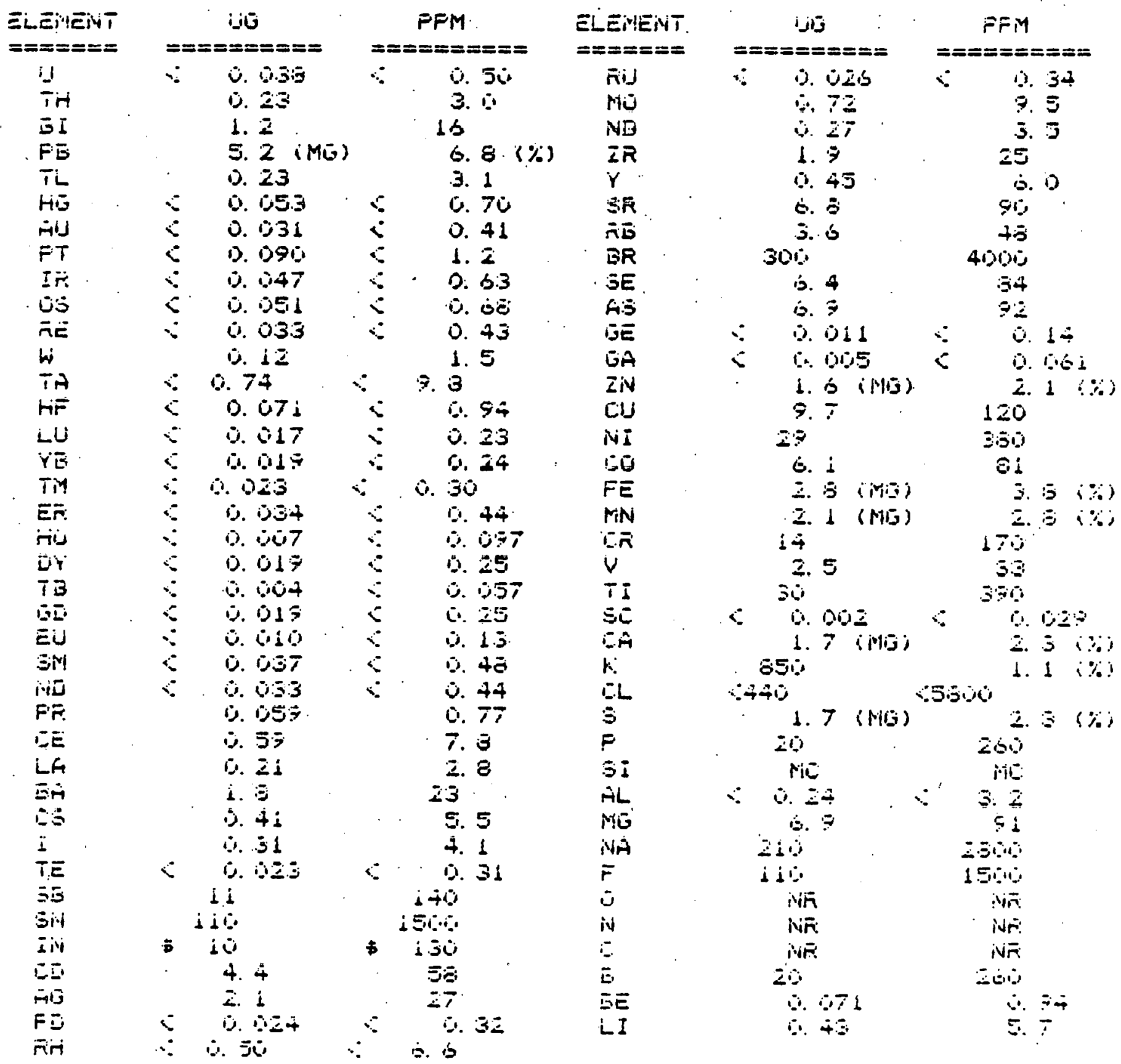




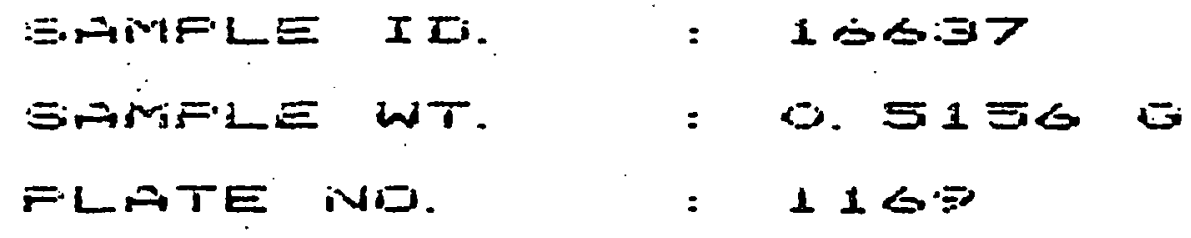

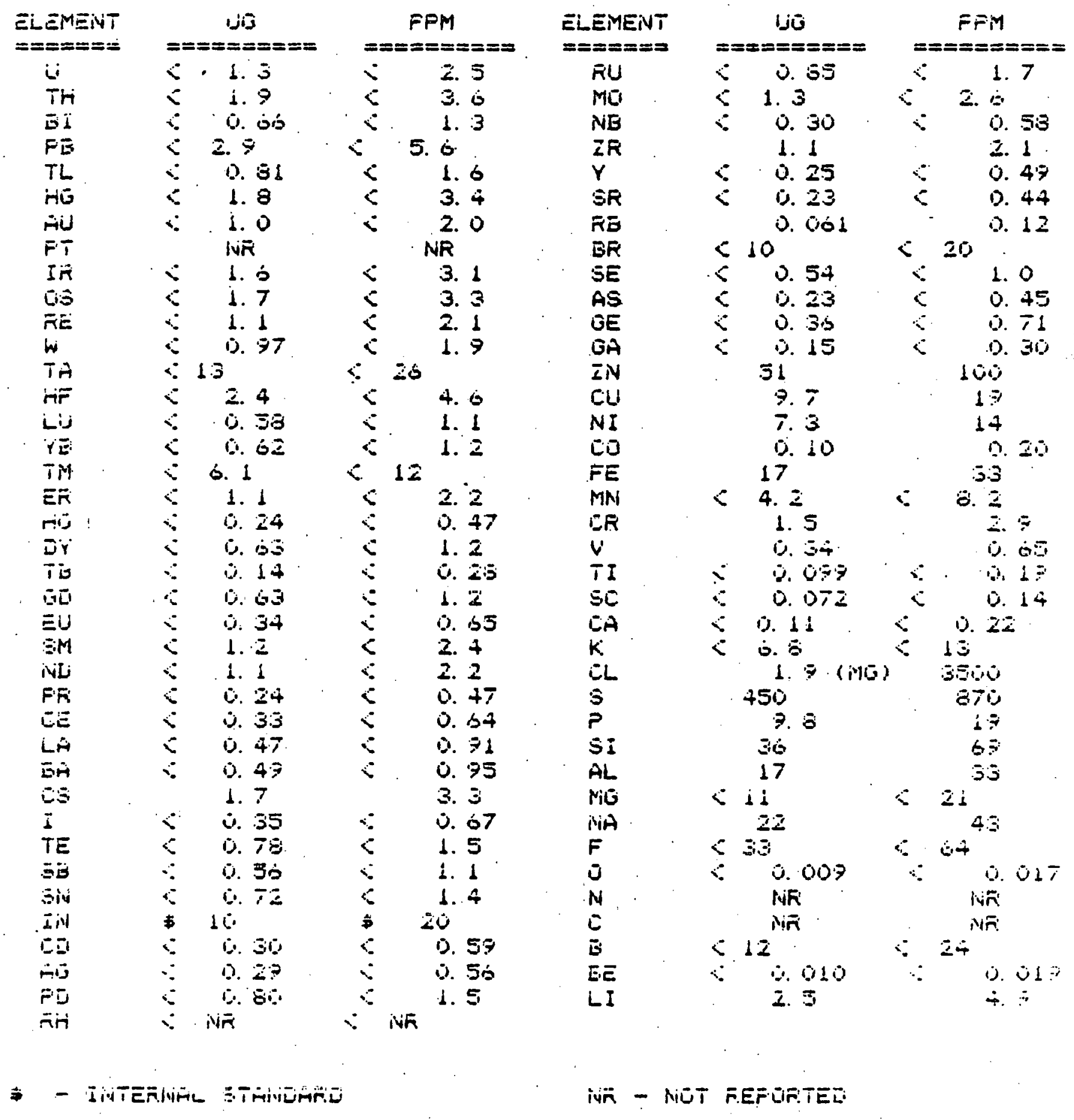




\begin{tabular}{|c|c|c|c|c|}
\hline$\equiv$ GWIF.LLE & $I \pm$. & : & 10 & 5 \\
\hline SAMFLE & adT. & : & 12 & $E$ \\
\hline
\end{tabular}

\begin{tabular}{|c|c|c|c|c|c|c|c|c|}
\hline $\begin{array}{l}\text { ELERIENTT } \\
=======\end{array}$ & $=== \pm======$ & & $\begin{array}{l}=M \\
======\end{array}$ & $\begin{array}{l}\text { ELEITENT } \\
======\end{array}$ & & $=======$ & & $\begin{array}{l}F F M \\
========\end{array}$ \\
\hline 4 & ن. 17 & - & 0.017 & $\bar{n} U$ & $<$ & ن. is & $\dot{\nabla}$ & o. $01:$ \\
\hline 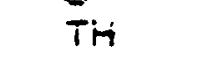 & 0.25 & $\Sigma$ & 0.025 & Mo & & 1.8 & & 0. 10 \\
\hline$\overline{B I}$ & 0. 477 & $<$ & $0.00: 3$ & Nล & $\therefore$ & 0.015 & $\therefore$ & s. 0.11 \\
\hline$F E$ & cs 32 & & D. 0בI & $2 F$ & $<$ & D. 11 & $\therefore$ & 0.011 \\
\hline TL & 0.096 & $<$ & 0.010 & $Y$ & $\therefore$ & 0.023 & $\because$ & 0. 002 \\
\hline$H G$ & $0.2 z$ & 5 & 0. $02 z$ & stR & & D. 1.57 & & Q: \\
\hline Ais & 0. 13 & 5 & 0. 013 & $F E$ & 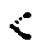 & j. 007 & $<$ & ن. 001 \\
\hline FT & 0.37 & $<$ & 0.037 & BR & & 82 & & b. 2 \\
\hline I.R & 0. 20 & $<$ & o. $0 \geq 0$ & SE & 5 & ن. $\cos 7$ & $\check{-}$ & 0.007 \\
\hline 0.5 & 0. 21 & 5 & 0.021 & $A 5$ & & o. $0 \geq 7$. & & o. 0103 \\
\hline$\overline{R I E}$ & 0.17 & $\therefore$ & 0.014 & GE & $\leqslant$ & 0.047 & $\dot{i}$ & o. $06=$ \\
\hline$\omega$ & 0. 18 & 5 & 0.010 & GÁ & $\Sigma$ & 0. & $\varepsilon$ & 0.00 \\
\hline TA & 7.1 & & 0.71 & LiV & & 2. s & & 0. Is \\
\hline riF & 0. 23 & $<$ & D. $0 \geq 3$ & EL & & 0.20 & & 1). 320 \\
\hline Lis & 0. 0.53 & $<$ & 0.00 .5 & $N \bar{I}$ & & $0.5 i$ & & 0.0151 \\
\hline$Y E$ & s. 077 & $<$ & 0.008 & EO & & 0.010 & & D. 001 \\
\hline$T M$ & o. 047 & 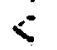 & 0.005 & FE & $<$ & $\div .4$ & $\therefore$ & 15. 74 \\
\hline ER & D. 14 & $<$ & 0.014 & MN & & 1. 9 & & o. 19 \\
\hline nit & o. 045 & $\therefore$ & 0.005 & GR & & 0. 43 & & ن. $0 . \overline{1}$ \\
\hline Tir & $\begin{array}{l}\text { 0. } 1979 \\
0.0 \geq 2\end{array}$ & $\varepsilon$ & $\begin{array}{l}0.008 \\
0.002\end{array}$ & $\begin{array}{l}V \\
T I\end{array}$ & & $\begin{array}{l}6.108 \\
0.1 \%\end{array}$ & & $\begin{array}{l}8.01 \\
0.019\end{array}$ \\
\hline$E$ & $0,0-7$ & $<$ & 0.008 & 50 & 5 & i. 0107 & $<$ & $0.00 i$ \\
\hline EU & 0. $0: 56$ & $\therefore$ & 0.004 & EA & & 12 & & 1. 2 \\
\hline$S M$ & 6.14 & 5 & D. 014 & $k$ & 5 & 3. 0 & $<$ & 0. 36 \\
\hline نَلن & 0.17 & $\check{\perp}$ & 0.017 & $\mathrm{CL}$ & & 1.0 ( $\mathrm{M}(\mathrm{O})$ & & 100 \\
\hline$F F$ & 0.031 & 5 & o. 003 & $S$ & & 390 & & 37 \\
\hline$E E$ & a. 041 & 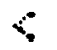 & 0.004 & $p$ & & 0.57 & & $0.05 \%$ \\
\hline LA & 0.1245 & 5 & 0.004 & $3 I$ & & 5. 1 & & 6. 51 \\
\hline$\overline{B A}$ & 0.061 & $<$ & 0. 000 & $A L$ & & Q. 021 & & $\therefore 00 \div$ \\
\hline$E \Xi$ & 3. 4 & & 0.34 & MO & & 13 & & 1.7 \\
\hline I & ¿. 12 & $\because$ & 0.015 & NA & & 20 & & $=5$ \\
\hline TE & 0.099 & $\varepsilon$ & 0.010 & $F$ & 8 & 2. 5 & $<$ & 6.25 \\
\hline 58 & 0.070 & $<$ & 0.007 & i & & ivis & & iNกิ \\
\hline Sivi & b. 27 & & D. $0 \geq 7$ & $N$ & & int & & $N \bar{\pi}$ \\
\hline In & 10 & $\$$ & 1. 0 & $c$ & & $\mathrm{~N} R$ & & NR̃ \\
\hline$E \bar{D}$ & D. 45 & & 0.047 & 5 & 5 & c. $5 \%$ & $\therefore$ & $6.05 i j$ \\
\hline$\ddot{3}$ & ن. J̄śs & $\therefore$ & 0.944 & SEE & $\therefore$ & c. 00 & $\therefore$ & o. $\quad \because 4 i$ \\
\hline PD & D. $i 00$ & 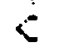 & $0.0 \mathrm{ic}$ & LI & $<$ & 9013 & $\therefore$ & $\theta .92$ \\
\hline $\overrightarrow{F i H}$ & $\therefore \quad \therefore .05$ & $\therefore$ & 0.003 & & & & & \\
\hline
\end{tabular}




\begin{tabular}{|c|c|c|c|c|}
\hline$: \equiv: \approx N$ NIFLE & $I \Sigma$. & : & $i \leqslant 7$ & $\leq 7$ \\
\hline$\Xi \ddot{M}=2 E$ & it. & $\Xi$ & $1<$ & 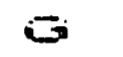 \\
\hline
\end{tabular}

\begin{tabular}{|c|c|c|c|c|c|c|}
\hline $\begin{array}{l}\equiv \text { ELEVIEIVT } \\
======\end{array}$ & $==========$ & $\begin{array}{c}F P M \\
==========\end{array}$ & $\begin{array}{l}\text { ELENHENT } \\
======\end{array}$ & $\begin{array}{c}\mathrm{iU} \\
=========\end{array}$ & & $\begin{array}{l}F P M . \\
=======\end{array}$ \\
\hline$i j$ & ن. & $0 . \sin 9$ & Fid & 0.51 & $\therefore$ & i. 051 \\
\hline Tiri & 1. 00 & ن. 100 & Mo & 3. 47 & $\therefore$ & $\therefore 6+7$ \\
\hline$\Xi \ddot{i}$ & ن. 31 & j. 031 & Nis & 0. 0.57 & $\therefore$ & D. \\
\hline$F \bar{B}$ & 0.64 & D. 064 & $\overline{Z F}$ & 1. 7 & & 0. 17 \\
\hline$T$ & 0. $3 \%$ & 0. 0.37 & $\bar{r}$ & 3.071 & $\therefore$ & ن. 007 \\
\hline His & 0.87 & D. 009 & SR & 0.11 & 5 & jo. 011 \\
\hline تंن & 0.51 & 0.051 & KE & 3. 3 & & j. 33 \\
\hline$F T$ & 1. 5 & 0.15 & ER & 5. 3 & & 0.53 \\
\hline in & 0.77 & ง. 077 & SE & $\dot{0} .27$ & $\therefore$ & ن \\
\hline 05 & $0.80^{\circ}$ & 0.900 & A.S & 0.11 & $\varepsilon$ & a. 018 \\
\hline FE & o. 54 & 0.054 & GE & 0.17 & 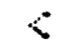 & 0.017 \\
\hline ij & ‥ 73 & 0.073 & GA & 0.078 & $<$ & 2.005 \\
\hline Tì & $\neq 1$ & 0.31 & $\overline{E N}$ & Z. & & ن. 20 \\
\hline iriF & ij. 91 & D. 071 & Ciu & 0. (5) & & c. $00=$ \\
\hline LÚ & o. $Z i$ & 0. 021 & $N I$ & 0.13 & $\therefore$ & $\dot{0} 013$ \\
\hline 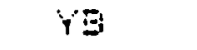 & a. 31 & 0.031 & 20 & D. 030 & $\lessdot$ & D. 0ist \\
\hline TiN & 3. 7 & 0.57 & FE & 1.5 & $\therefore$ & i) 17 \\
\hline En & 0. 5 is & 0. 0si & $M N$ & 0. 0.5 & $<$ & B. \\
\hline تنं & 0.15 & o. 013 & $E \pi$ & i). 25 & & 9025 \\
\hline Eir & 0. 32 & i. 032 & $v$ & 0. 125 & & a 8 \\
\hline כت & i. ن்s & 0.007 & TI & $\dot{G} .7$ & & 0.97 \\
\hline$\pi i$ & 9.32 & 0.032 & $5 i$ & 9.927 & 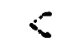 & 6. \\
\hline$E^{i j}$ & $\therefore 1 \overline{4}$ & 0.014 & $E A$ & 0.51 & & - $05:$ \\
\hline Sivi & i. 55 & 1. 055 & $k$. & 3. 4 & 5 & 0.34 \\
\hline ivi & 0.70 & 0.070 & EL & :3. 7 (Mü) & & $E T 0$ \\
\hline$F F$ & C. $1 E$ & ․ 012 & 5 & i. 2 & & $\therefore 6$ \\
\hline$E E$ & 0. 10 & 0.016 & $F$ & 2. 4 & & 0.24 \\
\hline$\dot{L}$ & $0.1 \%$ & 0.0103 & हI & 31 & & 3.1 \\
\hline$E A$ & ن. 24 & 0.024 & $A L$ & 0. 27 & & $\because 0.7$ \\
\hline$\therefore=$ & 3. 027 & D. 003 & Nis & 27 & & $\therefore 7$ \\
\hline$\check{\Xi}$ & 6. 47 & 0. 6.47 & Nì & 28 & & 2.3 \\
\hline TE & 0. +4 & 0.040 & $F$ & 150 & & $8=$ \\
\hline$\equiv \bar{E}$ & $\therefore 25$ & (6. 623 & D & Nก̃ & & ivin \\
\hline$\Xi i l u$ & 0. 35 & 0.039 & iv & inisi & & $\operatorname{lin} \bar{n}$ \\
\hline in & 10 & 1. $\dot{0}$ & $\approx$ & nin & & Vก̃ \\
\hline EL & 0.75 & 0. 047 & 5 & 1. 7 & & $\because 17$ \\
\hline زَّ & 0.17 & $\because \dot{0} 14$ & $\overline{D E}$ & $3: 7$ & & 3.37 \\
\hline $\begin{array}{l}\vec{F}=\overline{1} \\
\vec{n} \bar{H}\end{array}$ & $\begin{array}{l}\because \quad \dot{0} \\
\therefore \quad \dot{0}\end{array}$ & $\begin{array}{l}\text { i. } 040 \\
0119\end{array}$ & $L I$ & $2 . \dot{0}$ & & $\therefore-0$ \\
\hline דוז & 0.17 & & & & & \\
\hline - & $+i \quad 5 T$ & & Puk - & F.EF & & \\
\hline
\end{tabular}




\begin{tabular}{|c|c|c|c|}
\hline 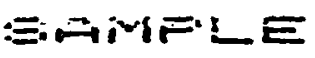 & I I. & : & $1 \leq \Delta: \equiv: \Xi$ \\
\hline BMMFIL & W. & $:$ : & 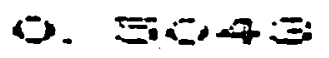 \\
\hline
\end{tabular}

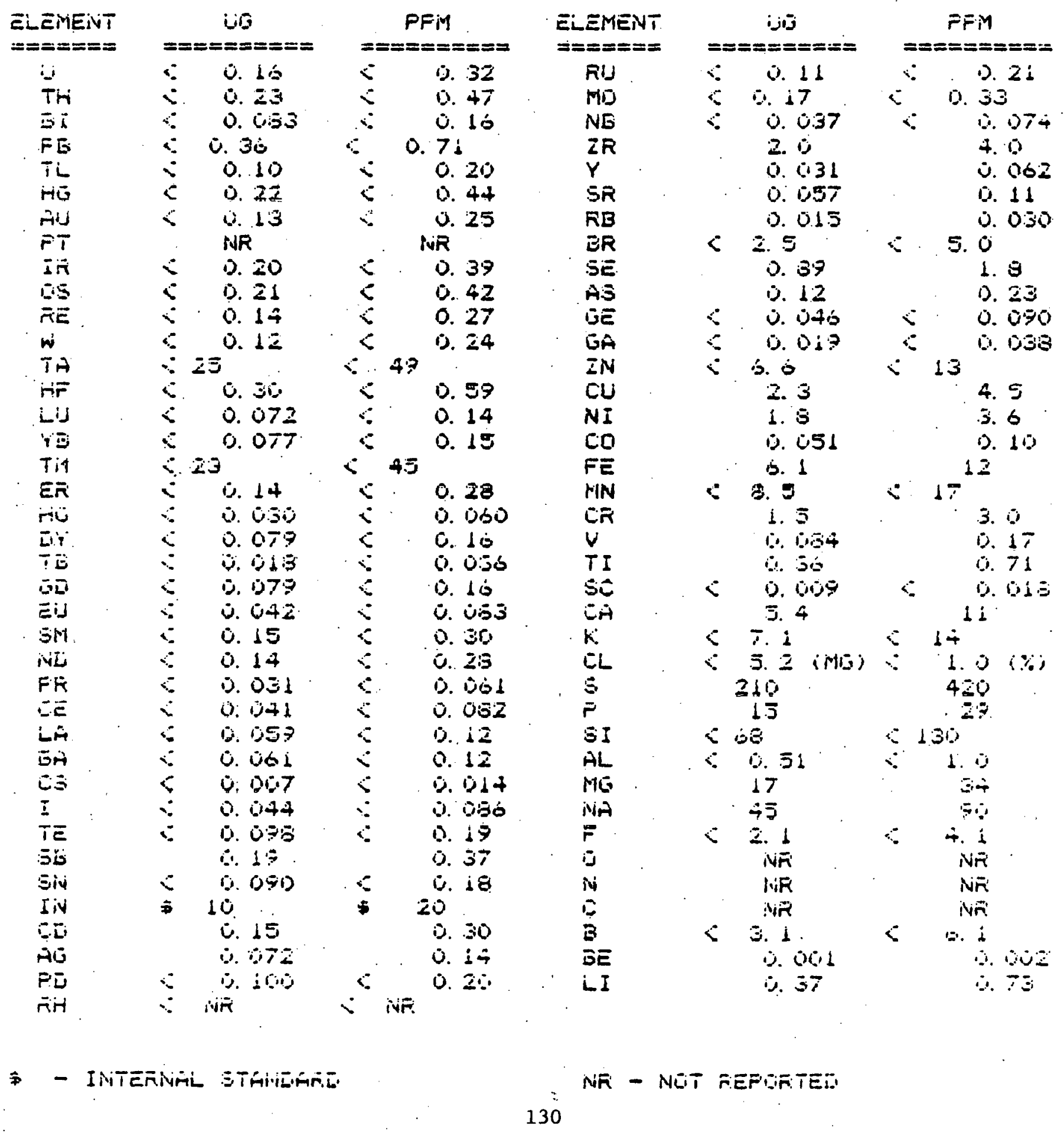




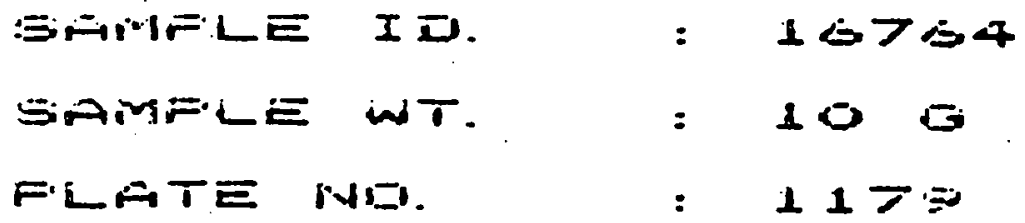

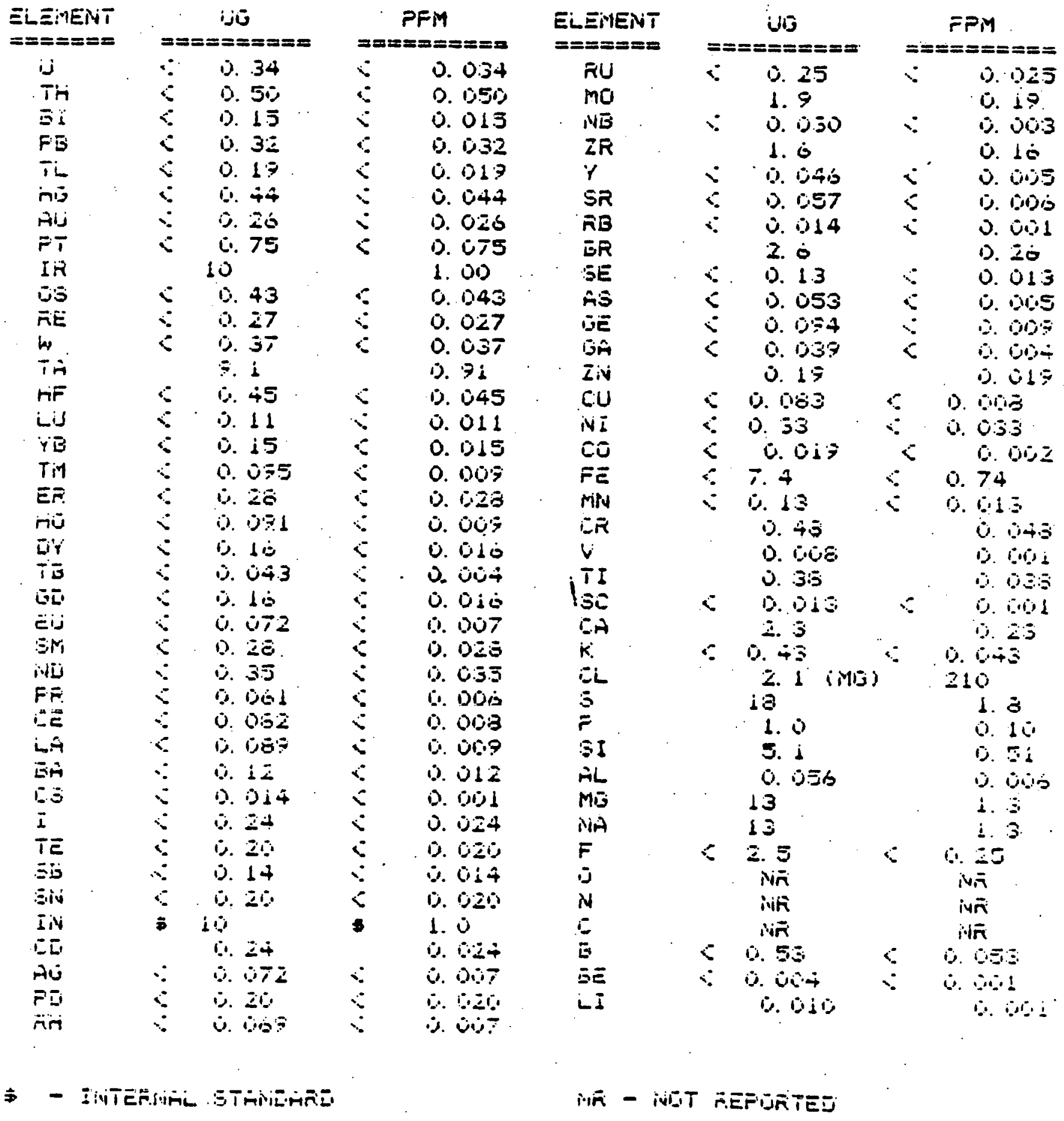




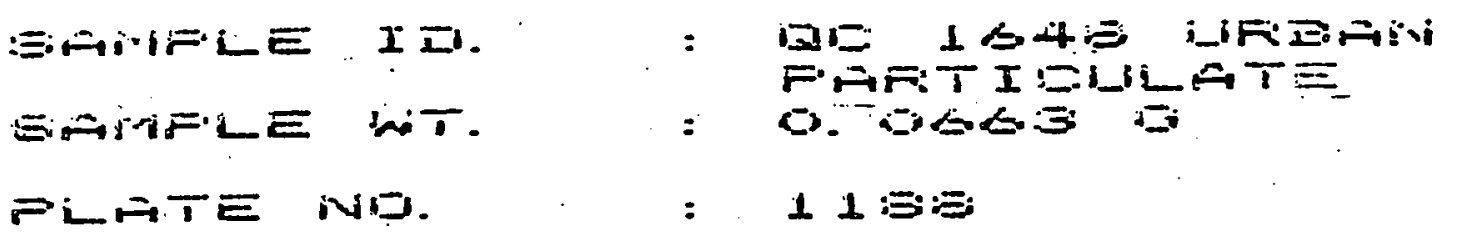

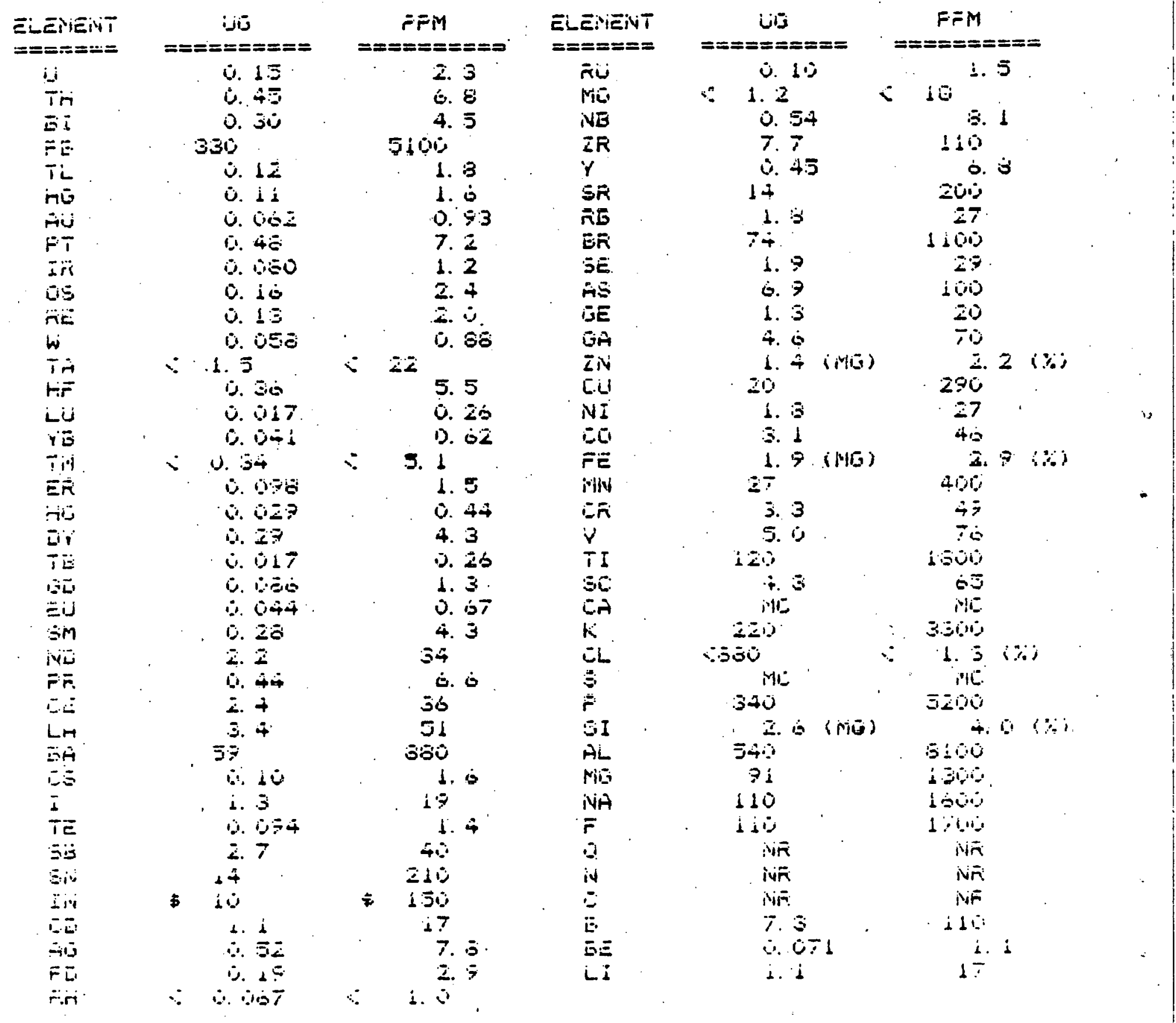

